\title{
UTILIZAÇÃO DE AGENTES ANTIMICROBIANOS, PROBIÓTICOS, PREBIÓTICOS E EXTRATOS VEGETAIS COMO PROMOTORES DO CRESCIMENTO DE LEITÕES RECÉM-DESMAMADOS
}

\section{Carlos EduARdo UtiYAma}

Tese apresentada à Escola Superior de Agricultura "Luiz de Queiroz", Universidade de São Paulo, para obtenção do título de Doutor em Agronomia, Área de Concentração: Ciência Animal e Pastagens.

P I R A C I C A B A

Estado de São Paulo - Brasil

Setembro - 2004 


\section{UTILIZAÇÃO DE AGENTES ANTIMICROBIANOS, PROBIÓTICOS, PREBIÓTICOS E EXTRATOS VEGETAIS COMO PROMOTORES DO CRESCIMENTO DE LEITÕES RECÉM-DESMAMADOS}

\section{Carlos Eduardo Utiyama}

Zootecnista

Orientador: Prof. Dr. VALDOMIRO SHIGUERU MIYADA

Tese apresentada à Escola Superior de Agricultura "Luiz de Queiroz", Universidade de São Paulo, para obtenção do título de Doutor em Agronomia, Área de Concentração: Ciência Animal e Pastagens.

P I R A C I C A B A

Estado de São Paulo - Brasil

Setembro - 2004 


\section{Dados Internacionais de Catalogação na Publicação (CIP) DIVISÃO DE BIBLIOTECA E DOCUMENTAÇÃO - ESALQ/USP}

\section{Utiyama, Carlos Eduardo}

Utilização de agentes antimicrobianos, probióticos, prebióticos e extratos vegetais como promotores do crescimento de leitões recém-desmamados / Carlos Eduardo Utiyama. - - Piracicaba, 2004.

94 p. : il.

Tese (doutorado) - - Escola Superior de Agricultura Luiz de Queiroz, 2004. Bibliografia.

1. Antimicrobiano 2. Crescimento animal 3. Desempenho animal 4. Desmama 5. Extrato vegetal 6. Morfologia animal 7. Prebiótico 8. Probiótico 9. Suíno I. Título

CDD 636.4084 
Aos meus pais,

Seiji e Solange, que representam meu porto seguro, minha origem e minha fonte de dignidade;

Ao meu irmão,

Luis Gustavo, sempre solícito, solidário e companheiro;

Aos meus sogros,

Afonso e Lúcia, exemplos de fé;

Aos meus cunhados,

Luciano, Luciane, Luis Afonso e Daniela, pela amizade e companheirismo;

À sempre querida amiga, Jacinta, pela atenção, conselhos e amizade;

\section{Com muito amor e gratidão,}

Dedico.

À minha querida esposa,

Liliana, companheira incondicional na vida afetiva e profissional;

Ofereço. 


\section{AGRADECIMENTOS}

A Deus;

À CAPES, pela bolsa concedida durante o curso;

À Fundação de Amparo à Pesquisa do Estado de São Paulo - FAPESP, pelo financiamento do projeto de pesquisa, concedido em nome do Prof. Dr. Valdomiro Shigueru Miyada;

Ao Prof. Dr. Valdomiro Shigueru Miyada, pela amizade, orientação e confiança;

Ao Prof. Dr. José Fernando Machado Menten, pelos conselhos, apoio e auxílio;

Ao Prof. Dr. José Eurico Possebon Cyrino, pela amizade e pelos conselhos;

Ao Prof. Dr. Irineu Umberto Packer e a doutoranda Juliana Di Giorgio Giannotti, pelos valiosíssimos conselhos e sugestões no momento da análise dos dados;

À Profa. Dra. Catarina Abdalla Gomide, pela amizade e pelo apoio nas análises bromatológicas;

Ao Prof. Dr. Virgílio F. do Nascimento Filho, responsável pelo Laboratório de Instrumentação Nuclear do CENA/USP, que muito colaborou para as análises laboratoriais;

Ao Prof. Dr. Paulo Chanel, pelos conselhos e orientações na área de farmacognosia;

À Profa. Dra. Maria Inês Ré, responsável pelo Laboratório de Tecnologia de Partículas do IPT/USP, com colaboração vital ao projeto no microencapsulamento dos óleos essenciais;

Ao Prof. Dr. Elliot Watanabe Kitajima, responsável pelo Núcleo de Apoio à Pesquisa/Microscopia Eletrônica Aplicada a Pesquisa Agropecuária da ESALQ/USP, pela contribuição na área de microscopia eletrônica;

Ao Prof. Dr. Nilson Roberti Benites e à Médica Veterinária Priscilla Anne Maelville, responsáveis pelo Laboratório de Doenças Infecciosas - Bactérias e Fungos, do Departamento de Medicina Veterinária Preventiva e Saúde Animal da FMVZ/USP, pela contribuição nas análises microbiológicas;

Ao Prof. Dr. Mário Júlio Ávila Campos, responsável pelo Laboratório de Microbiologia Oral Anaeróbios, do Departamento de Microbiologia do ICB/USP, pelos conselhos e contribuição nas análises de Clostridium perfringens; 
À Dra. Eliana Scarcelli, responsável pelo Laboratório de Doenças Bacterianas da Reprodução no Centro de Pesquisa e Desenvolvimento de Sanidade Animal do Instituto Biológico de São Paulo, pelas análises de Campylobacter coli.

Aos amigos Nilton Pedro dos Santos e Tiago Debem, pela grande contribuição nas análises histológicas;

Aos estagiários e amigos, Pedro Giani e Urbano dos Santos Ruiz, pela amizade e inestimável colaboração na condução dos experimentos;

Aos funcionários do Setor de Suinocultura do Departamento de Zootecnia da ESALQ/USP, Srs. Pires, Leonilço, Galvão, Adão e Paulinho;

Ao funcionário da Fábrica de Rações do Departamento de Zootecnia da ESALQ/USP, Antonio Carlos, pelo auxílio na confecção das dietas experimentais;

Aos demais funcionários do Departamento de Zootecnia da ESALQ/USP, Vera, Henrique, Claudia, José Augusto, Ednézio, Agenor, Otávio, Antonio Carlos, Júnior, Sérgio, Geraldo, Alexandre, José Kossut e Luis Fernando, pela grande ajuda durante todo o curso;

À empresa Supre Mais Ind. e Com. Ltda, pela doação de alguns ingredientes para a produção das dietas experimentais;

À empresa Nutron Alimentos Ltda., pela doação de antibióticos e outros microingredientes das dietas experimentais;

Às empresas MCassab Com. e Ind. Ltda. e APC Inc., pela doação do plasma sanguíneo AP920 e da lactose utilizados no projeto;

À empresa Ajinomoto Biolatina Ind. e Com. Ltda., pela doação dos aminoácidos utilizados na composição das dietas experimentais;

À empresa Sloten do Brasil Ind. e Com. Ltda., pela doação do soro de leite K-10 para confecção das dietas experimentais;

À empresa Alltech do Brasil Agroindustrial Ltda., pelo fornecimento do prebiótico BIO-MOS;

À empresa Givaldan do Brasil Ltda., pelo fornecimento de óleos essenciais utilizados no tratamento com extratos vegetais;

À empresa CHR Hansen Ind. e Com. Ltda., pelo fornecimento do probiótico Bio Plus 2B;

Aos colegas de turma e amigos Adriana Figueiredo, Adriana Pedroso, Aline Racanicci, Andrea José, Flávio Longo, José Otávio Sorbara e Patrícia Pauletti, pelo apoio e amizade durante todo o curso, além do grande e valioso auxílio durante os experimentos;

Aos demais companheiros de Departamento, Itiberê, Juliano, Juliana, Andrea e Geraldo, pelos ótimos momentos de convivência;

Àqueles que de alguma maneira, direta ou indiretamente, contribuíram para a realização deste trabalho, a minha enorme gratidão. 


\section{SUMÁRIO}

Página

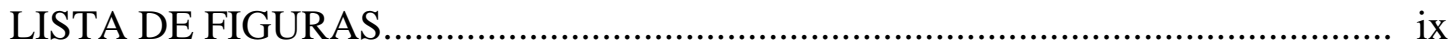

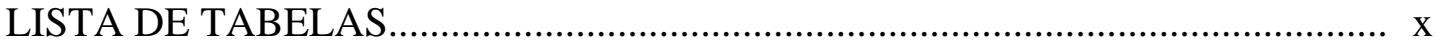

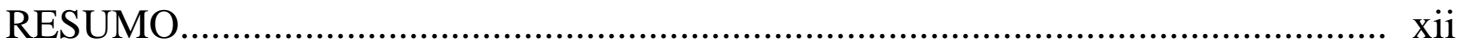

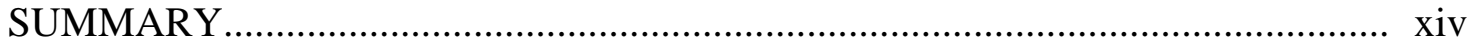

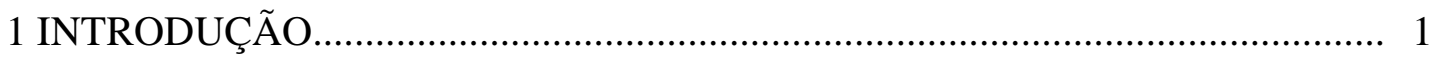

2 REVISÃO DE LITERATURA................................................................. 3

2.1 Morfofisiologia do aparelho digestório de leitões recém-desmamados.......... 3

2.2 Microingredientes promotores do crescimento........................................ 5

2.3 Microingredientes antimicrobianos........................................................ 6

2.3.1 Modos de ação dos microingredientes antimicrobianos.............................. 6

2.3.1.1 Efeito dos antimicrobianos na economia de nutrientes............................... 7

2.3.1.2 Efeito protetor dos antimicrobianos contra a produção de toxinas................. 8

2.3.1.3 Efeito dos antimicrobianos no controle de doenças subclínicas..................... 8

2.3.1.4 Efeito metabólico dos antimicrobianos................................................... 9

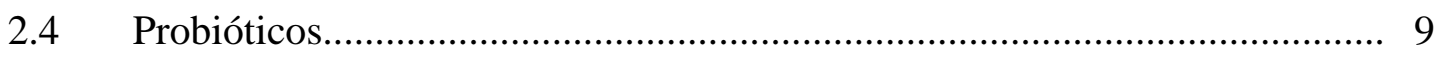

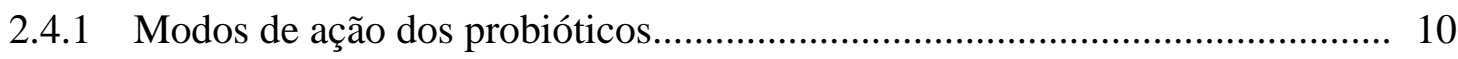

2.4.1.1 Efeito de exclusão competitiva dos probióticos.......................................... 11

2.4.1.2 Efeito de antagonismo direto dos probióticos............................................ 12

2.4.1.3 Efeito dos probióticos sobre o sistema imunológico..................................... 12

2.4.1.4 Efeito nutricional dos probióticos.............................................................. 13

2.4.1.5 Supressão da produção de amônia e neutralização de enterotoxinas pelos

probióticos................................................................................... 14

2.5 Prebióticos (mananoligossacarídeos)....................................................... 14

2.5.1 Modos de ação dos mananoligossacarídeos.............................................. 15 
2.5.1.1 Ação direta dos mananoligossacarídeos sobre a microflora......................... 15

2.5.1.2 Efeito indireto dos mananoligossacarídeos sobre a microflora..................... 16

2.5.1.3 Efeito dos mananoligossacarídeos sobre a morfohistologia intestinal e digestibilidade dos nutrientes................................................................ 16

2.5.1.4 Efeito dos mananoligossacarídeos sobre a imunologia.............................. 17

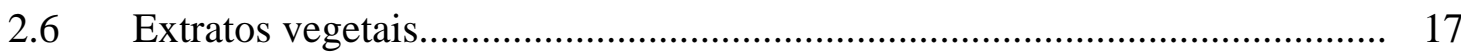

2.6.1 Modos de ação dos extratos vegetais....................................................... 19

2.6.1.1 Efeito antimicrobiano dos extratos vegetais............................................. 19

2.6.1.2 Efeito antioxidante dos extratos vegetais................................................ 21

2.6.1.3 Efeito dos extratos vegetais sobre a digestibilidade.................................... 22

2.6.1.4 Outros efeitos dos extratos vegetais........................................................ 23

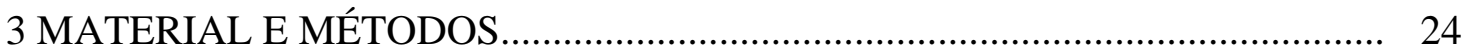

3.1 Instalações e animais..................................................................... 24

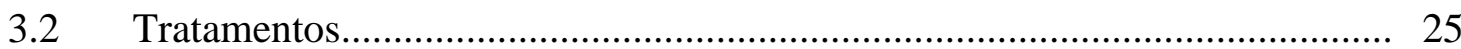

3.2.1 Preparo e caracterização do extrato vegetal............................................. 26

3.2.2 Testes de aceitabilidade/consumo......................................................... 27

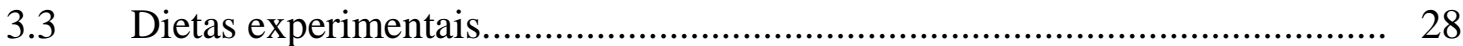

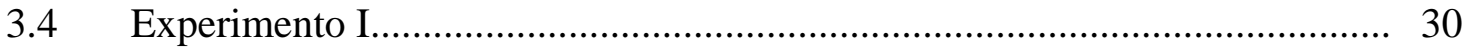

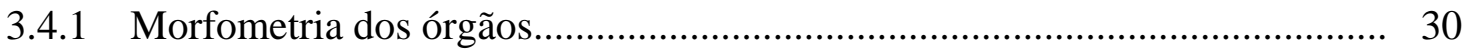

3.4.2 Histologia do epitélio intestinal.......................................................... 30

3.4.2.1 Microscopia óptica........................................................................... 30

3.4.2.2 Microscopia eletrônica de varredura...................................................... 31

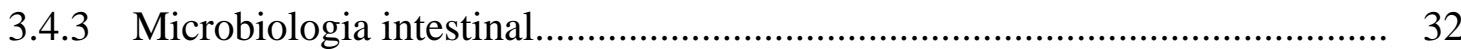

3.4.4 Digestibilidade aparente dos nutrientes................................................. 33

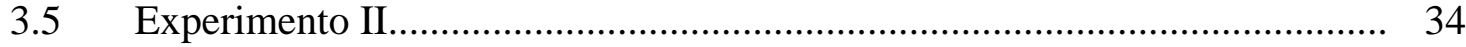

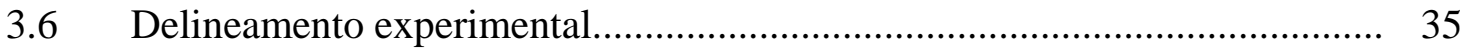

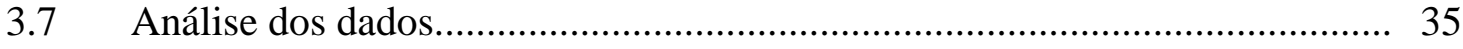

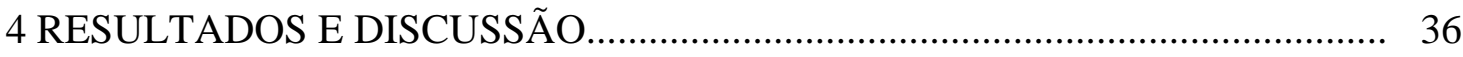

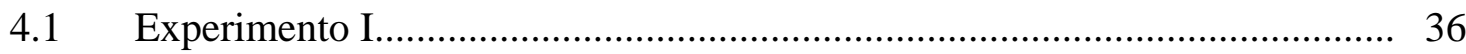

4.1.1 Morfometria dos órgãos....................................................................... 36

4.1.2 Histologia do epitélio intestinal......................................................... 39

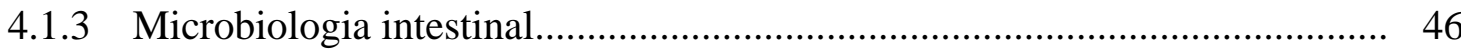

4.1.4 Digestibilidade dos nutrientes.............................................................. 49

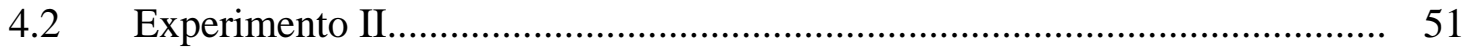




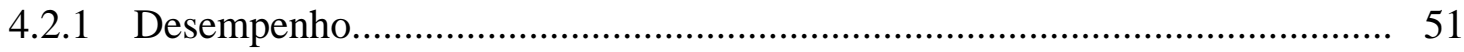

4.2.2 Frequência de diarréia...................................................................... 58

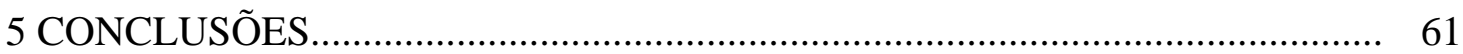

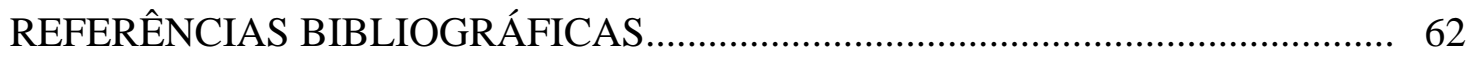

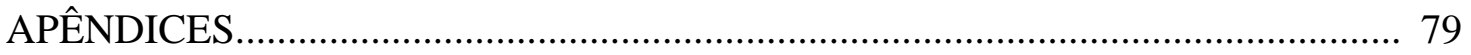




\section{LISTA DE FIGURAS}

Página

1 Croqui da creche experimental do Setor de Suinocultura do Departamento de Zootecnia da ESALQ/USP

2 Eletronmicrografias de varredura do duodeno dos leitões dos tratamentos controle (C), antimicrobiano (A), probiótico (PO), prebiótico (PE) e extrato vegetal (E) aos 35 dias de experimentação..............................................................................

3 Eletronmicrografias de varredura do jejuno dos leitões dos tratamentos controle (C), antimicrobiano (A), probiótico (PO), prebiótico (PE) e extrato vegetal (E) aos 35 dias de

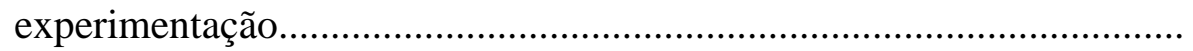

4 Eletronmicrografias de varredura do íleo dos leitões dos tratamentos controle (C), antimicrobiano (A), probiótico (PO), prebiótico (PE) e extrato vegetal (E) aos 35 dias de experimentação............................................................................ 


\section{LISTA DE TABELAS}

Página

1 Proporção das substâncias componentes na emulsão.......................... 26

2 Concentração das substâncias componentes do extrato vegetal na dieta, considerando a inclusão de 500 ppm de extrato vegetal.............. 27

$3 \quad$ Resultados do teste 1 de aceitabilidade/consumo.............................. 27

$4 \quad$ Resultados do teste 2 de aceitabilidade/consumo ............................. 28

$5 \quad$ Composição percentual e valores calculados das dietas basais.............. 29

6 Médias dos pesos relativos (percentagem do peso vivo) dos órgãos digestórios e não digestórios, assim como do comprimento, do comprimento relativo e da relação peso:comprimento do intestino delgado, em função dos tratamentos (Experimento I)...........................

7 Médias da altura das vilosidades (AV), da profundidade das criptas (PC), da relação altura de vilosidade/profundidade de cripta (AV/PC), da percentagem de área ocupada pelas células caliciformes nos epitélios intestinais (\%CC) e da densidade de vilosidades (DV) no duodeno, jejuno e íleo dos leitões ao final de 35 dias de experimentação (Experimento I) 
8 Médias de microrganismos totais, gram positivos totais, gram negativos totais, Bacillus spp. e Escherichia coli no conteúdo do jejuno/íleo, em função dos tratamentos (Experimento I).......................

9 Médias dos coeficientes de digestibilidade aparente para matéria seca, energia bruta e proteína bruta, em função dos tratamentos....................

10 Médias de peso vivo (PV14) aos 14 dias de experimentação e consumo diário de ração (CDR 1-14), ganho diário de peso (GDP 114) e conversão alimentar (CA 1-14) para o período de um a 14 dias de experimentação.

11 Médias de peso vivo (PV 35) aos 35 dias de experimentação e consumo diário de ração (CDR 15-35), ganho diário de peso (GDP 15-35) e conversão alimentar (CA 15-35) para o período de 15 a 35 dias de experimentação..........................................................................

12 Médias de consumo diário de ração (CDR 1-35), ganho diário de peso (GDP 1-35) e conversão alimentar (CA 1-35) para o período de um a 35 dias de experimentação

13 Médias de frequência de diarréia (MFD, \%) e média transformada (MT) para os períodos de um a 14, 15 a 35 e um a 35 dias de experimentação 


\title{
UTILIZAÇÃO DE AGENTES ANTIMICROBIANOS, PROBIÓTICOS, PREBIÓTICOS E EXTRATOS VEGETAIS COMO PROMOTORES DO CRESCIMENTO DE LEITÕES RECÉM-DESMAMADOS
}

\author{
Autor: CARLOS EDUARDO UTIYAMA \\ Orientador: Prof. Dr. VALDOMIRO SHIGUERU MIYADA
}

\section{RESUMO}

O objetivo do trabalho foi estudar os efeitos de probióticos, prebióticos e extratos vegetais como alternativas ao uso de agentes antimicrobianos como promotores do crescimento de leitões recém-desmamados, por meio da morfologia de órgãos, frequência de diarréia, microbiologia intestinal, histologia de epitélio intestinal, digestibilidade dos nutrientes e desempenho. Foram realizados dois experimentos em blocos casualizados, nos quais foram testados cinco tratamentos: controle - ração basal; antimicrobiano - basal com 50 ppm de bacitracina de zinco + 50 ppm de olaquindox; probiótico - basal com 1300 ppm de probiótico à base de Bacillus subtilis e Bacillus licheniformis; prebiótico - basal com 3000 ppm de mananoligossacarídeo; extrato vegetal - basal com 500 ppm de extrato vegetal (alho, cravo, canela, pimenta, tomilho, cinamaldeído e eugenol). No Experimento I utilizaram-se 40 leitões desmamados aos 21 dias de idade, distribuídos a 20 gaiolas suspensas com dois leitões (um macho castrado e uma fêmea) em cada gaiola (unidade experimental) e quatro repetições por tratamento. Durante a última semana do período experimental foi realizado o ensaio de digestibilidade dos nutrientes, por meio da metodologia da coleta parcial de fezes, tendo o óxido 
crômico $\left(\mathrm{Cr}_{2} \mathrm{O}_{3}\right)$ como marcador. Ao $35^{\circ}$ dia, um animal de cada unidade experimental foi abatido para a coleta de dados referentes à morfometria de órgãos, de amostras do epitélio intestinal para análise histológica e de amostras do conteúdo do jejuno/íleo para análise microbiológica. No Experimento II, foram utilizados 120 leitões desmamados aos 21 dias de idade, alocados em 60 baias com dois animais (um macho castrado e uma fêmea) por baia (unidade experimental), perfazendo 12 repetições por tratamento. As variáveis de consumo diário de ração, ganho diário de peso e conversão alimentar foram coletadas e analisadas nos períodos de 1-14, 15-35 e 1-35 dias de experimentação. Também foi avaliada a frequência de diarréia. Apesar da diferença não ser significativa $(\mathrm{P}>0,05)$, em valores numéricos, os agentes antimicrobianos melhoraram o ganho diário de peso nos períodos de 15-35 (+22\%) e 1-35 $(+21,4 \%)$ dias de experimentação. Também melhoraram $(\mathrm{P}<0,05)$ a digestibilidade aparente de nutrientes $(\mathrm{P}<0,05)$ em relação ao tratamento controle. O prebiótico mananoligossacarídeo foi a melhor alternativa aos antimicrobianos, proporcionando um ganho diário de peso, numericamente $(\mathrm{P}>0,05), 25,7 \%$ superior ao tratamento controle e equivalente ao tratamento antimicrobiano, nos primeiros 14 dias de experimentação. Entretanto, o prebiótico mananoligossacarídeo não melhorou a conversão alimentar $(\mathrm{P}>0,10)$. Nos períodos de 15-35 dias e no período total, o desempenho dos animais do tratamento prebiótico foi intermediário entre o tratamento controle e antimicrobiano. O probiótico não melhorou o desempenho $(\mathrm{P}>0,10)$ e não proporcionou nenhuma alteração nas outras variáveis estudadas. Os extratos vegetais aumentaram o peso relativo do pâncreas $(\mathrm{P}<0,05)$ e melhoraram a digestibilidade aparente da matéria seca da dieta $(\mathrm{P}<0,05)$. No entanto, os extratos vegetais não melhoraram $(\mathrm{P}>0,10)$ o desempenho dos leitões. 


\title{
ANTIMICROBIAL AGENTS, PROBIOTICS, PREBIOTICS AND HERBAL EXTRACTS AS GROWTH PROMOTERS OF WEANLING PIGS
}

\author{
Author: CARLOS EDUARDO UTIYAMA \\ Adviser: Prof. Dr. VALDOMIRO SHIGUERU MIYADA
}

\section{SUMMARY}

The purpose of this work was to evaluate the probiotics, prebiotics and herbal extracts as alternatives to antimicrobial agents as growth promoters of weanling pigs, based on the morphometry of organs, fecal score, intestinal microbiology, intestinal histology, nutrient digestibility and performance. Two randomized complete block design experiments were carried out to compare five treatments: control - basal diet; antimicrobial - basal diet plus Zn bacitracin and olaquindox (50 ppm of each); probiotic - basal diet plus $1300 \mathrm{ppm}$ of probiotic (Bacillus subtilis and Bacillus licheniformis); prebiotic - basal diet plus 3000 ppm of mannanoligosaccharide; herbal extract - basal diet plus 500 ppm of herbal extract (garlic, clove, cinnamon, pepper, thyme, cinnamaldehyde and eugenol). In Experiment I, forty 21-d-weaned pigs were alloted to 20 suspended pens, with two pigs (a barrow and a gilt) per pen (experimental unit) and four replications per treatment. In the last week, the digestibility assay was carried out, using the method of the partial faeces collection, with the chromium oxide $\left(\mathrm{Cr}_{2} \mathrm{O}_{3}\right)$ as fecal marker. On $35^{\text {th }}$ day, an animal of each experimental unit was slaughtered to collect the morphometry data, the intestinal epithelium samples for histological analysis, and the content of the jejunum/ileum for microbiological analysis. In Experiment II, one hundred and twenty 21-d-weaned pigs were used, with 12 replications per treatment and two animals (a 
barrow and a gilt) per experimental unit. The daily feed intake, the average daily gain and the feed conversion were analyzed for 1-14, 15-35 and 1-35 days of experimental periods. The fecal score was also evaluated. Although not significant ( $\mathrm{P}>.05)$, the antimicrobial agents improved the average daily gain of weanling pigs, during 1-35 (+21.4\%) and 15-35 (+22\%) days of experimental periods, compared to pigs fed control diet. The nutrient apparent digestibility of pigs fed antimicrobial were higher $(\mathrm{P}<.05)$ than of those fed control. The prebiotic mannanoligosaccharide showed to be the most efficient alternative to antimicrobials. The average daily gain of pigs fed mannanoligosaccharide was, in numerical values $(\mathrm{P}<.05), 25.7 \%$ higher than of those fed control $(\mathrm{P}>.05)$ and similar $(\mathrm{P}>.05)$ to the animals of the antimicrobial treatment, during 1-14 days of experimental period. However, the feed conversion was not improved ( $\mathrm{P}>.10)$. During 15-35 and 1-35 days of experimental periods, the performance of animals fed mannanoligosaccharide was intermediate between of those fed control and antimicrobial diet. The probiotic did not improve the growth performance of pigs $(\mathrm{P}>.10)$ and did not cause any effect. The herbal extracts increased the relative weight of pancreas $(\mathrm{P}<.10)$ and improved the dry matter apparent digestibility of the diet $(\mathrm{P}<.05)$, compared to control treatment. However, the herbal extracts did not improve pig performance $(\mathrm{P}>.10)$ in any period. 


\section{INTRODUÇÃO}

A população humana mundial deve chegar aos nove bilhões até o ano de 2023 (FAO, 2004a), criando uma demanda por alimentos cada vez maior. No entanto, a sociedade moderna exige, de forma cada vez mais intensa, que os alimentos apresentem qualidade, custo acessível e, acima de tudo, segurança. Além disso, há ainda uma grande preocupação de que esses alimentos não sejam produzidos às custas do uso exacerbado ou do esgotamento dos recursos naturais.

Esse quadro mundial traz um grande desafio às cadeias agroindustriais de alimentos, em especial, à cadeia da carne suína, responsável por mais de $40 \%$ da produção de carne no mundo (FAO, 2004b). Nas últimas décadas, a produção de carne suína vem sendo intensificada por avanços significativos nas áreas da genética, nutrição, ambiência, reprodução, etc. Especificamente, dentro da área de nutrição, os promotores do crescimento antimicrobianos (antibióticos e quimioterápicos) foram fundamentais, trazendo grandes benefícios em termos desempenho e eficiência alimentar, quando utilizados em doses subterapêuticas como microingredientes nas dietas.

Apesar da comprovada capacidade de aumentar o desempenho de suínos, o uso de antimicrobianos, como promotores do crescimento, vem sendo sensivelmente restringido. No Brasil, a clortetraciclina, a oxitetraciclina, a penicilina (Portaria DAS/MA N 159 de 23 de junho de 1992), a nitrofurazona, a furazolidona, o cloranfenicol (Portaria DAS/MA No 448 de 10 de setembro de 1998), a avoparcina (Portaria SVS/MS N 819 de 16 de outubro de 1998), os arsenicais, antimoniais (Portaria SARC/MAPA $N^{\circ} 031$ de 29 de janeiro de 2002), o cloranfenicol e os nitrofuranos (Instrução Normativa MAPA N 38 de 8 de maio de 2002) já foram proibidos como promotores do crescimento. Na União Européia, este movimento já se encontra mais adiantado, sendo que os quatro últimos microingredientes antimicrobianos ainda liberados (flavomicina, avilamicina, salinomicina e monensina sódica) deverão ser suprimidos progressivamente até 2006 (Brugalli, 2003). Estas proibições se devem à possibilidade do 
desenvolvimento de resistência bacteriana cruzada, que provocaria uma menor eficiência das substâncias à terapia (animal e humana) e à emergente exigência dos importadores por produtos livres de resíduos de antibióticos (Henrique, 1998; Soncini, 1999; Silva, 2000).

Por outro lado, tais medidas geram consequências econômicas importantíssimas. Em sete países da Comunidade Européia, o prejuízo causado pela proibição do uso de antimicrobianos como promotores do crescimento foi da ordem de US\$1,103 bilhões na cadeia da carne suína, sendo 58\% deste custo adicional absorvido pelos produtores (Butolo, 1999).

$\mathrm{Na}$ suinocultura, grande parte do prejuízo gerado pela retirada dos microingredientes antimicrobianos é resultante de quedas na produtividade na fase de creche. Esta fase corresponde ao período crítico pós-desmame, no qual animais submetidos a dietas contendo microingredientes antimicrobianos como promotores do crescimento apresentam aumentos médios de 16,4\% no ganho diário de peso e de 6,9\% na eficiência alimentar (Hays e Zimmerman, citados por Cromwell, 1991).

Os probióticos, prebióticos e os extratos vegetais vêm sendo testados nas dietas de suínos recém-desmamados como potenciais alternativas aos antibióticos e quimioterápicos, na tentativa de minimizar os prejuízos. Todavia, muitas questões sobre os efeitos desses promotores ainda necessitam ser esclarecidas. Assim, este trabalho teve como objetivo contribuir na elucidação dos efeitos da utilização de agentes antimicrobianos (bacitracina de zinco e olaquindox), probióticos (Bacillus subtilis e Bacillus licheniformis), prebióticos (mananoligossacarídeos) e extratos vegetais (alho, cravo, canela, pimenta e tomilho) sobre a morfometria dos órgãos, histologia do epitélio intestinal, microbiologia intestinal, frequência de diarréia, digestibilidade aparente de nutrientes, assim como, sobre o desempenho de suínos recém-desmamados. 


\section{REVISÃO DE LITERATURA}

\subsection{Morfofisiologia do aparelho digestório de leitões recém-desmamados}

A desmama no período de 14 a 28 dias de idade é um grande desafio aos leitões. Normalmente, há queda de desempenho nos dias posteriores a este evento devido à perda do contato com a porca, adaptação à dieta sólida, mudança de ambiente (bebedouros, cochos, temperatura e tensões sociais no grupo), maior desafio imunológico, etc (Mores et al., 1998).

Além do ambiente de creche ser, normalmente, mais desafiador em termos de contaminação, a proteção advinda do leite materno (imunoglobulinas) é retirada e o leitão ainda não possui a sua imunidade ativa desenvolvida, estando, portanto, muito susceptível a enfermidades (Mellor, 2000; Viola \& Vieira, 2003).

A retirada de uma dieta líquida (leite materno), altamente digestível e rica em gordura, lactose e caseína, e o início do consumo de uma ração seca, menos palatável, contendo amido, óleos e proteínas vegetais, traz consequências desafiadoras ao animal. Normalmente, por mais digestíveis, complexas e concentradas que sejam as dietas, os leitões recém-desmamados não conseguem suprir suas exigências, pois o seu consumo de ração, logo após a desmama, é muito baixo. Assim, é comum que haja sempre o comprometimento da saúde e da integridade de seu sistema digestório (Hedemann \& Jensen, 2001). Além de não suprir suas exigências, o leitão desmamado aos 21 dias de idade, ainda apresenta o sistema digestório imaturo (Smink, 2003). Há limitada capacidade física de ingestão (estômago e intestino delgado) e mesmo que o animal ingira quantidades satisfatórias de alimento, a secreção insuficiente de enzimas digestivas, ácido clorídrico, bicarbonato e muco não permite uma digestão e absorção de nutrientes adequada (Molly, 2001).

O estômago, primeiro sítio da digestão protéica, deve apresentar um $\mathrm{pH}$ de $2,0 \mathrm{a}$ 3,5. A acidez estomacal tem a função de estabelecer uma barreira bacteriana para proteger o intestino delgado contra a entrada de microrganismos patogênicos e proporcionar 
pH adequado para ação da pepsina. Entretanto, a desmama provoca uma queda drástica na quantidade de ácido láctico no estômago, devido à ausência de substrato (lactose) para os Lactobacillus. Este fato, aliado à insuficiente produção de ácido clorídrico pelas células parietais, leva a um quadro de pH elevado (Viola \& Vieira, 2003). Como consequência, segundo Lindeman (1986), a digestão incompleta e o quimo alimentar inadequadamente acidificado não ativam, de forma intensa, a secreção endócrina da parede do duodeno (secretina e colecistoquinina) que, por sua vez, prejudicará a secreção exócrina do pâncreas (tripsina, amilase, lípase, etc.), das glândulas de Brünner (bicarbonato de sódio), do fígado (sais biliares) e da própria parede do intestino delgado (maltase, sacarase, dipeptidases, aminopeptidases, etc.).

A ingestão insuficiente de alimentos, a digestão incompleta e, na maioria dos casos, a presença de farelo de soja (fatores alergênicos) nas dietas secas, levam a alterações na estrutura do epitélio intestinal. Tais modificações explicam grande parte da queda de desempenho dos leitões nos primeiros dias pós-desmame (Vente-Spreeuwenberg et al., 2004). Em apenas 24 horas após a desmama, há uma redução drástica na altura das vilosidades em todos os segmentos do intestino delgado, devido a uma maior descamação dos enterócitos. As vilosidades deixam de apresentar formas alongadas, semelhantes a dedos, e passam a se assemelhar com línguas ou folhas (Pluske et al., 1997; Hedemann et al., 2003; VenteSpreeuwenberg et al., 2004). Em resposta a este processo, acelera-se a diferenciação celular voltada a criptogênese, causando aprofundamento das criptas (Pluske et al., 1996; Hedemann et al., 2003; Vente-Spreeuwenberg et al., 2004).

O encurtamento das vilosidades e o aprofundamento das criptas acarretam perdas na atividade de algumas enzimas (isomaltase, sacarase e lactase) da borda em escova dos enterócitos (Miller et al., 1984). A rápida renovação celular nas criptas faz com que os enterócitos imaturos, insuficientemente diferenciados para a máxima expressão de atividade enzimática na borda em escova, cheguem ao ápice das vilosidades (Hampson \& Kidder, 1986). A redução da atividade enzimática da lactase, porém, pode ser mediada por mecanismos genéticos e ser mais dependente da idade do leitão do que da atrofia das vilosidades (Motohashi et al., 1997).

As peptidases da borda em escova também apresentam queda de atividade, principalmente na porção proximal do intestino delgado, onde a atrofia das vilosidades é mais pronunciada. Já na porção distal do intestino, na qual a redução da altura das vilosidades é menos intensa, a redução da atividade das peptidases pode ser causada apenas pela falta de alimento nas primeiras horas pós-desmame (Hedemann et al., 2003). 
As vilosidades desgastadas e as criptas aprofundadas apresentam um menor número de células absortivas e um maior número de células secretoras. Além da redução da absorção de carboidratos e aminoácidos, há uma queda na absorção de líquidos, sódio, potássio e cloreto, podendo levar o animal a uma diarréia osmótica (Nabuurs et al., 1993). A digestão incompleta de carboidratos e proteínas, somado ao $\mathrm{pH}$ mais elevado do estômago, também, pode propiciar um meio rico em substratos para bactérias dos intestinos delgado e grosso, provocando um desequilíbrio e favorecendo o crescimento de potenciais patógenos (Enterobacteriaceae, Escherichia coli e Clostridium). Tais microrganismos podem aderir à mucosa intestinal e, durante o processo de fermentação, produzir toxinas (cadaverina, putrescina, tiramina, histamina e outras aminas), agravando ainda mais os danos ao epitélio intestinal e podendo levar à morte (Molly, 2001).

Apesar de todos estes prejuízos, é o próprio alimento que irá fornecer os nutrientes necessários para que o organismo do animal se recupere. A simples presença do alimento irá estimular as funções digestivas intestinais (secreção de hormônios e enzimas e proliferação celular) até que se alcance a maturidade do sistema e o animal possa suprir suas exigências nutricionais (Kelly \& King, 2001).

A fisiologia do aparelho digestório de suínos desmamados de 14 a 28 dias de idade é, portanto, extremamente complexa, tornando a sua alimentação um enorme desafio.

\subsection{Microingredientes promotores do crescimento}

Diversos microingredientes são corriqueiramente utilizados em dietas para leitões recém-desmamados, com o intuito de controlar agentes prejudiciais ao processo digestivo, promovendo melhoras nos índices zootécnicos e maximizando a produção. Segundo o Compêndio Brasileiro de Alimentação Animal (1998), microingrediente é toda substância ou mistura de substâncias intencionalmente adicionadas aos alimentos para animais com a finalidade de conservar, intensificar ou modificar suas propriedades desejáveis e suprimir as propriedades indesejáveis e que seja utilizado sob determinadas normas. Os promotores do crescimento pertencem à classe dos pró-nutrientes (juntamente com antioxidantes, probióticos, prebióticos, etc.) definidos como microingredientes de alimentação, usados oralmente em pequenas quantidades, promovendo os valores intrínsecos de uma mistura de nutrientes em uma dieta animal. 
O conhecimento dos promotores de crescimento e suas funções, até hoje elucidadas ou sugeridas, devem ser o ponto de partida para estudos mais aprofundados objetivando ganhos no desempenho dos animais.

\subsection{Microingredientes antimicrobianos}

Dentre os microingredientes, os agentes antimicrobianos (antibióticos e quimioterápicos) são os promotores do crescimento e de eficiência alimentar de uso mais generalizado na produção animal, trazendo grandes benefícios, quando utilizados em doses subterapêuticas nas rações. Dewey et al. (1999), citados por Hayes et al. (2002), apresentaram um relatório, no qual estima-se que, nos Estados Unidos, os antimicrobianos para suínos são utilizados em $90 \%$ das dietas iniciais, em $75 \%$ das dietas de crescimento, em mais de $50 \%$ das dietas de terminação e $20 \%$ das deitas de reprodutores.

Os antibióticos são substâncias produzidas por fungos, leveduras ou bactérias que atuam contra bactérias, enquanto os quimioterápicos são substâncias obtidas por síntese química, com ação semelhante aos antibióticos (Menten, 2001). Representam um grupo de compostos com estruturas químicas heterogêneas e propriedades físico-químicas diferentes (Jong et al., 1985) que atuam sobre a microbiota intestinal de suínos.

\subsubsection{Modos de ação dos microingredientes antimicrobianos}

Pode haver dois tipos de ação direta dos antimicrobianos sobre as bactérias e/ou fungos sensíveis: a morte do agente ou a parada do seu crescimento e reprodução. No primeiro caso, denomina-se efeito bactericida, em relação às bactérias (ou fungicida, para os fungos). No segundo caso, existe um efeito bacteriostático (ou fungiostático). Em teoria, seria possível obter o efeito bactericida de qualquer antibiótico sobre um germe sensível, desde que se aumentasse a concentração do antimicrobiano. Esses efeitos podem se dar por interferência na síntese da parede celular (antibióticos $\beta$-lactanose e bacitracinas), alterações na permeabilidade da membrana citoplasmática (ionóforos), interferências na replicação cromossômica (quinoxalinas) e na síntese protéica (streptomicinas), segundo Tavares (1990) e Mellor (2000).

Apesar da ação direta sobre os microrganismos estar, de certa forma, esclarecida, o efeito dos antimicrobianos in vivo em suínos e outros animais domésticos não está totalmente compreendida. Desde o início da utilização dos antimicrobianos como promotores do 
crescimento, na década de 50 (Gustafson \& Bowen, 1997), foram realizados diversos estudos na tentativa de elucidar o mecanismo de ação. Apesar das várias hipóteses propostas até hoje, não há uma conclusão definitiva em consenso (Menten, 2001). O único aspecto de concordância geral é que os antimicrobianos agem sobre a microbiota como bactericidas ou bacteriostáticos causando efeitos interativos com a fisiologia do animal (Jong et al., 1985; Muramatsu et al., 1994).

Menten (1995) compilou diversos trabalhos que procuraram estabelecer o efeito dos antimicrobianos sobre a microbiota intestinal de suínos. Não se sabe ao certo se os microingredientes antimicrobianos causam redução na contagem total de microrganismos, mas os dados apresentados, nos trabalhos consultados, evidenciam que eles são capazes de induzir mudanças na proporção de populações bacterianas específicas, ou seja, promovem uma seleção de organismos adaptados ao ambiente modificado.

Essas alterações na microbiota seriam responsáveis por efeitos benéficos aos animais por meio de diversos mecanismos. Menten (1995), reunindo informações existentes na literatura, enumerou os mecanismos propostos até hoje: (a) efeito na economia de nutrientes; (b) efeito protetor contra a produção de toxinas no trato gastrintestinal; (c) efeito no controle de doenças subclínicas; e (d) efeito metabólico. Apesar de não haver conclusões definitivas sobre os meios de ação dos antimicrobianos promotores do crescimento, supõe-se que alguns destes mecanismos ajam simultaneamente para gerar os devidos ganhos de desempenho em suínos e outros animais domésticos (Menten, 1995).

\subsubsection{Efeito dos antimicrobianos na economia de nutrientes}

O efeito nutricional é caracterizado pela ação seletiva dos antimicrobianos, desfavorecendo o crescimento de bactérias que apenas competem pelo alimento com o hospedeiro, favorecendo bactérias que sintetizam vitaminas e aminoácidos essenciais para o suíno. Segundo Corpet (2000), a adição de diversos antimicrobianos provoca uma redução na produção de ácidos graxos voláteis, principalmente no ceco e no colo, indicando menor degradação de carboidratos pela microbiota. $\mathrm{O}$ mesmo autor ainda relata que algumas bactérias intestinais que inativam enzimas pancreáticas e metabolizam a proteína dietética, produzindo amônia e aminas biogênicas, são inibidas pelos antibacterianos, melhorando a digestibilidade protéica. 
Os agentes antimicrobianos também podem reduzir a irritação (queda da quantidade de microrganismos aderidos que produzem toxinas) e, consequentemente, a espessura e a massa do epitélio intestinal (Anderson et al., 1999), levando a crer que o animal necessitará de uma menor quantidade de nutrientes (aminoácidos e energia, principalmente) para a manutenção dos tecidos do trato gastrintestinal (Henry et al., 1987; Lima, 1999). O efeito redutor da produção de ácidos graxos, já citado, também contribui para não haver gastos extras na manutenção do epitélio intestinal, já que são estimuladores da proliferação celular, principalmente no intestino grosso (Lin \& Visek, 1991). A redução da população microbiana proporciona a redução da espessura da mucosa intestinal e também a queda na taxa de passagem do alimento pelo intestino (Hardy, 2002). Isto ocorre devido ao menor estímulo dos ácidos produzidos pelas bactérias sobre a musculatura da parede intestinal (Yokokura et al., 1977). Assim, haverá mais tempo para a digestão, aumentando a disponibilidade de nutrientes para absorção (Hardy, 2002). Com a melhora da digestibilidade há, inclusive, redução na quantidade de resíduos produzidos e na excreção de nitrogênio e fósforo nas fezes (Roth \& Kirchgessner, 1993).

\subsubsection{Efeito protetor dos antimicrobianos contra a produção de toxinas}

A quantidade de amônia no intestino, tóxica aos enterócitos, está positivamente correlacionada com a microbiota. A amônia é formada pela ação da urease (de origem microbiana ou vegetal) sobre a uréia, ou pela deaminação de aminoácidos pela microbiota (Visek, 1978). Os antimicrobianos na dieta reduzem a produção de amônia e de outros metabólitos tóxicos (aminas e endotoxinas) pela microbiota (Jin et al., 1997), protegendo o epitélio intestinal (Butolo, 1999). A toxicidade dessas substâncias aumenta o turnover celular no

epitélio intestinal e causa maior gasto de energia e proteínas para o animal. Portanto, aceita-se que o mecanismo de proteção do epitélio contra substâncias tóxicas pode aumentar o desempenho de animais alimentados com agentes antimicrobianos, devido à menor demanda energética do trato gastrintestinal (Menten, 1988, 1995).

\subsubsection{Efeito dos antimicrobianos no controle de doenças subclínicas}

O controle de doenças subclínicas é o mecanismo mais aceito, sendo também o de maior dificuldade para comprovação. Não há um efeito identificado sobre um determinado 
microrganismo causador de uma determinada doença. Os promotores do crescimento antimicrobianos simplesmente agem sobre bactérias no trato gastrintestinal que provocam doenças não diagnosticáveis, mas que, de alguma maneira, deprimem o crescimento do animal (Menten, 1995).

A estimulação crônica do sistema imunológico, respondendo às doenças subclínicas, pode promover redução no consumo de ração e demanda nutrientes que poderiam ser direcionados para a síntese de proteína (Williams et al., 1997a). O controle das doenças subclínicas pelos promotores de crescimento antimicrobianos permite que os animais expressem, de maneira mais intensa, o seu potencial genético para o crescimento e deposição de carne, produzindo carcaças mais magras (Williams et al., 1997a).

\subsubsection{Efeito metabólico dos antimicrobianos}

O efeito metabólico implica no efeito direto dos antimicrobianos sobre o metabolismo do animal. Esse modo de ação não é apropriado para aqueles agentes antimicrobianos que não são absorvidos e que permanecem na luz intestinal, a não ser que a que a ação ocorra diretamente sobre as células do epitélio intestinal, afetando a absorção de nutrientes (Bellaver, 2000). Menten (1995) reuniu trabalhos científicos que demonstram a ação metabólica de antimicrobianos injetados em animais via intravenosa. Alguns dos efeitos encontrados: aumentos nas atividades de enzimas regulatórias citosólicas, na ativação de aminoácidos e na incorporação dos mesmos a proteínas do fígado. No entanto, lembra que a maior parte dos efeitos metabólicos encontrados podem ser uma consequência secundária da melhora na eficiência alimentar e no desempenho de animais alimentados com antibacterianos promotores do crescimento.

\subsection{Probióticos}

Probióticos, segundo o Compêndio Brasileiro de Alimentação Animal (1998), são cepas específicas de várias espécies de microrganismos que agem como auxiliares na recomposição da microbiota intestinal dos animais, diminuindo a concorrência dos microrganismos patogênicos ou indesejáveis. Anteriormente, Fuller (1989) havia definido probiótico como sendo um microingrediente à base de microrganismos vivos que afetam beneficamente o animal hospedeiro, melhorando o balanço microbiano intestinal. 
Certamente, existem dezenas de definições para os probióticos, todas muito semelhantes. Complementando essas definições, Collins \& Gibson (1999) sugeriram que um probiótico eficaz deve:

a) exercer efeito benéfico;

b) não ser patogênico e/ou tóxico;

c) conter um grande número de células viáveis;

d) ser capaz de sobreviver ao metabolismo digestivo intestinal;

e) manter-se viável durante a estocagem e uso nas dietas;

f) ter boa palatabilidade ou não interferir nas propriedades sensoriais; e

g) ser isolado ou detectado em seu hospedeiro.

Há vários tipos de probióticos no mercado, sendo que a maior parte é composta por espécies de bactérias dos gêneros Lactobacillus, Bacillus, Streptococcus e até de levedura Saccharomyces cerevisiae. Os probióticos podem conter apenas uma espécie de microrganismo ou mais (Turner et al., 2001).

Os probióticos produzem resultados de desempenho muito inconsistentes, tanto em suínos quanto em aves (NRC, 1998). A espécie de microrganismo utilizada no probiótico, o histórico de doenças, o "status" sanitário e a temperatura das instalações podem interferir muito na ação dos promotores do crescimento, inclusive dos probióticos (Williams et al., 1997b, NRC 1998). Além disso, o probiótico pode não fazer parte da microbiota natural do hospedeiro, ou ainda, não ser inoculado em quantidades suficientes (Collins \& Gibson, 1999).

A utilização de antimicrobianos e outros microingredientes associados aos probióticos, a composição e o processamento das dietas e o manejo de alimentação também podem explicar parte da inconsistência dos resultados (Cheeson, 1994). Muitos microrganismos probióticos não resistem a determinados antibióticos ou à peletização (Turner et al., 2001).

\subsubsection{Modos de ação dos probióticos}

Kelly \& King (2001) relatam que os leitões nascem livres de contaminação microbiológica, mas, em questão de horas, já há colonização por Lactobacillus, Bifidobacteria e Bacteróides, correspondendo a 90\% da microbiota normal de um suíno em aleitamento. Outros $5 \%$ da microbiota são representados por microrganismos anaeróbios facultativos (E. coli e Enterococci) e menos de $1 \%$ por microrganismos como Clostridium e Staphylococcus 
(Huyghebaert, 2003). Após a desmama há uma grande queda na população de bactérias lácticas e um aumento na população de Escherichia coli e outros microrganismos patógenos oportunistas. Estas bactérias patogênicas, principalmente a E. coli, podem se aderir ao epitélio intestinal por meio de fímbrias, se multiplicarem e desequilibrar a microbiota, causando as diarréias pós-desmama e até a morte.

Os microrganismos probióticos adicionados à dieta (ração ou água) podem proteger o intestino dos animais contra microrganismos patógenos e trazer benefícios por diferentes mecanismos propostos: exclusão competitiva (Holzpafel et al., 1998; Ouwehand et al., 1999; Menten, 2001), antagonismo direto (Chateau et al., 1993; Bomba et al., 1996; Leedle, 2000a; Menten 2001), estímulo ao sistema imune (Jin et al., 1997; Andreatti Filho \& Sampaio, 1999; Leedle, 2000b), efeito nutricional (Jin et al., 1997; Leedle, 2000b), e supressão da produção de amônia e neutralização de enterotoxinas (Jin et al., 1997).

\subsubsection{Efeito de exclusão competitiva dos probióticos}

Os microrganismos probióticos de exclusão competitiva, quando adicionados à dieta e são viáveis, logo passam a prevalecer na microbiota, aderindo-se ao epitélio intestinal. Assim, a adesão de microrganismos patógenos é dificultada (Roth, 2000). Ao mesmo tempo, os microrganismos probióticos aderidos à parede do epitélio intestinal também possuem uma maior facilidade de capturar e metabolizar nutrientes presentes no lúmen do que os microrganismos patógenos que não estão aderidos (Roth, 2000). Entretanto, a competição pelos nutrientes, como mecanismo da exclusão competitiva, ainda não foi claramente demonstrada (Menten, 2001).

Segundo Huyghebaert, 2003, a exclusão competitiva se aplica a probióticos à base de microrganismos dos gêneros Lactobacillus, Enterococcus e Streptococcus, pois são bactérias que, como os principais patógenos, colonizam o trato gastrintestinal, aderindo-se por meio de fímbrias ao epitélio intestinal. Já os Bacillus spp. e a levedura (Saccharomyces cerevisiae) são microrganismos não colonizadores, que apenas transitam pelo intestino juntamente com o conteúdo intestinal e não se aderem ao epitélio.

Existem produtos probióticos exclusivamente voltados para o mecanismo de exclusão competitiva, mas que, no entanto, podem também exercer os outros efeitos relacionados aos probióticos (Menten, 2001). São produtos aplicados, normalmente, na água de animais recém-nascidos e que têm, como objetivo, a colonização do trato gastrintestinal e a estabilização da microbiota pelo probiótico, evitando a instalação de patógenos como a 
Salmonella (Hooge, 1999). Menten (2001) lembra que nos Estados Unidos, segundo o Food and Drog Aminitration (FDA), os probióticos são chamados "direct feed microbial" (DFM) e classificados como alimentos, enquanto que os produtos de exclusão competitiva são listados como drogas, por possuírem propriedades terapêuticas.

\subsubsection{Efeito de antagonismo direto dos probióticos}

O efeito de antagonismo direto se dá pela produção de ácidos orgânicos, ou substâncias antibióticas (bacteriocinas, nisina, acidofilina, peróxido de hidrogênio, etc.) pelos probióticos (Vanbelle et al., 1990). As bactérias lácteas, por exemplo, reduzem o pH intestinal pela produção de ácido orgânicos (principalmente ácido lático). Patógenos como E. coli e Salmonella spp. se desenvolvem em pH mais elevado, havendo inibição do crescimento dessas populações. Além disso, as bactérias lácteas também produzem peróxido de hidrogênio, uma substância efetiva contra vírus e outras espécies de bactérias (Roth, 2000).

As bacteriocinas são substâncias protéicas bactericidas produzidas por bactérias, inclusive as probióticas, que matam ou inibem o crescimento de bactérias específicas (Leedle, 2000b; Silva, 2000). Segundo Silva (2000), as bacteriocinas possuem um estreito espectro de atividade inibitória, ligam-se a receptores celulares específicos e não são letais para as células que as produzem. Elas diferem dos antibióticos, pois estes são produzidos por fungos e bactérias e as bacteriocinas, exclusivamente por bactérias (Leedle, 2000b). Apesar da capacidade bactericida de muitas bacteriocinas ser comprovada in vitro, não existem trabalhos que demonstrem, de forma efetiva e consistente, esta ação in vivo (Berg, 1998).

Os probióticos, geralmente anaeróbios, também atuam como removedores de oxigênio, indisponibilizando o ambiente para bactérias patogênicas e favorecendo o crescimento de bactérias anaeróbias desejáveis (Vassalo, 1995).

\subsubsection{Efeito dos probióticos sobre o sistema imunológico}

Alguns trabalhos têm indicado que o estímulo específico e não específico do sistema imune pode ser um outro mecanismo pelo qual os probióticos podem beneficiar o animal hospedeiro (Pouwels et al., 1996; Fukushima et al., 1998). O mecanismo, no entanto, não está esclarecido, uma vez que ao que tudo indica, componentes específicos da parede celular de 
alguns probióticos podem atuar com adjuvantes, melhorando a resposta do sistema imune humoral (Kaila et al., 1992).

Menten (2001) revisou o assunto e verificou que as respostas de aumento na produção de anticorpos, na ativação de macrófagos, proliferação de células $\mathrm{T}$ e produção de interferon estão relacionadas à utilização de probióticos à base de Lactobacillus e Bifidobacterium. Os Bacillus, também, podem aumentar a produção de anticorpos em trutas (Raida et al., 2003), aumentar a ativação de macrófagos e células $\mathrm{T}$ e induzir o aumento dos níveis séricos de alfa-interferon (Hooge, 2003).

Roth (2000) defende a tese de que os probióticos, na verdade, podem não estimular, mas apenas propiciar ao sistema imunológico as condições das quais necessita para atuar normalmente. Portanto, o estímulo da atividade imunológica dos animais alimentados com probióticos ainda é uma questão muito pouco estudada, não havendo nenhum tipo de constatação conclusiva na literatura.

\subsubsection{Efeito nutricional dos probióticos}

A prevalência dos microrganismos probióticos no intestino dificulta a fixação dos patógenos, por exclusão competitiva e/ou antagonismo direto. Assim, haverá menor produção de amônia, toxinas e aminas pelos patógenos, contribuindo para a integridade do epitélio intestinal (Guillot, 2000). Sugere-se, então (Stewart \& Chesson, 1993; Roth, 2000), que os probióticos afetam a permeabilidade do epitélio intestinal, proporcionando maior eficiência na digestão (secreção de enzimas) e absorção de nutrientes (enterócitos íntegros). Além de proteger o epitélio intestinal, os probióticos evitam que os patógenos utilizem aminoácidos, minerais e carboidratos para fermentação e produção de toxinas (Guillot, 2000). Dessa maneira, espera-se que o animal hospedeiro melhore a eficiência alimentar e o desempenho.

Os probióticos, também, produzem enzimas, vitaminas e desconjugam sais biliares, facilitando a digestão (Gilliand, 1988). Assim, podem transformar compostos razoavelmente solúveis e não digeríveis em compostos altamente solúveis (Jorgensen, 1989). O Bacillus subtilis e o Bacillus licheniformis possuem atividade secretora de enzimas proteolíticas, aminolíticas e lipolíticas, auxiliando o hospedeiro a digerir certos tipos de substratos (Jensen \& Jensen, 1992).

Há uma terceira possibilidade dos probióticos atuarem na melhora da nutrição. As bactérias produtoras de ácido lático reduzem o pH do conteúdo intestinal (Roth, 2000). Esta 
acidificação pode facilitar e aumentar o transporte de ácidos graxos voláteis através do epitélio intestinal, pois em pH abaixo de 6,0 os ácidos se apresentam na forma dissociada, dez vezes mais absorvida que na forma não dissociada (Leedle, 2000b). Uma vez absorvidos, parte destes ácidos graxos pode se transformar em energia para os enterócitos, melhorando o metabolismo celular e, consequentemente, a absorção de nutrientes.

\subsubsection{Supressão da produção de amônia e neutralização de enterotoxinas pelos probióticos}

Os probióticos podem reduzir a habilidade dos patógenos para a produção de toxinas, amônia e aminas devido aos mecanismos de exclusão competitiva e/ou antagonismo direto (Guillot, 2000). Há, também, um efeito mais direto, que consiste na produção, pelos probióticos, de substâncias que neutralizam as toxinas (Reddy, 1988).

Em crianças, probióticos à base de Clostridium butyricu, Streptococcus faecalis

e Bacillus mesentericus diminuíram os níveis séricos de endotoxinas (Urao et al., 1999). Suspeita-se que houve decréscimo no número microrganismos potencialmente patogênicos na microbiota e/ou queda na taxa de translocação de endotoxinas através da mucosa intestinal.

Estes mecanismos devem, portanto, ser melhor estudados a fim de se adequar o uso dos probióticos na produção animal.

\subsection{Prebióticos (mananoligossacarídeos)}

Prebióticos são definidos como compostos não digeríveis por enzimas, sais e ácidos produzidos pelo organismo animal, mas seletivamente fermentados pelos microrganismos do trato gastrintestinal (Gibson \& Roberfroid, 1995). Os prebióticos são representados, principalmente, pelos frutoligossacarídeos, glucoligossacarídeos e mananoligossacarídeos.

Os mananoligossacarídeos são oligossacarídeos presentes na parede celular de leveduras (Saccharomyces cerevisae) que não são digeridos ou fermentados pelos microrganismos gastrintestinais. A estrutura dos mananoligossacarídeos é composta por uma cadeia complexa de manose fosforilada, glucose e proteína, conferindo certa resistência à degradação pelas enzimas digestivas e bactérias do trato gastrintestinal (Spring, 2000).

A parede celular de levedura é constituída, principalmente, por proteína e carboidrato. Este último, por sua vez, contém os dois principais açúcares (glucose e manose) em 
proporções semelhantes, além de $\mathrm{N}$-acetilglucosamina (Spring, 2000). Após a fermentação, a célula de levedura é quebrada, separando o material intracelular do extracelular. Em seguida, o material extracelular (parede celular da levedura) sofre um tratamento enzimático para a obtenção do mananoligossacarídeo purificado, produto final utilizado como microingrediente na ração (Spring, 2000).

O uso de mananoligossacarídeos na dieta de leitões recém-desmamados traz, em média, um aumento de 4,4\% no ganho diário de peso (Pettigrew, 2000), sendo que, utilizando-se antimicrobianos consegue-se um acréscimo médio de 16\% no ganho diário de peso (NRC, 1998). Apesar de haver um efeito inferior aos antimicrobianos, o efeito positivo sobre o desempenho de leitões recém-desmamados parece ser efetivo (Pettigrew, 2000).

\subsubsection{Modos de ação dos mananoligossacarídeos}

\subsubsection{Ação direta dos mananoligossacarídeos sobre a microflora}

Os mananoligossacarídeos atuam como ligantes de alta afinidade, proporcionando um meio de aglutinação competitivo para determinados tipos de bactérias.

Muitas bactérias, em especial as gram negativas, necessitam utilizar fímbrias de manose específica tipo 1 para aderirem à mucosa intestinal e colonizá-la. Assim, o mananoligossacarídeo ocupa o sítio de ligação da lectina nas fímbrias dessas bactérias, sendo capazes de bloquear a aderência de patógenos na superfície do epitélio intestinal e evitar a colonização (Mathew et al., 1993; Collet, 2000; Macari \& Maiorka, 2000). Testes de aglutinação, utilizando o mananoligossacarídeo, mostraram que o mesmo foi efetivo em ligar-se às cepas de E. coli e Salmonella spp. (White et al., 2001), de E. coli R15, S. typhimurium 29E, S. enteriditis 13A e S. enteriditis 371 (Newman et al., 1995). No entanto, existe um certo grau de especificidade na ligação das fímbrias ao mananoligossacarídeo. Finucane et al. (1999), citados por Dawson \& Pirvulescu (1999), verificaram que somente 51\% das cepas de E. coli e 53\% das cepas de Salmonella spp. testadas manifestaram expressão de fímbrias específicas para manose. Também, foi encontrada variação entre as espécies, sendo que as percentagens de cepas de Salmonella typhimirium e S. enteritidis, que apresentaram adesão a receptores de manose, foram de 80 e $67 \%$, respectivamente. Essas diferenças ocorrem devido aos tipos de ligações e grau de fosforilação presentes na estrutura manana, que variam de acordo com as cepas de levedura (Devegowda, 1997). 
A capacidade do mananoligossacarídeo interferir na adesão de bactérias patogênicas ao epitélio intestinal sugere, também, que possa haver inibição da aglutinação entre bactérias, indispensável para a transferência de plasmídeos através de conjugação (Maisonneuve et al., 2001). Dessa maneira, além de carrear microrganismos através do trato gastrintestinal, impedindo a colonização, o mananoligossacarídeo ainda pode, provavelmente, bloquear um dos mecanismos microbiológicos geradores de variabilidade genética, ou seja, pode impedir a formação de cepas de bactérias fecais gram negativas resistentes (Maisonneuve et al., 2001).

\subsubsection{Efeito indireto dos mananoligossacarídeos sobre a microflora}

Estudos sugerem que o mananoligossacarídeo possa exercer efeito indireto sobre o controle de patógenos, pois, apesar dos clostrídios não se aderirem através de fímbrias, a quantidade desse patógeno foi reduzida em resposta às mananas incluídas na dieta (Finucane et al., citados por Dawson \& Pirvulescu, 1999). Uma possível explicação para esse resultado seria a relação existente entre o mananoligossacarídeo e as outras bactérias. Alterações na multiplicação de organismos anaeróbicos benéficos poderiam inibir de forma competitiva o crescimento e a atividade de clostrídios (Dawson \& Pirvulescu, 1999). Além disso, Ferket (2003) sugere que os mananoligossacarídeos podem reforçar a barreira mucosa do epitélio inestinal e/ou estímular a imunidade, o que poderia explicar, em parte, a redução dos clostrídios.

\subsubsection{Efeito dos mananoligossacarídeos sobre a morfohistologia intestinal e digestibilidade dos nutrientes}

Impossibilitando a colonização de bactérias patogênicas, o mananoligossacarídeo favorece o crescimento de bactérias benéficas lácticas e, conseqüentemente, pode haver queda do $\mathrm{pH}$ do bolo intestinal (Ferket, 2002). A redução do pH impede a proliferação de bactérias de putrefação que liberam amônia como subproduto da fermentação, prejudicial para a integridade do epitélio intestinal (Ferket, 2003). Sendo assim, pode haver uma contribuição para melhora da integridade do epitélio intestinal.

Em perus suplementados com mananoligossacarídeo, Savage et al. (1997) e Ferket (2002) observaram diminuição nas profundidades de cripta, maior concentração de células caliciformes (produtoras de muco) nos vilos e menor espessura da camada muscular do 
epitélio do intestino delgado. $\mathrm{O}$ aumento da produção de muco leva a uma maior proteção contra microrganismos patogênicos, pois constitui a principal barreira contra infecções entéricas.

Além do provável efeito na integridade do epitélio intestinal de perus, Ferket (2002) encontrou uma redução no teor de ácidos graxos voláteis do jejuno em cerca de $40 \%$, sendo o ácido propiônico o mais reduzido. Houve assim, uma maior disponibilidade de amido e açúcares, principais substratos da fermentação microbiana, o que levou a um acréscimo de $3 \%$ no valor de energia metabolizável aparente da dieta.

\subsubsection{Efeito dos mananoligossacarídeos sobre a imunologia}

As estruturas moleculares das bactérias invasoras, como lipopolissacarídeos e peptidioglicanos e, possivelmente, as estruturas de manose das paredes celulares de leveduras são reconhecidas pelo sistema imunológico. O sistema imunológico do hospedeiro responde através da secreção hepática das proteínas aglutinantes da manose que, por sua vez, une-se às bactérias e ativa a cascata de complemento do sistema imunológico do hospedeiro (Newman, 1994). Este mecanismo contribui para a ativação do sistema humoral e títulos de imunoglobulinas, aumentando a $\operatorname{IgA}$ na bile e $\operatorname{IgG}$ plasmática, fato já verificado em pintos (Savage et al., 1996). Com o aumento de secreção de IgA pela mucosa intestinal, os agentes patogênicos passam a ser mais vulneráveis à fagocitose (Ferket, 2003).

A liberação de citocinas, por parte de microrganismos patogênicos, provoca inflamação e resposta imunológica inata que, por consequência, levam à febre (com queda no apetite), impedem a concentração de reservas corporais no fígado, músculos e ossos, suprimem a absorção de nutrientes nos intestinos e aumentam as perdas de fluídos corporais, na forma de diurese ou diarréia (Ferket, 2003). Apesar de estimular a resposta humoral, o mananoligossacarídeo pode reduzir a resposta inflamatória ativa, melhorando o desempenho de animais expostos ao estresse imunológico crônico (Ferket, 2002).

\subsection{Extratos Vegetais}

A utilização de extratos vegetais e plantas medicinais para humanos data de milhares de anos, sendo muito difundida no Egito Antigo, China, Índia e Grécia (Martins et al., 2000). Muitos extratos vegetais naturais têm fornecido a base para modernos medicamentos, tais como a digoxina da planta digitalis e a efedrina da planta chinesa "na huang" (Brugalli, 2003). 
Recentemente, espécies como Hypericum perforatum (hipérico), Allium sativum (alho), Origanun majorana (manjerona), Origanum vulgare (orégano), Menta piperita (hortelã), Rosmarinus officinalis (alecrim), Thymus vulgaris (tomilho), Juniperus communis (zimbro) Capsicum annuum (pimenta vermelha) e Allium cepa (cebola) despertaram interesse de pesquisadores da área animal, pois possuem princípios ativos que poderiam trazer benefícios aos animais (Kamel, 2000).

Os princípios ativos dos vegetais são moléculas de baixo peso molecular oriundas do metabolismo secundário dos vegetais. São glucosídeos, alcalóides (álcoois, aldeídos, cetonas, éters, ésteres, lactonas), compostos fenólicos e polifenólicos (quinonas, flavonas taninos e cumarinas), terpenóides (mono e sesquiterpenos e esteróides), saponinas, mucilagens, flavonóides, etc (Huyghebaert, 2003). Estão presentes em todas as partes ou em partes específicas das plantas (Martins et al., 2000).

Atualmente, os produtos à base de extratos vegetais podem ser compostos por uma mistura de princípios ativos isolados e/ou de óleos essenciais. Os óleos essenciais são uma mistura complexa de componentes ativos obtidos por processo de vaporização. A concentração dos princípios ativos nos óleos essenciais pode variar de acordo com a parte da planta utilizada (caule, folhas, semente, etc.), espécie de planta (por exemplo, extrato de tomilho contém $41 \%$ de timol e de orégano, 10\%) e condições ambientais de cultivo da planta (Kamel, 2000).

Pesquisas recentes têm demonstrado a existência de um efeito sinérgico entre os princípios ativos primários e secundários das plantas. Os componentes secundários, princípios ativos encontrados em pequenas concentrações, atuariam como potencializadores dos compostos primários (Kamel, 2000). Para o Origanun vulgare (orégano), foram descritos mais de 30 compostos químicos antibacterianos, sendo que apenas três ou quatro atuam isoladamente na concentração encontrada neste vegetal (Kamel, 2000). Portanto, os produtos a base de extratos vegetais devem conter diferentes princípios ativos (misturas) de diferentes plantas para acentuar os efeitos (Langhout, 2000).

Um mesmo princípio ativo pode ser encontrado em diversas plantas em concentrações diferentes. Determinadas espécies de plantas possuem princípios ativos em altas concentrações. São exemplos (Kamel, 2000): cinamaldeído (90\% no extrato da canela), eugenol ( $80 \%$ no extrato do cravo) e timol ( $41 \%$ no extrato tomilho).

As atividades antihelmíntica, antibiótica e antioxidante de alguns compostos ativos já foram demonstradas in vitro por diversos trabalhos (Oliveira, 1991; Pozo, 1997; Doria, 1999; Guarrera, 1999; Essawi \& Srour, 2000; Kamel, 2000; Hernández et al., 2004). Já os 
trabalhos in vivo são escassos e não apresentam dados conclusivos, mas sugerem que os extratos vegetais poderiam apresentar os mesmos efeitos comprovados in vitro, além de atividade antiinflamatória, estimuladora da circulação periférica, do consumo e da produção de sucos gástricos e bílis (Gupta \& Sandhu, 1997 e 1998; Ader et al., 2000).

Segundo Kohlert et al. (2000), os princípios ativos dos extratos vegetais são absorvidos no intestino pelos enterócitos e metabolizados rapidamente no organismo animal. Os produtos deste metabolismo são transformados em compostos polares, através da conjugação com o glicoronato, e excretados na urina. Outros princípios ainda podem ser eliminados pela respiração como $\mathrm{CO}_{2}$. A rápida metabolização e a curta meia vida dos compostos ativos levam a crer que existe um risco mínimo de acúmulo nos tecidos (Kohlert et al., 2000).

Os raros trabalhos que utilizaram os extratos vegetais na dieta de suínos mostram alguns resultados positivos no desempenho dos animais, muito embora conflitantes (Grela et al., 1998; Radford et al., 2002; Rodas et al., 2002). Além disso, os dados mostram que, dependendo do extrato vegetal utilizado e da quantidade, pode haver queda no desempenho (Horton et al., 1991). Entretanto, os resultados encontrados in vitro justificam uma maior investigação sobre os mecanismos de ação in vivo, a fim de se adequarem os níveis de inclusão e a escolha dos extratos para cada situação de desafio (Turner et al., 2001; Hernández et al., 2004).

\subsubsection{Modos de ação dos extratos vegetais}

Muito embora alguns efeitos já tenham sido demonstrados, há ainda um grande desconhecimento dos mecanismos envolvidos nos processos. Langhout (2000) afirma que os extratos vegetais podem aumentar o desempenho dos animais, mas os efeitos devem ser menos pronunciados se comparados aos antimicrobianos. Além disso, muitas pesquisas ainda devem ser realizados associando os princípios ativos e seus efeitos in vivo, a fim de se alcançar ganhos

expressivos no desempenho de suínos suplementados com microingredientes promotores do crescimento à base de extratos vegetais.

\subsubsection{Efeito antimicrobiano dos extratos vegetais}

A atividade antimicrobiana é uma da mais evidentes dos extratos vegetais. Existem diversos trabalhos na literatura demonstrando tal atividade in vitro (Mahmoud, 1994; Madsen \& Bertelsen, 1995; Cichewicz \& Thorpe, 1996; Martinez, et al., 1996; Pozo, 1997; 
Ahmad et al., 1998; Gupta \& Sandhu, 1998; Mahrour et al., 1998; Guarrera, 1999; Mahasneh \& El-Oqlah, 1999; Navarro \& Delgado, 1999; Dorman \& Deans, 2000; Essawi \& Srour, 2000; Nascimento et al., 2000; Araújo \& Leon, 2001; Harris et al., 2001; Karanika et al., 2001; Salvat et al., 2001; Srinivasan, et al., 2001; Vieira et al., 2001; Huyghebaert, 2003). Estudos da atividade mínima inibitória (medida padrão de poder bacteriostático) de extratos vegetais em alguns microrganismos demonstraram que alguns extratos são tão eficientes quanto alguns antimicrobianos (Tabak et al., 1991; Kamel, 2000). O óleo essencial de uma única planta pode ter amplo espectro de ação bactericida in vitro. Por exemplo, o óleo essencial de canela, que contém cinamaldeído, eugenol e carvacrol (Tabak et al., 1991), apresenta atividade inibitória contra Escherichia coli, Pseudomonnas aeruginosa, Enterococcus faecalis, Staphylococcus epidermis, Staphylococcus aureus, Klebsiella pneumoniae, Salmonella typhimurium, Campylobacter e Clostridium perfringes (Chang et al., 2001).

Cada espécie de planta apresenta uma intensidade diferenciada de atividade antibacteriana. De acordo com Huyghebaert (2003), a atividade antimicrobiana é fraca para o gengibre e pimenta, média para orégano, alecrim, tomilho, cominho, coentro e sálvia, e forte para cravo, mostarda, canela e alho.

Os modos como os princípios ativos dos extratos vegetais agem sobre as células bacterianas são muito semelhantes aos dos antimicrobianos. O compostos fenólicos carvacrol e o timol são os principais componentes dos extratos de orégano e tomilho, respectivamente. A extremidade hidrofóbica destes componentes interage com a membrana celular das bactérias, alterando sua permeabilidade para cátions como hidrogênio $\left(\mathrm{H}^{+}\right)$e potássio $\left(\mathrm{K}^{+}\right)$. O descontrole no gradiente de íons leva as células bacterianas à morte (Lambert et al., 2001; Smink, 2003). Já a alicina (princípio ativo do alho) age sobre bactérias, leveduras e fungos, da mesma maneira que o tiossulfonato, retirando o grupamento $\mathrm{SH}$ - das enzimas bacterianas e inativando-as (Amagase et al., 2001).

Apesar das demonstrações de que os extratos vegetais podem apresentar atividade antimicrobiana in vivo, os mecanismos pelos quais este processo ocorre ainda são muito obscuros (Dorman \& Deans, 2000). 


\subsubsection{Efeito antioxidante dos extratos vegetais}

Há alguns anos, foi demonstrado que os flavonóides e os ácidos fenólicos (encontrados em diversas plantas) protegem alimentos, células e tecidos contra o efeito deletério da reação de oxidação. Extratos de canela, por exemplo, podem ter ação igual, ou melhor que o BHT (butil hidroxitolueno). O alecrim (Rosmarinus officinalis L.) e a sálvia (Salvia officinalis L.) são considerados as ervas mais potentes como antioxidantes (Madsen \& Bertelsen, 1995). Em alimentos para humanos, os principais componentes antioxidantes (carnosol, ácido carnosóico, rosmaridifenol, rosmariquinona) podem interferir negativamente no sabor ou aroma. Por isso, não se usam os óleos essenciais de cravo, canela, orégano, apesar de também apresentarem ação antioxidante (Madsen \& Bertelsen, 1995).

A ação direta de extratos vegetais como antioxidantes em alimentos, inclusive em carnes e banha suína, tem sido amplamente pesquisada e comprovada (Madsen \& Bertelsen, 1995). Entretanto, a aplicação desta propriedade in vivo para animais é muito pouco pesquisada.

Apenas um único trabalho encontrado na literatura (Lopez-Bote et al., 1998), demonstra que óleoresinas de sálvia e alecrim (extração por solventes orgânicos), adicionados à dieta de pintos, aumentaram a estabilidade oxidativa dos cortes de coxa e peito. $\mathrm{O}$ efeito foi mensurado pela quantidade de ácido tiobarbitúrico (TBARS) nos cortes. Os autores também comentam que a adição dos óleos ao alimento dos animais, altera a composição dos ácidos graxos no organismo e aumenta a porcentagem de ácidos graxos polinsaturados (PUFA), predispondo os tecidos do animal à oxidação. No entanto, os polifenóis e fenóis presentes em altas quantidades nestes óleos contribuem para aumentar a estabilidade oxidativa, compensando o aumento na dos polinsaturados. Como conclusão, pôde-se afirmar que parte dos antioxidantes, presentes nos óleos ingeridos, foi retida nos músculos e continuaram ativos após o abate dos animais.

Desta maneira, pode-se supor que os extratos vegetais, quando fornecidos diretamente na dieta, podem expressar a atividade antioxidante nos tecidos vivos, protegendo os animais de agentes oxidantes. Entretanto, tal fato ainda não foi estudado. Assim, o efeito antioxidante dos extratos vegetais merece ser profundamente estudado, pois pode trazer benefícios para o desempenho animal e para a indústria processadora de carnes. 


\subsubsection{Efeito dos extratos vegetais sobre a digestibilidade}

Alguns trabalhos afirmam que o uso de extratos vegetais na dieta pode aumentar a digestibilidade de nutrientes (Platel \& Srinivasan, 1996; Wang \& Bourne, 1998; Hernández et al., 2004). O aumento da atividade enzimática, a alteração na morfometria dos órgãos e o combate a microrganismos patogênicos são algumas das hipóteses propostas para justificar este efeito.

Desde a década de 80 e início da de 90, alguns trabalhos (Ganesh-Baht et al., 1984; Sambaiah \& Srinivasan, 1991) já investigavam, em ratos, o aumento na secreção e a mudança na composição da bile, provocados por óleos essenciais de pimenta e cominho. Mais recentemente demonstrou-se, também em ratos, que a capsaicina (princípio ativo da pimenta) também era capaz de estimular a salivação (produção de amilase) e aumentar a secreção das enzimas pancreáticas, da sacarase e da maltase (Platel \& Srinivasan, 1996; Wang \& Bourne, 1998). Além da capsaicina, o cinamaldeído (princípio ativo da canela) também teria ação estimulante sobre as enzimas pancreáticas (Wang \& Bourne, 1998).

Em humanos, sabe-se que os componentes pungentes das ervas aromáticas (pimenta, cravo, canela, etc.) aumentam a secreção de saliva e suco gástrico devido ao estímulo do sistema nervoso central, proporcionado pelo cheiro e sabor (Sreenivasamurthy \& Krishnamurthy, 1959).

A modulação da microbiota pelos extratos vegetais, também, pode contribuir no processo digestivo. Piva et al. (2002ab) demonstraram que o carvacrol pode reduzir a população de Enterobacteriaceae spp., reduzindo também a produção de amônia, tóxica às células do epitélio intestinal. Assim, poderia haver uma ação protetora do epitélio intestinal, melhorando a absorção de nutrientes.

Portanto, o efeito estimulante na produção de enzimas e secreções intestinais é o mecanismo mais estudado na tentativa de explicar a melhora da digestibilidade. No entanto, outros mecanismos podem estar atuando. A morfometria dos órgãos parece não ser alterada pelos extratos vegetais (Hernández et al., 2004), mas a modulação da microbiota e a manutenção da integridade do epitélio intestinal podem ser efeitos importantes dos extratos vegetais, como acontece com outros promotores do crescimento. 


\subsubsection{Outros efeitos dos extratos vegetais}

Em princípio, o aumento da palatabilidade da dieta, contendo extratos vegetais, poderia ser um efeito esperado. No entanto, Horton et al. (1991) detectaram queda no consumo de ração de suínos utilizando extrato de alho na dieta. Na realidade, os extratos podem afetar muito o consumo tanto positiva quanto negativamente, dependendo da composição do extrato vegetal e do seu nível de inclusão na dieta.

Os polissacarídeos contidos nos extratos de plantas chinesas como Astrangalus membranácea redix (huang oi), Lentinus edodes (shitake) e Tremella fuciformis (white jelly) podem agir como prebióticos sobre a microbiota presente no ceco de aves, melhorando o desempenho e a resistência aos patógenos (Guo et al., 2004). Este assunto ainda requer mais investigações, inclusive para suínos, mas os polissacarídeos presentes em alguns vegetais podem ser um bom modificador da microbiota intestinal.

Lima et al. (2001) observou que os extratos vegetais promovem o aumento no ganho de peso e a melhora da conversão alimentar, assim como, maior rendimento de carne na carcaça em suínos. Já as características físico-químicas e organolépticas da carne não sofrem alterações (Grela et al., 1998). 


\section{MATERIAL E MÉTODOS}

Foram conduzidos dois experimentos de 35 dias cada, na creche experimental do Setor de Suinocultura do Departamento de Zootecnia, da Escola Superior de Agricultura "Luiz de Queiroz”, da Universidade de São Paulo. O Experimento I objetivou estudar os efeitos de antimicrobianos, probióticos, prebióticos e extratos vegetais, sobre a digestibilidade dos nutrientes, a morfometria de órgãos, a histologia de epitélio intestinal e a microbiologia intestinal de leitões. Já o Experimento II avaliou o desempenho de leitões recém-desmamados alimentados com os mesmos promotores do crescimento.

\subsection{Instalações e animais}

A sala de creche, onde os animais foram alojados em ambos experimentos, possui uma área de aproximadamente $80 \mathrm{~m}^{2}$, com entradas de ar reguláveis a 1,80 $\mathrm{m}$ do solo e pé-direito de 2,8 m. Além disso, possui 20 gaiolas metálicas suspensas, dispostas em quatro faixas de cinco gaiolas (Figura 1). Cada gaiola possui uma área de 1,80 $\mathrm{m}^{2}$ (1,20 x 1,50 m), sendo providas de comedouros automáticos, bebedouro tipo chupeta e aquecimento complementar, proporcionado por lâmpadas infravermelhas de $250 \mathrm{~W}$, com a finalidade de manter a temperatura ambiente adequada aos leitões. A área encontrada abaixo do bebedouro é constituída de piso metálico vazado, enquanto que o restante é de concreto compacto, correspondente à área adjacente ao comedouro. Toda a instalação foi previamente lavada e caiada. As fezes acumuladas sob as gaiolas foram removidas diariamente.

Foram utilizados 40 leitões Dalland no Experimento I e 120 no Experimento II, todos com idades iniciais e finais de, respectivamente, 21 e 56 dias. Os animais foram adquiridos da Granja Água Branca (Itu/SP, a 80 km de Piracicaba/SP). Imediatamente após o desmame, aos 21 dias de idade, os leitões foram transportados por um caminhão dotado de carroceria de piso 
forrado com maravalha e coberta com uma lona que os protegia do vento e do sol. Ao chegar às instalações experimentais, os leitões foram pesados e distribuídos nas baias.

\begin{tabular}{|c|c|c|c|}
\hline Bloco 1 & Bloco 2 & Bloco 3 & Bloco 4 \\
\hline Baia 5 & Baia 10 & Baia 15 & Baia 20 \\
\hline Baia 4 & Baia 9 & Baia 14 & Baia 19 \\
\hline Baia 3 & Baia 8 & Baia 13 & Baia 18 \\
\hline Baia 2 & Baia 7 & Baia 12 & Baia 17 \\
\hline Baia 1 & Baia 6 & Baia 11 & Baia 16 \\
\hline
\end{tabular}

Entrada

FIGURA 1- Croqui da creche experimental do Setor de Suinocultura do Departamento de Zootecnia da ESALQ/USP

\subsection{Tratamentos}

Foram testados cinco tratamentos em ambos os experimentos:

- Tratamento controle: dieta basal;

- Tratamento antimicrobiano: dieta basal +50 ppm bacitracina de zinco +50 ppm de olaquindox;

- Tratamento probiótico: dieta basal + 1300 ppm de probiótico a base de Bacillus subtilis e Bacillus licheniformis (4,16 bilhões de esporos viáveis por kg de ração);

- Tratamento prebiótico: dieta basal + 3000 ppm de mananoligossacarídeo;

- Tratamento extrato vegetal: dieta basal + 500 ppm extrato vegetal (mistura de alho, cravo, canela, pimenta, tomilho, cinamaldeído e eugenol).

Os antimicrobianos, o probiótico, o prebiótico e os extratos vegetais foram selecionados de acordo com o perfil de contaminação das instalações. Foram identificados Streptococcus spp., Staphylococcus spp., E.coli, Campylobacter coli e Clostridium perfringens a partir de amostras de conteúdo intestinal de dois animais (um sadio e um com forte diarréia) com 35 dias de idade e que já se encontravam instalados na creche experimental desde os 21 dias de idade. 
Os antimicrobianos foram doados pela empresa Nutron Alimentos Ltda. O probiótico, cujo nome comercial é Bio Plus 2B e foi fornecido pela empresa Chr. Hansen Insústria e Comécio Ltda., enquanto o prebiótico, comercialmente chamado Bio-Mos, foi doado pela Alltech do Brasil Agroindustrial Ltda.

\subsubsection{Preparo e caracterização do extrato vegetal}

O extrato vegetal foi produzido em conjunto com o Laboratório de Tecnologia de Partículas do Instituto de Pesquisas Tecnológicas da Universidade de São Paulo (IPT/USP), que é coordenado pela pesquisadora Dra. Maria Inês Ré. O óleo-resina de pimenta, os óleos essenciais (alho, cravo, canela e tomilho), os princípios ativos (eugenol e cinamaldeído) e o material encapsulante (maltodextrina e encapsol), foram doados pela empresa Givaudan do Brasil Ltda.

Como os princípios ativos dos óleos essenciais são altamente voláteis, foi necessário que os mesmos fossem submetidos a um processo de microencapsulamento. $\mathrm{O}$ microencapsulamento em maltodextrina, utilizado neste projeto, garante a presença dos componentes ativos na ração até o momento da ingestão pelos animais. Assim que há o contato com a saliva do animal, essas substâncias são liberadas, permitindo que o animal sinta o sabor.

Primeiramente, foi feita a emulsão dos óleos essenciais, óleo-resina e princípios ativos, na proporção indicada na Tabela 1. Posteriormente, foram acrescentados a maltodextrina e o encapsol. Toda a mistura seguiu para o "spray-dryer", finalizando o processo de microencapsulamento. As microcápsulas, ao final do processo de secagem, apresentavam 12,5\% da emulsão de óleos e princípios ativos. A Tabela 2 mostra a concentração de cada substância na dieta, considerando a inclusão de 500 ppm de produto final microencapsulado (extrato vegetal).

Tabela 1. Proporção das substâncias componentes na emulsão

\begin{tabular}{lc}
\hline Substância & $\mathbf{\%}$ \\
\hline Óleo essencial de canela & 10 \\
Óleo essencial de cravo & 10 \\
Óleo essencial de alho & 20 \\
Óleo essencial de tomilho & 20 \\
Óleo-resina de pimenta $^{1}$ & 20 \\
Cinamaldeído $^{1}$ & 10 \\
Eugenol $^{2}$ & 10 \\
TOTAL $^{1}$ & 100 \\
\hline
\end{tabular}

\footnotetext{
${ }^{1}$ Principal princípio ativo da canela.
}

${ }^{2}$ Principal princípio ativo do cravo. 
Tabela 2. Concentração das substâncias componentes do extrato vegetal na dieta, considerando a inclusão de 500 ppm de extrato vegetal

\begin{tabular}{lc}
\hline Substância & Concentração em ppm na dieta \\
\hline Óleo essencial de canela & 6,25 \\
Óleo essencial de cravo & 6,25 \\
Óleo essencial de alho & 12,50 \\
Óleo essencial de tomilho & 12,50 \\
Óleo-resina de pimenta & 12,50 \\
Cinamaldeído $^{1}$ & 6,25 \\
Eugenol $^{2}$ & 6,25 \\
TOTAL & 62,50 \\
\hline
\end{tabular}

${ }^{1}$ Principal princípio ativo da canela.

${ }^{2}$ Principal princípio ativo do cravo.

\subsubsection{Testes de aceitabilidade/consumo}

Foram feitos dois testes de aceitabilidade para estimar o consumo de ração com extratos vegetais pelos animais. Os testes, realizados na própria creche experimental, testaram níveis de inclusão de 0 a 700 ppm de extrato vegetal na dieta de leitões de 21 e 60 dias de idade. Cada teste foi realizado num período de sete dias, sendo utilizada a dieta para leitões do próprio Setor de Suinocultura do Departamento de Zootecnia da ESALQ/USP. As Tabelas 3 e 4 mostram o esquema e os resultados obtidos nos testes 1 e 2, respectivamente. A partir desses resultados, estimou-se que 500 ppm poderia ser considerado o nível adequado de inclusão do extrato vegetal na dieta.

Tabela 3. Resultados do teste 1 de aceitabilidade/consumo

\begin{tabular}{cccc}
\hline Bloco & Baia ${ }^{1}$ & Tratamento $^{2}$ & Consumo diário de ração (kg)/leitão $^{*} \mathrm{P}^{3}$ \\
& 01 & 0 & 0,146 \\
& 02 & 100 & 0,128 \\
& 03 & 200 & 0,088 \\
& 04 & 300 & 0,075 \\
& 05 & 400 & 0,161 \\
& 06 & 0 & 0,718 \\
$\mathrm{G}^{4}$ & 07 & 100 & 0,849 \\
& 08 & 200 & 0,774 \\
& 09 & 300 & 0,884 \\
& 10 & 400 & 0,750
\end{tabular}

${ }^{1}$ Dois animais por baia (um macho castrado e uma fêmea).

${ }^{2}$ Inclusão, em ppm, de extrato vegetal na dieta.

${ }^{3}$ Bloco experimental com 20 leitões pequenos, aos 21 dias de idade, e peso médio de 4,8 kg.

${ }^{4}$ Bloco experimental com 20 leitões grandes, aos 60 dias de idade, e peso médio de 19,8 kg. 
Tabela 4. Resultados do teste 2 de aceitabilidade/consumo

\begin{tabular}{cccc}
\hline Bloco & Baia $^{\mathbf{1}}$ & Tratamento $^{\mathbf{2}}$ & Consumo diário de ração (kg)/leitão $^{-}$ \\
& 01 & 0 & 0,280 \\
$\mathrm{P}^{3}$ & 02 & 400 & 0,225 \\
& 03 & 500 & 0,365 \\
& 04 & 600 & 0,200 \\
& 05 & 700 & 0,227 \\
& 06 & 0 & 0,884 \\
$\mathrm{G}^{4}$ & 07 & 400 & 0,918 \\
& 08 & 500 & 0,988 \\
& 09 & 600 & 0,885 \\
& 10 & 700 & 1,039
\end{tabular}

${ }^{1}$ Dois animais por baia (um macho castrado e uma fêmea)

${ }^{2}$ Inclusão, em ppm, de extrato vegetal na dieta.

${ }^{3}$ Bloco experimental com 20 leitões pequenos, aos 21 dias de idade, e peso médio de 4,7 kg.

${ }^{4}$ Bloco experimental com 20 leitões grandes, aos 60 dias de idade, e peso médio de 18,7 kg.

\subsection{Dietas basais}

Em ambos experimentos, foram utilizadas duas dietas basais durante o período experimental. A dieta basal pré-inicial foi fornecida do $1^{\circ}$ ao $14^{\circ}$ dia de experimento, enquanto que a dieta basal inicial, do $15^{\circ}$ ao $35^{\circ}$ dia. Os níveis de exigência nutricional foram estabelecidos segundo recomendações de Rostagno et al. (2000). As composições percentuais das dietas basais, assim como os valores calculados de alguns nutrientes, podem ser encontrados na Tabela 5. 
Tabela 5. Composição percentual e valores calculados das dietas basais

\begin{tabular}{|c|c|c|}
\hline Ingrediente & $\begin{array}{c}\text { Dieta pré-inicial } \\
\text { (1-14 dias) }\end{array}$ & $\begin{array}{l}\text { Dieta inicial } \\
\text { (15-35 dias) }\end{array}$ \\
\hline Milho & 53,80 & 61,72 \\
\hline Farelo de soja (46\%) & 19,00 & 25,00 \\
\hline Óleo soja & 0,87 & 1,64 \\
\hline Fosfato bicálcico & 1,25 & 1,49 \\
\hline Calcário & 1,05 & 1,02 \\
\hline Soro de leite em pó (40\% de lactose) ${ }^{1}$ & 10,50 & 2,30 \\
\hline Soro de leite em pó (70\% de lactose) ${ }^{2}$ & 1,00 & 1,00 \\
\hline Lactose & 7,00 & 2,42 \\
\hline Plasma sanguíneo & 4,00 & 2,00 \\
\hline L-LisinaHCl ${ }^{3}$ & 0,47 & 0,38 \\
\hline L-Treonina $^{4}$ & 0,18 & 0,14 \\
\hline L-Triptofano ${ }^{5}$ & 0,06 & 0,00 \\
\hline DL-Metionina $^{6}$ & 0,21 & 0,13 \\
\hline Sal & -- & 0,15 \\
\hline Antioxidante BHT & 0,01 & 0,01 \\
\hline Cloreto de colina (60\%) & 0,10 & 0,10 \\
\hline Suplemento mineral $^{7}$ & 0,10 & 0,10 \\
\hline Suplemento vitamínico $^{8}$ & 0,10 & 0,10 \\
\hline Caulim e/ou promotor do crescimento & 0,30 & 0,30 \\
\hline \multicolumn{3}{|l|}{ Valores calculados: } \\
\hline Energia metabolizável (kcal/kg) & 3.400 & 3.300 \\
\hline Proteína bruta (\%) & 20,00 & 19,50 \\
\hline Lisina total (\%) & 1,50 & 1,33 \\
\hline Lisina digestível (\%) & 1,34 & 1,19 \\
\hline Treonina digestível (\%) & 0,86 & 0,77 \\
\hline Triptofano digestível (\%) & 0,27 & 0,21 \\
\hline Metionina digestível (\%) & 0,46 & 0,39 \\
\hline Metionina + cistina digestível (\%) & 0,79 & 0,69 \\
\hline Lactose (\%) & 11,76 & 4,00 \\
\hline Cálcio (\%) & 0,85 & 0,87 \\
\hline Fósforo disponível (\%) & 0,45 & 0,42 \\
\hline
\end{tabular}

${ }^{1}$ Produto comercial chamado Nuklospray K-10.

${ }^{2}$ Produto comercial chamado Nuklospray K-21.

${ }^{3}$ Contendo $78 \%$ L-Lisina.

${ }^{4}$ Contendo 98,5\% L-Treonina.

${ }^{5}$ Contendo 98\% L-Triptofano.

${ }^{6}$ Contendo 99\% DL-Metionina.

${ }^{7}$ Quantidades supridas por kg de ração: vit. A, 6000 UI; vit. $\mathrm{D}_{3}, 1500$ UI; vit. E, 15 UI; vit. $\mathrm{K}_{3}, 1,5$ mg; tiamina, 1,35 mg; riboflavina, 4 mg; piridoxina, 2 mg; vit. $\mathrm{B}_{12}, 0,02 \mathrm{mg}$; ácido nicotínico, $20 \mathrm{mg}$; ácido fólico, 0,6 mg; biotina, 0,8 mg; ácido pantotênico, 9,35 mg; selênio 0,3 mg.

${ }^{8}$ Quantidades supridas por kg de ração: iodo, 1,5 mg; cobalto, $1 \mathrm{mg}$; cobre, $10 \mathrm{mg}$; zinco $100 \mathrm{mg}$; ferro, $100 \mathrm{mg}$; manganês, $40 \mathrm{mg}$. 


\subsection{Experimento I}

Foram utilizados 40 leitões Dalland de 21 dias de idade com peso médio inicial e final de, respectivamente, 5,87 kg e 17,94 kg, distribuídos em 20 baias (dois animais por baia) de acordo com o peso, totalizando quatro blocos (quatro repetições por tratamento). Os animais foram alimentados à vontade durante todo o período experimental de 35 dias. Durante os últimos 14 dias do Experimento I, foi realizado o ensaio de digestibilidade e, no $35^{\circ}$ dia do experimento, o abate dos animais para coleta de dados referentes a morfometria de órgãos e para coleta de amostras para análises microbianas e histológicas.

\subsubsection{Morfometria dos órgãos}

Após o sacrifício de cada animal (um animal por unidade experimental), no 35 dia do Experimento I, a cavidade abdominal foi aberta por incisão longitudinal, retirando e pesando os órgãos digestivos (trato gastrintestinal total, estômago vazio, pâncreas, fígado, vesícula biliar, intestino delgado vazio, intestino grosso vazio, ceco e colo vazios) e os não digestivos (baço, rins, pulmões e coração). Também foi feita a medição do comprimento do intestino delgado dos animais. De posse dos dados, foram calculados os pesos relativos dos órgãos, o comprimento relativo e a relação peso:comprimento do intestino delgado.

\subsubsection{Histologia do epitélio intestinal}

\subsubsection{Microscopia ótica}

Imediatamente após a retirada e pesagem do trato gastrintestinal, segmentos de cerca de $5 \mathrm{~cm}$ de comprimento do duodeno (até $15 \mathrm{~cm}$ do esfíncter estomacal), jejuno (1,5 m da junção do íleo com o intestino grosso) e íleo (20 cm da junção com o intestino grosso) foram retirados, abertos ao longo do mesentério, fixados em papelão com grampos e acondicionados em líquido fixador de Bouin. As amostras fixadas em solução de Bouin foram transportadas para o Laboratório de Citologia, Histologia e Embriologia do Departamento de Ciências Básicas da Faculdade de Zootecnia e Engenharia de Alimentos da Universidade de São Paulo (FZEA/USP), onde foram emblocadas em historesina. Após a secagem dos blocos, foram feitos os cortes histológicos de $3 \mu \mathrm{m}$ em micrótomo automático. 
Para cada amostra, foram recolhidos cinco cortes não seriados (intervalados por 30 cortes) em uma lâmina e outros dois cortes, também não seriados, em uma segunda lâmina. As lâminas com cinco cortes foram submetidas à coloração por hematoxilina e eosina. Já as outras lâminas (com dois cortes) foram coradas através da reação histoquímica PAS - ácido periódico-reativo de Schiff (Lillie \& Fullmer, 1976).

As medições foram feitas através de imagens geradas em um microscópio ZEISS Axioplan 2 e captadas digitalmente por uma câmera. O software utilizado para a análise das imagens foi o KS 400, sendo este capaz de fazer medições de comprimentos e áreas.

As lâminas coradas com hematoxilina/eosina foram utilizadas para a análise de altura de vilosidade, profundidade de cripta, relação altura de vilosidade/profundidade de cripta e porcentagem de área ocupada por células caliciformes no epitélio intestinal, de acordo com metodologia descrita por Jin et al. (1994).

\subsubsection{Microscopia eletrônica de varredura}

Das mesmas amostras, coletadas para a análise histológica em microscopia ótica (duodeno, jejuno e íleo), foram retiradas amostras de $0,25 \mathrm{~cm}^{2}(0,50 \times 0,50 \mathrm{~cm})$ para análise em microscopia eletrônica de varredura. No momento da coleta, foram lavadas, mergulhadas em solução fixadora de Karnovisk (duas horas) e armazenadas em definitivo em solução tampão fosfato 0,1 M (temperatura de $3^{\circ} \mathrm{C}$ ). Em um segundo momento, foram transportadas ao Núcleo de Apoio à Pesquisa / Microscopia Eletrônica Aplicada à Pesquisa Agropecuária (NAP/MEPA) da ESALQ/USP, onde foram pós-fixadas em tetróxido de ósmio $\left(\mathrm{OsO}_{4}\right)$. Ao final da fixação foi feita a secagem ao ponto crítico, a metalização das amostras e a visualização em um microscópio eletrônico de varredura em pressão variável LEO 435 VP. Foram obtidas três eletronmicrografias de campos distintos (tréplicas) de cada amostra. A partir destas imagens, foram feitas as contagens do número de vilosidades dentro de um determinado campo, cuja área era conhecida. A densidade de vilosidades para cada animal foi obtida pela média do número de vilosidades/1.000.000 $\mu \mathrm{m}^{2}$. 


\subsubsection{Microbiologia intestinal}

Durante a retirada das amostras de epitélio intestinal para as análises histológicas, foram coletados, separadamente, os conteúdos do jejuno/íleo e do reto pelo método de raspagem. As amostras de conteúdo intestinal do jejuno/íleo foram armazenadas em eppendorfs de $1,5 \mathrm{ml}$, os quais foram acondicionados em caixa térmica a $5^{\circ} \mathrm{C}$. Já as amostras de conteúdo do reto (análise de Clostridium perfringens) foram depositadas em potes plásticos de $50 \mathrm{ml}$, que foram acondicionados em jarras de anaerobiose, providas de geradores de $\mathrm{CO}_{2}$, em temperatura ambiente. Após a coleta, as amostras seguiram para os laboratórios localizados no Campus da USP e no Instituto Biológico, em São Paulo, para posterior análise.

O procedimento laboratorial para análise de microrganismos totais, grampositivos totais, gram-negativos totais, Bacillus spp., Streptococcus spp., Staphylococcus spp., Salmonella spp. e E.coli foi realizado no Laboratório de Doenças Infecciosas - Bactérias e Fungos, do Departamento de Medicina Veterinária Preventiva e Saúde Animal da Faculdade de Medicina Veterinária e Zootecnia da Universidade de São Paulo (FMVZ/USP.), com a colaboração da Médica Veterinária Priscilla Anne Maelville e do Prof. Dr. Nilson Roberti Benites. Foram adotadas técnicas de plaqueamento (Lennette et al., 1985; Krieg \& Holt, 1994), nas quais as amostras foram semeadas em ágar Mac Conkey e ágar sangue e, posteriormente, foram submetidas a provas bioquímicas (catalase e manitol).

A identificação e quantificação do gênero Campylobacter coli. foi feita no Laboratório de Doenças Bacterianas da Reprodução, no Centro de Pesquisa e Desenvolvimento de Sanidade Animal do Instituto Biológico, com a colaboração da Dra. Eliana Scarcelli. Foi utilizada a técnica descrita por Scarcelli et al. (1998).

A fase laboratorial correspondente à identificação (isolamento) e quantificação de Clostridium perfringens foi realizada no Laboratório de Microbiologia Oral - Anaeróbios, do Departamento de Microbiologia do Instituto de Ciências Biomédicas da Universidade de São Paulo (ICB/USP), com a colaboração do Prof. Dr. Mário Júlio Ávila Campos. Também foi utilizada a técnica de plaqueamento em meio de cultura específico, mas com incubação em condições de anaerobiose, de acordo com Bressani (2001). A identificação da espécie $C$. perfringens foi feita por observação da morfometria colonial e por provas de coloração de gram, produção de lipase, lecitinase, catalase, $\mathrm{H}_{2} \mathrm{~S}$ e indol, hidrólise da gelatina, esculina e amido, localização do esporo e fermentação dos carboidratos em caldo peptona extrato de levedura. 


\subsubsection{Digestibilidade aparente dos nutrientes}

Foi empregado o método da coleta parcial de fezes, descrito por Moreira (1993), utilizando-se o óxido crômico $\left(\mathrm{Cr}_{2} \mathrm{O}_{3}\right)$ como marcador, adicionado às dietas experimentais na concentração de $0,1 \%$. A ração marcada foi fornecida a partir do $21^{\circ}$ dia do Experimento I, havendo tempo suficiente para que a mesma preenchesse todo o trato gastrintestinal antes do período de coleta de fezes ( $30^{\circ}$ ao $34^{\circ}$ dia). Não houve restrição alimentar para não causar nenhum prejuízo no desempenho dos animais.

As amostras de fezes (200 g, aproximadamente) foram coletadas duas vezes ao dia (8:00 e 17:00 h) do reto dos animais, sendo imediatamente acondicionadas e congeladas em sacos plásticos transparentes identificados.

Ao final do Experimento I, as amostras de fezes foram descongeladas e homogeneizadas, retirando-se uma subamostra de $600 \mathrm{~g}$. Estas subamostras foram secas em estufas de circulação de ar forçada, a $65^{\circ} \mathrm{C}$ e durante 72 horas, e moídas em moinho tipo Willey, em peneira crivada de $1 \mathrm{~mm}$. As amostras moídas foram enviadas junto com as amostras de rações para análises bromatológicas (matéria seca, proteína bruta e energia bruta) e de óxido crômico.

A percentagem de óxido crômico nas fezes e nas dietas foi determinada pela técnica analítica instrumental de fluorescência de raio X por dispersão de energia (Zucchi \& Nascimento Filho, 1995; Nascimento Filho et al., 1997), sendo as análises realizadas no Laboratório de Instrumentação Nuclear do Centro de Energia Nuclear na Agricultura (CENA/USP), com a colaboração do Prof. Dr. Virgílio Nascimento Filho.

Já as análises bromatológicas foram realizadas no Laboratório de Bromatologia do Departamento de Zootecnia da Faculdade de Zootecnia e Engenharia de Alimentos da Universidade de São Paulo (FZEA/USP), em Pirassununga/SP. A determinação de energia bruta foi feita em bomba calorimétrica automática modelo PARR 1261. As análises de matéria seca e proteína bruta foram realizadas de acordo com a Association of Official Analytical Chemists (AOAC, 1980). Todas as amostras foram analisadas em duplicata. 
Para se obterem os coeficientes de digestibilidade aparente de matéria seca, energia bruta e proteína bruta, os resultados das análises bromatológicas e de cromo das rações e fezes foram calculados em base de matéria seca e submetidos à equação de Matterson et al. (1965):

$$
\text { CDap }(\%)=100-100 \times \frac{(\% \text { marcador na dieta })}{(\% \text { marcador nas fezes })} \times \frac{(\% \text { nutriente nas fezes })}{(\% \text { nutriente na dieta })},
$$

onde:

CDap = Coeficiente de digestibilidade aparente

\subsection{Experimento II}

Foram utilizados 120 leitões Dalland, com 21 dias de idade e 6,04 kg de peso médio inicial, distribuídos em 60 baias (dois animais por baia) de acordo com o sexo e o peso, totalizando 12 blocos (12 repetições por tratamento). No entanto, como a Creche Experimental possui apenas 20 baias, foram realizadas três repetições no tempo (4 blocos por repetição no tempo). As temperaturas máximas e mínimas diárias foram monitoradas durante todo o experimento.

Os animais receberam água e ração à vontade. As variáveis de desempenho (consumo diário de ração, ganho diário de peso e conversão alimentar) foram calculadas a partir de pesagens e quantificações das sobras de ração feitas semanalmente.

Durante todo o Experimento II, foi também observada a incidência de diarréias, adotando o mesmo procedimento descrito por Vassalo (1995). Foi utilizado o escore de fezes atribuindo notas para cada animal, diariamente pela manhã, de 0 a 3, sendo: (0) fezes sólidas, (1) fezes pastosas, (2) fezes líquidas/pastosas e (3) fezes líquidas. Apenas os escores 2 e 3 indicavam a ocorrência de diarréia. Assim, pôde-se calcular a porcentagem de dias com ocorrência de diarréia nos períodos de um a 14, 15 a 35 e um a 35 dias de experimentação. 


\subsection{Delineamento experimental}

O delineamento experimental utilizado foi o de blocos casualizados para ambos experimentos. O Experimento I contou com 5 tratamentos e 4 repetições (blocos) por tratamento, enquanto que o Experimento II foi composto por 5 tratamentos e 12 repetições (blocos) por tratamento.

\subsection{Análise dos dados}

Os dados referentes à morfometria de órgãos, histologia intestinal, digestibilidade aparente dos nutrientes e desempenho foram submetidos aos testes de adequação ao modelo linear e, posteriormente, à análise de variância, pelo PROC GLM (General Linear Models) do SAS (Statistical Analysis System, 2001). A comparação de médias foi feita pelo teste de Tukey.

Os dados referentes à microbiologia intestinal, originalmente em "ufc/g" (unidades formadoras de colônias/g de amostra), foram transformados pela função $y=\log x$, onde $x$ é o número de unidades formadoras de colônias/g (ufc/g). Já os dados de freqüência de

diarréia, em \%, foram transformados pela função $y=\operatorname{arcsen} \sqrt{(p / 100)}$, de acordo com o recomendado por Barbin (2003). Posteriormente, foram submetidos aos testes de adequação ao modelo linear, à análise de variâncias (PROC GLM do SAS 2001) e à comparação de médias, pelo teste de Tukey. 


\section{RESULTADOS E DISCUSSÃO}

\subsection{Experimento I}

\subsubsection{Morfometria dos órgãos}

A Tabela 6 apresenta as médias dos pesos relativos (em percentagem do peso vivo) dos órgãos digestórios e não digestórios, assim como do comprimento, do comprimento relativo e da relação peso:comprimento do intestino delgado, em função dos tratamentos. Já as Tabelas A2 e A3 (Apêndice) apresentam os pesos absolutos dos órgãos, por unidade experimental, enquanto as Tabelas A4 e A5 (Apêndice) apresentam os pesos relativos (em percentagem do peso vivo) dos órgãos. Apenas o pâncreas, o coração e os rins tiveram seus pesos relativos significativamente $(\mathrm{P}<0,05)$ influenciados pelos tratamentos. As demais variáveis não sofreram efeitos significativos $(\mathrm{P}>0,10)$ dos tratamentos.

O tratamento antimicrobiano aumentou $(\mathrm{P}<0,05)$ o peso relativo do coração, em relação ao tratamento probiótico, e dos rins, em relação aos tratamentos probiótico e prebiótico. Este resultado contraria o que se constata na literatura a respeito do efeito de antimicrobianos sobre os órgãos. Tannock (1997) relatou que os antimicrobianos propiciam uma redução do peso relativo de órgãos como coração, pulmão e fígado, pois há um menor estímulo do sistema retículo-endotelial do que quando da presença normal de antígenos.

O peso relativo vazio, o comprimento, o comprimento relativo e a relação peso:comprimento do intestino delgado, assim como o peso relativo do trato gastrintestinal total, não foram significativamente $(\mathrm{P}>0,05)$ influenciados pelos tratamentos. Apesar de não significativa $(\mathrm{P}>0,05)$, é importante ressaltar a menor relação peso:comprimento (densidade) do intestino delgado dos animais do tratamento extrato vegetal em relação aos demais tratamentos. Esta redução da densidade do intestino delgado, causada pelo tratamento extrato vegetal, pode 
ser causada por restrição no consumo de ração, pois é justamente a ingestão de alimentos o que mais influencia a massa intestinal (Burrin et al., 2001).

Tabela 6. Médias dos pesos relativos (percentagem do peso vivo) dos órgãos digestórios e não digestórios, assim como do comprimento, do comprimento relativo e da relação peso:comprimento do intestino delgado, em função dos tratamentos (Experimento I)

\begin{tabular}{|c|c|c|c|c|c|c|c|c|}
\hline \multirow[b]{2}{*}{ Órgão } & \multicolumn{5}{|c|}{ Tratamentos $^{1}$} & \multirow{2}{*}{ Média } & \multirow{2}{*}{$\operatorname{Pr}>F$} & \multirow{2}{*}{$\begin{array}{l}\mathrm{CV}^{2} \\
(\%)\end{array}$} \\
\hline & C & A & PO & PE & $\mathrm{E}$ & & & \\
\hline $\begin{array}{l}\text { Trato gastrintestinal } \\
\text { total }(\%)\end{array}$ & 22,85 & 20,95 & 21,09 & 20,25 & 22,41 & $21,50 \pm 2,36$ & 0,5247 & 10,96 \\
\hline Estômago vazio (\%) & 0,75 & 0,70 & 0,68 & 0,77 & 0,76 & $0,73 \pm 0,08$ & 0,5590 & 11,49 \\
\hline Pâncreas (\%) ${ }^{7}$ & $0,20 \mathrm{ab}$ & $0,21 \mathrm{ab}$ & $0,15 \mathrm{~b}$ & $0,16 \mathrm{~b}$ & 0,25 a & $0,19 \pm 0,06$ & 0,0512 & 20,07 \\
\hline Fígado (\%) & 2,87 & 3,01 & 2,95 & 2,80 & 3,05 & $2,93 \pm 0,31$ & 0,7340 & 9,50 \\
\hline Vesícula biliar (\%) & 0,056 & 0,047 & 0,084 & 0,057 & 0,053 & $0,059 \pm 0,02$ & 0,2884 & 40,32 \\
\hline $\mathrm{ID}^{3}$ vazio (\%) & 4,99 & 4,24 & 4,78 & 4,60 & 4,66 & $4,65 \pm 0,46$ & 0,2687 & 9,80 \\
\hline Intestino grosso vazio (\%) & 2,39 & 2,08 & 2,20 & 2,12 & 2,35 & $2,23 \pm 0,40$ & 0,6743 & 16,19 \\
\hline Ceco vazio (\%) & 0,19 & 0,15 & 0,18 & 0,14 & 0,18 & $0,17 \pm 0,03$ & 0,3272 & 21,18 \\
\hline Colo vazio (\%) & 2,20 & 1,928 & 2,01 & 1,97 & 2,17 & $2,05 \pm 0,40$ & 0,7773 & 17,96 \\
\hline Pulmão (\%) & 1,420 & 1,607 & 1,517 & 1,277 & 1,595 & $1,48 \pm 0,30$ & 0,5377 & 20,47 \\
\hline Coração (\%) $)^{7}$ & $0,55 \mathrm{ab}$ & $0,60 \mathrm{a}$ & $0,49 \mathrm{~b}$ & $0,50 \mathrm{ab}$ & $0,54 \mathrm{ab}$ & $0,54 \pm 0,05$ & 0,0373 & 8,30 \\
\hline Rins $(\%)^{7}$ & $0,60 \mathrm{ab}$ & 0,69 a & $0,58 \mathrm{~b}$ & $0,53 \mathrm{~b}$ & $0,61 \mathrm{ab}$ & $0,60 \pm 0,06$ & 0,0061 & 7,95 \\
\hline Baço (\%) & 0,21 & 0,21 & 0,16 & 0,18 & 0,17 & $0,19 \pm 0,03$ & 0,1132 & 14,82 \\
\hline Comprimento $\mathrm{ID}^{4}(\mathrm{~m})$ & 12,050 & 13,137 & 12,690 & 12,700 & 12,312 & $12,57 \pm 1,19$ & 0,8183 & 10,70 \\
\hline Comp. rel. ID ${ }^{5}$ (m/kg PV) & 0,694 & 0,580 & 0,661 & 0,652 & 0,688 & $0,665 \pm 0,07$ & 0,3209 & 12,09 \\
\hline Relação P:C ID ${ }^{6}$ (g/m) & 72,935 & 73,171 & 72,824 & 70,683 & 67,756 & $71,47 \pm 5,86$ & 0,7463 & 9,26 \\
\hline $\begin{array}{l}1 \mathrm{C}=\text { controle; } \mathrm{A}=\text { antimicrobia } \\
{ }^{2} \text { Coeficiente de variação. } \\
{ }^{3} \text { Intestino delgado vazio. } \\
{ }^{4} \text { Comprimento do intestino d } \\
{ }^{5} \text { Comprimento relativo do in } \\
{ }^{6} \text { Relação peso:comprimento }\end{array}$ & do. & P. & F-nobít & ico; e E $=e$ & & & & \\
\hline
\end{tabular}

Houve, também, uma redução numérica não significativa $(\mathrm{P}>0,05)$ no peso relativo dos intestinos delgado e grosso (ceco e cólon) vazios dos animais do tratamento antimicrobiano. Essa redução não pode ser atribuída à menor espessura da parede intestinal, pois a relação peso:comprimento do intestino delgado não foi reduzida $(P>0,05)$. Na realidade, o menor peso relativo do intestino delgado está diretamente relacionado ao menor valor do comprimento relativo, também não significativo $(\mathrm{P}>0,05)$. Pode-se sugerir, então, que pode ter havido uma menor fermentação microbiana, pois a fermentação microbiana produz ácidos 
graxos voláteis, os quais fornecem boa parte da energia exigida para os enterócitos (Lin \& Visek, 1991). No cólon, até 60-70\% da energia utilizada pelas células epiteliais provêm dos produtos da fermentação microbiana (Cummings \& Macfarlane, 1991). Sendo assim, se houve menor produção de ácidos graxos voláteis, pode ter havido, também, uma menor taxa de replicação celular no epitélio intestinal de leitões do tratamento antimicrobiano, levando à redução dos pesos relativos dos intestinos delgado e grosso. Já a relação peso:comprimento do intestino delgado dos animais do tratamento antimicrobiano não foi afetada, provavelmente, pela menor descamação celular. A menor descamação celular, por sua vez, pode ser atribuída à redução e/ou modulação da microbiota (Anderson et al., 1999). Além disso, uma maior ingestão de alimentos também pode ter contribuído para aumentar a densidade intestinal (Burrin et al., 2001). Portanto, apesar de reduzir os pesos relativos dos intestinos delgado e grosso, o tratamento antimicrobiano não afetou a relação peso:comprimento do intestino delgado.

Os tratamentos probiótico e prebiótico, praticamente, não causaram nenhuma modificação na morfometria dos órgãos. Houve apenas um menor $(\mathrm{P}<0,05)$ peso relativo do pâncreas dos animais de ambos tratamentos, comparado ao tratamento extrato vegetal.

O prebiótico mananoligossacarídeo é reconhecido por alguns autores (Savage et al., 1996; Ferket, 2002, 2003) como estimulador do sistema imunológico humoral, gerando economia de nutrientes (energia e proteínas) por não causar o estímulo crônico do sistema ativo de defesa, muito mais dispendioso (Humprey et al., 2002, citados por Ferket, 2003). Devido a este efeito, Ferket (2002) estudou o peso relativo do intestino delgado, baço e fígado de perus, alimentados com mananoligossacarídeo, concluindo que não houve nenhuma alteração. Os resultados do Experimento I estão de acordo com Ferket (2002), pois o tratamento prebiótico também não alterou o peso relativo destes órgãos.

Os animais do tratamento extrato vegetal apresentaram o pâncreas mais desenvolvido $(\mathrm{P}<0,10)$ do que aqueles dos tratamentos probiótico e prebiótico. Entretanto, não houve diferença $(\mathrm{P}>0,10)$ para com os tratamentos controle e antimicrobiano. Tem sido demonstrado que extratos vegetais podem aumentar a secreção de saliva, suco gástrico, suco pancreático, sais biliares e enzimas do intestino delgado em ratos (Ganesh-Baht et al., 1984; Sambaiah \& Srinivasan, 1991; Platel \& Srinivasan, 1996; Wang \& Bourne, 1998). Estes efeitos ainda não foram verificados em suínos, mas o aumento do peso relativo do pâncreas dos leitões do tratamento extrato vegetal pode ser a indicação de que pode ter havido um maior estímulo da secreção pancreática. 


\subsubsection{Histologia do epitélio intestinal}

A Tabela 7 apresenta as médias da altura das vilosidades (AV), da profundidade das criptas (PC), da relação altura de vilosidade/profundidade de cripta (AV/PC), da porcentagem de área ocupada por células caliciformes nos epitélios intestinais (\%CC) e da densidade de vilosidades (DV) no duodeno, jejuno e íleo dos leitões ao final de 35 dias de experimentação.

Tabela 7. Médias da altura das vilosidades (AV), da profundidade das criptas (PC), da relação altura de vilosidade/profundidade de cripta (AV/PC), da percentagem de área ocupada pelas células caliciformes nos epitélios intestinais (\%CC) e da densidade de vilosidades (DV) no duodeno, jejuno e íleo dos leitões ao final de 35 dias de experimentação (Experimento I)

\begin{tabular}{|c|c|c|c|c|c|c|c|c|}
\hline & \multicolumn{5}{|c|}{ Tratamentos $^{1}$} & \multirow{2}{*}{ Média } & \multirow{2}{*}{$\operatorname{Pr}>F$} & \multirow{2}{*}{$\begin{array}{l}\mathrm{CV}^{2} \\
(\%)\end{array}$} \\
\hline & $\mathrm{C}$ & A & $\mathrm{PO}$ & $\mathrm{PE}$ & $\mathrm{E}$ & & & \\
\hline \multicolumn{9}{|l|}{ DUODENO } \\
\hline $\mathrm{AV}(\mu \mathrm{m})$ & 255,32 & 314,65 & 242,89 & 292,65 & 304,01 & 281,90 & 0,5254 & 24,17 \\
\hline $\mathrm{PC}(\mu \mathrm{m})$ & 230,30 & 231,01 & 279,95 & 240,71 & 226,18 & 241,63 & 0,4236 & 17,85 \\
\hline $\mathrm{AV} / \mathrm{PC}$ & 1,40 & 1,61 & 1,11 & 1,45 & 1,56 & 1,43 & 0,6879 & 36,42 \\
\hline \%CC (\%) & 7,61 & 7,14 & 4,41 & 5,91 & 4,47 & 5,91 & 0,3028 & 42,80 \\
\hline $\mathrm{DV}^{3}$ & 34,54 & 26,96 & 24,55 & 24,60 & 30,02 & 28,13 & 0,5890 & 35,11 \\
\hline \multicolumn{9}{|l|}{ JEJUNO } \\
\hline $\mathrm{AV}(\mu \mathrm{m})$ & 241,05 & 230,29 & 246,64 & 244,85 & 299,61 & 252,48 & 0,8134 & 34,46 \\
\hline $\mathrm{PC}(\mu \mathrm{m})$ & 256,21 & 284,64 & 264,61 & 248,43 & 231,37 & 257,05 & 0,8704 & 27,85 \\
\hline $\mathrm{AV} / \mathrm{PC}$ & 1,14 & 1,09 & 1,09 & 1,17 & 1,53 & 1,20 & 0,8264 & 49,98 \\
\hline$\%$ CC $(\%)^{4}$ & 7,39 a & $4,84 \mathrm{ab}$ & $4,06 \mathrm{~b}$ & 6,68 ab & $6,72 \mathrm{ab}$ & 5,94 & 0,0214 & 22,89 \\
\hline $\mathrm{DV}^{3}$ & 36,21 & 35,91 & 45,44 & 38,48 & 41,23 & 39,45 & 0,6877 & 26,56 \\
\hline \multicolumn{9}{|l|}{ ÍLEO } \\
\hline$\overline{A V}(\mu \mathrm{m})$ & 269,97 & 263,24 & 222,67 & 214,70 & 183,80 & 230,88 & 0,4352 & 30,67 \\
\hline $\mathrm{PC}(\mu \mathrm{m})^{4}$ & $237,80 a b$ & $201,01 \mathrm{~b}$ & $284,39 a b$ & $282,49 a b$ & 303,98 a & 261,93 & 0,0381 & 16,85 \\
\hline $\mathrm{AV} / \mathrm{PC}$ & 1,33 & 1,60 & 0,92 & 1,03 & 0,72 & 1,12 & 0,1693 & 44,49 \\
\hline \%СC (\%) & 8,49 & 9,28 & 7,23 & 8,48 & 7,78 & 8,25 & 0,8508 & 32,76 \\
\hline $\mathrm{DV}^{3}$ & 41,58 & 40,43 & 33,59 & 39,39 & 33,47 & 37,69 & 0,7149 & 28,21 \\
\hline
\end{tabular}

${ }^{1} \mathrm{C}=$ controle; $\mathrm{A}=$ antimicrobiano; $\mathrm{PO}=$ probiótico; $\mathrm{PE}=$ prebiótico; e $\mathrm{E}=$ extrato vegetal.

${ }^{2}$ Coeficiente de variação.

${ }^{3}$ Densidade de vilosidades $=$ número de vilosidades $/ 1.000 .000 \mu \mathrm{m}^{2}$.

${ }^{4}$ Letras diferentes, na mesma linha, diferem significativamente pelo teste de Tukey $(\mathrm{P}<0,10)$. 
As Figuras 2, 3 e 4 apresentam, respectivamente, eletronmicrografias de varredura do duodeno, do jejuno e do íleo dos leitões aos 35 dias de experimentação.
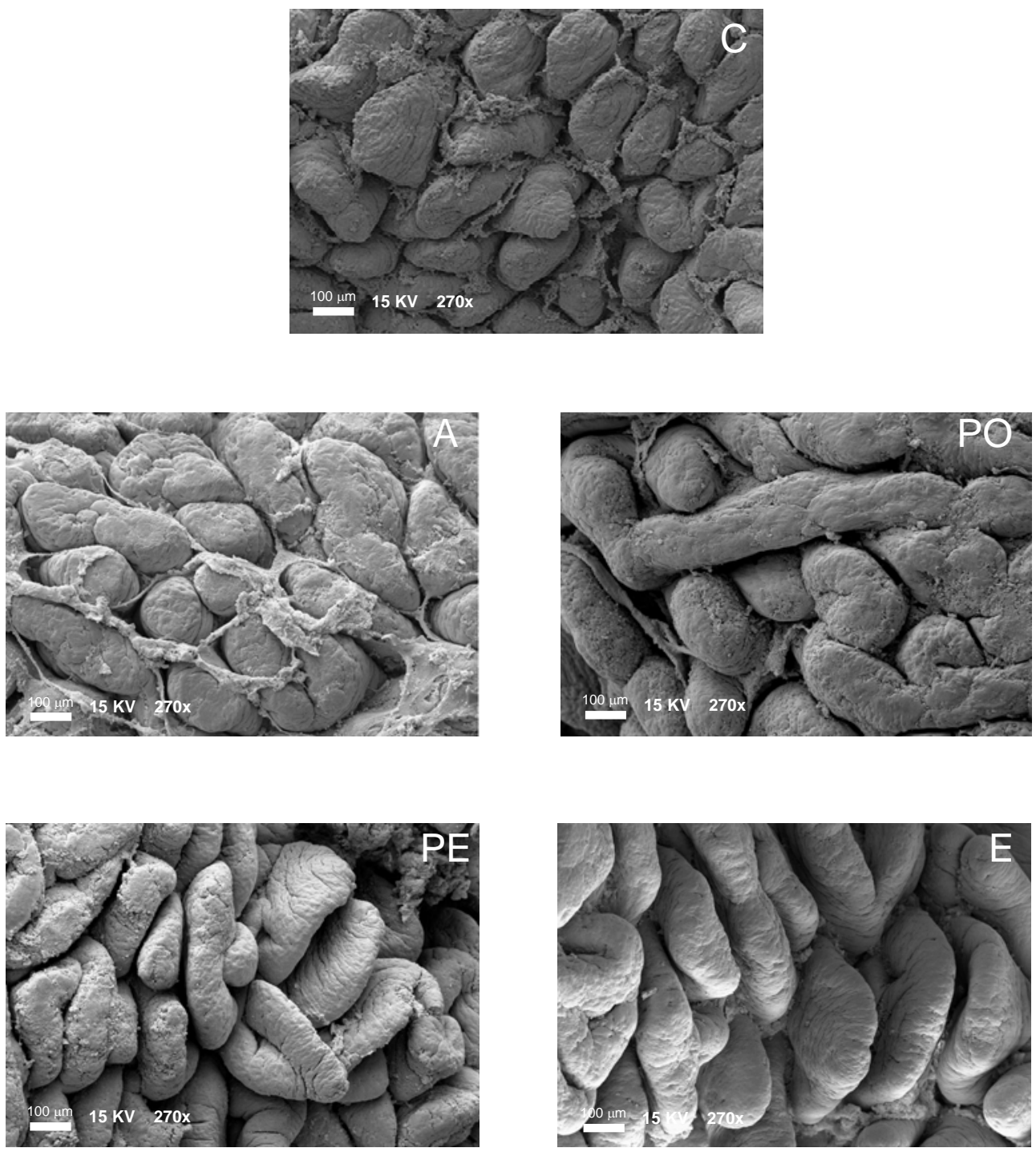

FIGURA 2 - Eletronmicrografias de varredura do duodeno dos leitões dos tratamentos controle (C), antimicrobiano (A), probiótico (PO), prebiótico (PE) e extrato vegetal (E) aos 35 dias de experimentação 

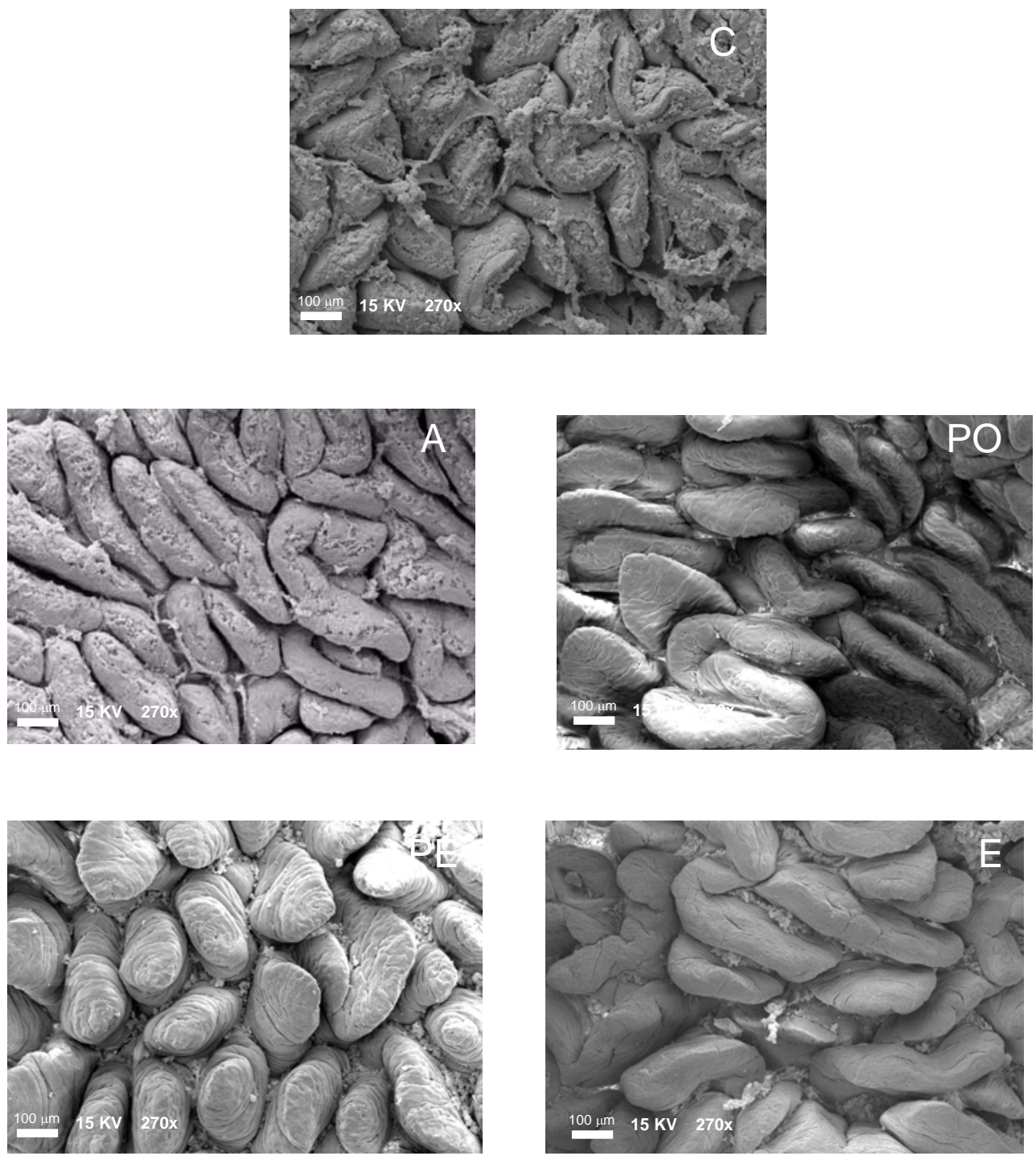

FIGURA 3 - Eletronmicrografias de varredura do jejuno dos leitões dos tratamentos controle (C), antimicrobiano (A), probiótico (PO), prebiótico (PE) e extrato vegetal (E) aos 35 dias de experimentação 

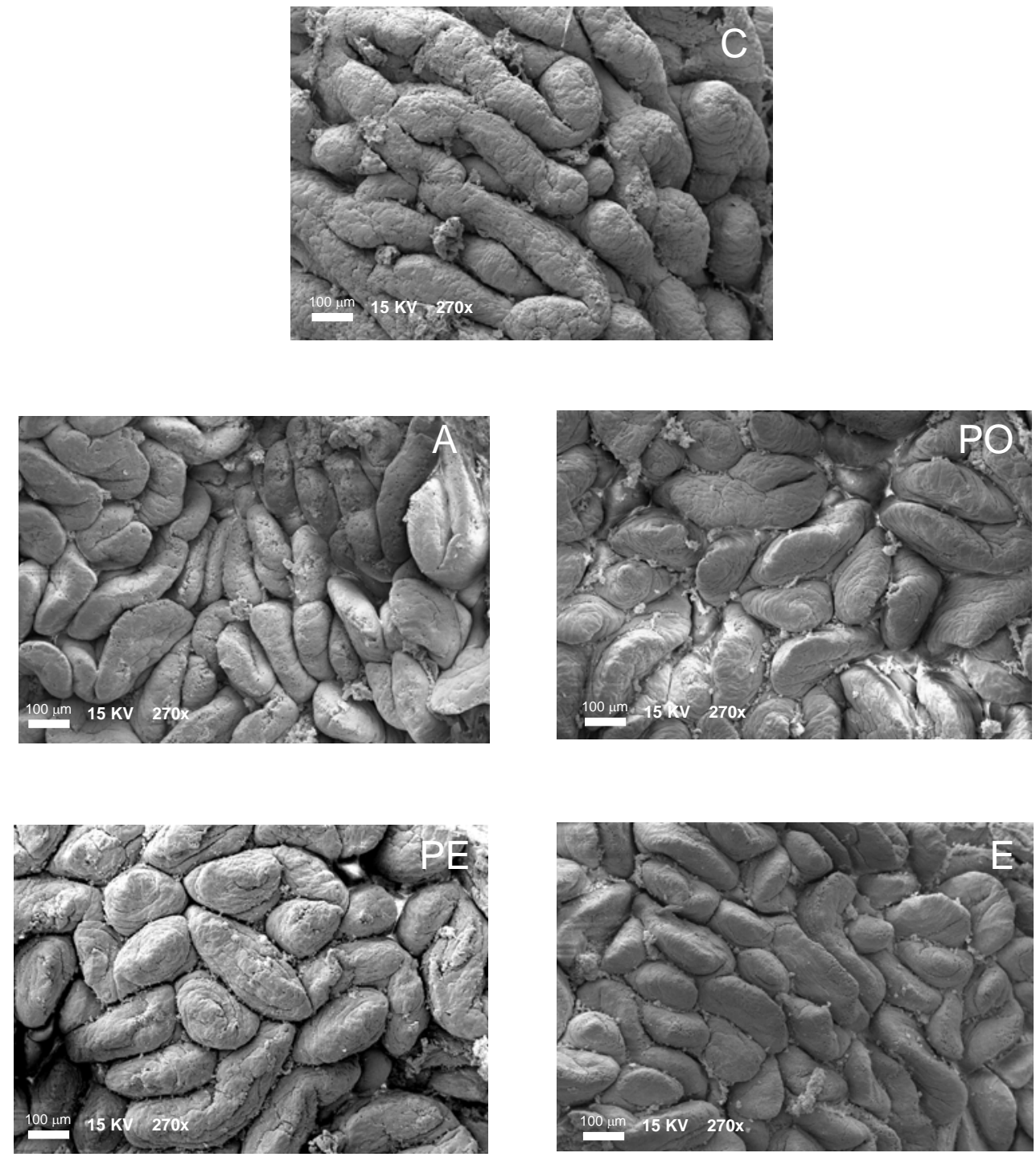

FIGURA 4 - Eletronmicrografias de varredura do íleo dos leitões dos tratamentos controle (C), antimicrobiano (A), probiótico (PO), prebiótico (PE) e extrato vegetal (E) aos 35 dias de experimentação

Apenas as variáveis profundidade de cripta (PC) do íleo e porcentagem de área ocupada pelas células caliciformes no epitélio intestinal (\%CC) do jejuno foram influenciadas $(\mathrm{P}<0,10)$ pelos tratamentos. No íleo, os animais do tratamento antimicrobiano apresentaram criptas com menor profundidade $(\mathrm{P}<0,10)$ do que os dos demais tratamentos. Contrariamente, $\mathrm{o}$ tratamento extrato vegetal proporcionou criptas com maior profundidade $(\mathrm{P}<0,10)$ no íleo. No 
jejuno, a \%CC foi maior $(\mathrm{P}<0,10)$ para os animais do tratamento controle em relação aos do tratamento probiótico.

Mesmo sem diferenças significativas $(\mathrm{P}>0,10)$, é importante ressaltar que, no duodeno, os tratamentos antimicrobiano, prebiótico e extrato vegetal proporcionaram efeitos positivos sobre o epitélio intestinal, apresentando maior AV e AV/PC e menor PC e \%CC, em relação ao tratamento controle. Já o tratamento probiótico proporcionou resultados semelhantes ao tratamento controle.

No período pós-desmame, há, normalmente, atrofia dos vilos, causada principalmente pelo aumento na taxa de descamação. O aumento na taxa de descamação é consequência do início do consumo de ração sólida, de toxinas bacterianas e da adesão de bactérias aos enterócitos (Cera, 1988). O aumento na descamação leva a um aumento na proliferação celular da cripta (Tucci, 2003). A maior profundidade de cripta é consequência da maior atividade proliferativa celular para garantir adequada taxa de renovação celular e garantir a reposição das perdas de células da região apical dos vilos (Pluske et al., 1997). Nabuurs (1995) verificou que a redução na altura das vilosidades e o aumento na profundidade das criptas estão relacionados com a mortalidade dos leitões após a desmama. Segundo Cera (1988), a redução na altura das vilosidades representa uma redução da produção de enzimas e da área de absorção, levando a uma taxa de absorção de nutrientes menor. Os nutrientes não absorvidos, além de aumentarem a pressão osmótica na luz intestinal, são utilizados como substrato para os microrganismos patogênicos, predispondo o leitão às diarréias e infecções entéricas.

Os antimicrobianos atuam reduzindo o metabolismo microbiano, o que leva a uma redução da produção de metabólitos (aminas, amônia e endotoxinas), tóxicos ao epitélio intestinal, e da quantidade de microrganismos aderidos aos enterócitos (Lancini, 1994). Apesar da diferença não ser significativa $(\mathrm{P}>0,10)$, os antimicrobianos, em valores numéricos, proporcionaram uma maior altura das vilosidades, em relação ao tratamento controle. Isto poderia ser um reflexo da ação dos antimicrobianos sobre a microbiota. Entretanto, no jejuno e no íleo, este resultado não se repetiu, tornando esta possibilidade pouco provável.

Os efeitos benéficos de probióticos, citados na literatura (Jin et al., 1997; Leedle, 2000b; Menten, 2001) não proporcionaram, como consequência, a melhora na integridade do epitélio intestinal dos leitões deste experimento. Por outro lado, Budiño (2004) verificou que o probiótico à base de Bacillus subtilis e Bacillus licheniformis proporcionou maior altura das vilosidades no duodeno, em relação ao tratamento controle. Além disso, Budiño (2004) verificou que não houve diferença de desempenho dos leitões entre o tratamento controle e o tratamento 
com antibiótico (40 ppm de bacitracina de zinco), o que pode significar que o ambiente experimental, provavelmente, não proporcionou desafio aos leitões.

Analisando os dados em valores numéricos, pode-se notar que, mesmo com diferenças não significativas $(\mathrm{P}>0,10)$, o tratamento prebiótico proporcionou uma maior altura das vilosidades. O prebiótico mananoligossacarídeo é reconhecido por ligar-se às lectinas nas paredes de certas bactérias indesejáveis, dificultando a adesão bacteriana ao epitélio intestinal. Além disso, pode neutralizar micotoxinas, auxiliando na manutenção do epitélio intestinal (Pettigrew, 2000). Tal fato é confirmado por Santos et al. (2002ab) que também observaram, em leitões alimentados com mananoligossacarídeos, aumentos na altura das vilosidades, redução na profundidade das criptas, além de maior relação altura de vilosidade/profundidade de cripta.

Entretanto, o que se pode constatar é que, para os antimicrobianos, probióticos e mananoligossacarídeos, os efeitos significativos $(\mathrm{P}<0,10)$ identificados e as diferenças, em valores numéricos, não foram regulares. Não houve um efeito benéfico e generalizado sobre a histologia epitelial dos segmentos do intestino delgado. Segundo Van Beers-Schreurs et al. (1998), existem fatores mais importantes que a contaminação microbiana e a produção de toxinas pelas bactérias para determinar a atrofia dos vilos e aumento da profundidade das criptas. Estes autores relatam que a desmama (separação das porcas, mudança de ambiente e ingestão de ração) determina, em primeira instância, a redução da altura das vilosidades e o consequente aumento da profundidade das criptas. Assim, possivelmente estes fatores podem ter suprimido um efeito benéfico mais intenso dos antimicrobianos, probióticos e mananoligossacarídeos sobre a histologia epitelial do intestino.

Analisando os dados em valores numéricos, pode-se observar que o tratamento extrato vegetal trouxe efeitos benéficos ao epitélio intestinal, tanto no duodeno quanto no jejuno. Houve aumento, embora não significativo $(\mathrm{P}>0,10)$, da altura das vilosidades e da relação altura de vilosidade/profundidade de cripta. Não foram encontrados dados na literatura a respeito do efeito dos extratos vegetais sobre a histologia intestinal de leitões. Os extratos vegetais devem, possivelmente, estimular um mecanismo de ação semelhante ao que levou ao aumento do peso relativo do pâncreas. Sabe-se que agentes pungentes, como a capsaicina (principal componente do oleoresina da pimenta) aumentam a secreção de saliva e suco gástrico, ativando o sistema nervoso central, por meio de receptores de paladar e olfato. Um efeito semelhante deve ocorrer ao longo do restante do trato digestivo, pois em ratos, os princípios ativos dos extratos vegetais, principalmente a capsaicina, podem aumentar a atividade de enzimas (sacarase e maltase), a secreção exógena pancreática ( $\alpha$-amilase e $\alpha$-lipase) e a secreção de sais biliares (Platel \& 
Srinivasan, 1996). Para que este efeito ocorra, é necessário, também, um aumento do número de células secretoras de enzimas e outras substâncias digestivas. Assim, a maior altura das vilosidades, em valores numéricos $(\mathrm{P}>0,10)$, no duodeno e no jejuno de animais do tratamento extrato vegetal, comparados a animais controle, pode ser consequência de um uma maior taxa de renovação celular nas criptas, provocada por estímulos advindos da ação dos princípios ativos dos extratos vegetais. $\mathrm{O}$ maior valor numérico $(\mathrm{P}>0,10)$ da relação altura de vilosidade/profundidade de cripta, no duodeno e jejuno de leitões deste tratamento, pode ser um outro indicativo do efeito estimulador de proliferação celular causado pelo extrato vegetal. Uma reposição celular adequada proporciona maiores valores na relação altura de vilosidade/profundidade de cripta, indicando presença de maior quantidade de enterócitos maduros e funcionais (Tucci, 2003).

Em relação à área ocupada pelas células caliciformes nos epitélios intestinais, vale destacar que, no duodeno e no jejuno, houve alterações. No duodeno, as alterações não foram significativas $(\mathrm{P}>0,10)$, mas são percebidas ao se observar os valores numéricos. $\mathrm{O}$ epitélio intestinal do duodeno de leitões dos tratamentos probiótico, prebiótico e extrato vegetal apresentou uma menor área ocupada pelas células caliciformes. Este mesmo efeito pôde ser constatado no jejuno $(\mathrm{P}<0,10)$, de forma mais intensa para os tratamentos antimicrobiano e probiótico, e menos intensa para os tratamentos prebiótico e extrato vegetal. A menor área ocupada pelas células caliciformes pode implicar numa menor produção de muco. O muco é uma glicoproteína insolúvel em água, secretada pelas células caliciformes. Estas células aumentam a produção e secreção de muco durante processos infecciosos no intestino delgado. (Macari \& Maiorca, 2000).

A densidade das vilosidades nos segmentos do intestino delgado não foi alterada ( $\mathrm{P}>0,10)$ pelos tratamentos. Budiño (2004) e Tucci (2003) também não constataram alterações nesta variável, alimentando leitões recém-desmamados, respectivamente, com probiótico e mananoligossacarídeo.

\subsubsection{Microbiologia intestinal}


Os resultados obtidos nas análises microbiológicas estão apresentados na Tabela 8. Os microrganismos Staphylococcus spp., Campylobacter coli, Clostridium perfringens e Salmonela spp. não foram analisadas estatisticamente. Apenas uma única amostra foi positiva para Staphylococcus (animal 4 do tratamento extrato vegetal) e Campylobacter coli (animal 3 do tratamento prebiótico) e quatro amostras para Clostridium perfringens (um animal de cada tratamento, exceto o tratamento probiótico). Já os microrganismos Salmonela spp. não foram identificados em nenhuma das amostras. Nenhum dos tratamentos foi eficaz em definir um perfil específico da microbiota para as variáveis estudadas (microrganismos totais, gram positivas totais, gram negativas totais, Bacillus spp., Escherichia coli, Streptococcus spp., Staphylococcus spp., Campylobacter coli, Clostridium perfringens).

As análises prévias de microbiologia foram feitas em animais sadios e com diarréia, nascidos e desmamados no próprio Setor de Suinocultura do Departamento de Zootecnia da ESALQ/USP. Os animais ocupavam a creche experimental durante os 14 dias pósdesmama e apresentavam Salmonella, Streptococcus, Staphylococcus, E.coli, Campylobacter coli e Clostridium perfringens como componentes da microbiota. Assim, ficou constatado o desafio proporcionado por microrganismos presentes no ambiente experimental. Entretanto, poucos animais apresentaram contaminação por estes microrganismos, o que impediu a identificação do perfil de ação dos promotores do crescimento sobre parte da microbiota. Algumas prováveis explicações podem ser sugeridas: procedência e estado sanitário e nutricional dos animais experimentais, melhor qualidade das dietas experimentais, problemas na coleta e no transporte das amostras, ou ainda, ação efetiva dos promotores do crescimento.

Os animais do Experimento I foram adquiridos da Granja Água Branca, localizada no município de Itu/SP, a $80 \mathrm{~km}$ de Piracicaba/SP. Nesta granja os leitões recebem uma alimentação complexa, livre de promotores do crescimento, a partir do sétimo dia de vida. Os leitões são desmamados aos 21 dias de idade com peso vivo em torno de $6 \mathrm{~kg}$. Para o Experimento I, um grupo de 45 leitões (peso vivo de 5,8 kg em média aos 21 dias de idade) foi desmamado e imediatamente transportado para as instalações experimentais, na ESALQ/USP, em Piracicaba/SP. Todo o grupo apresentava excelentes condições sanitárias e corporais. Eram animais mais pesados e sadios, comparados aos animais nos quais foram realizadas as análises prévias de contaminação microbiológica. Talvez esta diferença na saúde e no estado geral dos leitões possa ser uma das causas para a ausência de efeitos sobre a microbiota. 
Tabela 8. Médias de microrganismos totais, gram positivos totais, gram negativos totais, Bacillus spp. e Escherichia coli no conteúdo do jejuno/íleo, em função dos tratamentos (Experimento I)

\begin{tabular}{|c|c|c|c|c|c|c|}
\hline \multirow[b]{2}{*}{ Tratamento } & \multicolumn{6}{|c|}{ Log UFC/g (unidades formadoras de colônia por grama de amostra) } \\
\hline & 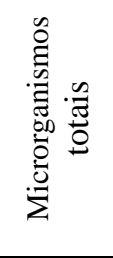 & 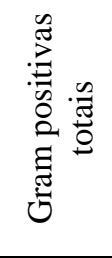 & 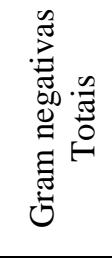 & 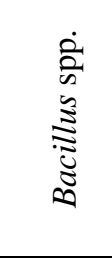 & 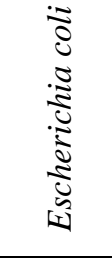 & 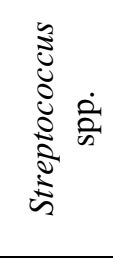 \\
\hline Controle & 5,511 & 5,416 & 4,994 & 3,861 & 4,383 & 3,794 \\
\hline Antimicrobiano & 5,857 & 5,659 & 5,033 & 4,838 & 3,969 & 3,000 \\
\hline Probiótico & 6,245 & 6,184 & 4,865 & 4,966 & 4,032 & 4,364 \\
\hline Prebiótico & 5,759 & 5,503 & 4,729 & 3,000 & 3,610 & 5,090 \\
\hline Extrato vegetal & 5,957 & 5,766 & 4,810 & 4,882 & 3,622 & 4,442 \\
\hline Média & 5,866 & 5,705 & 4,886 & 4,309 & 3,923 & 4,138 \\
\hline $\operatorname{Pr}>F$ & 0,8671 & 0,8539 & 0,9808 & 0,1621 & 0,9185 & 0,4319 \\
\hline $\mathrm{CV}^{1}(\%)$ & 16,534 & 18,34 & 16,50 & 28,35 & 34,50 & 37,40 \\
\hline
\end{tabular}

${ }^{1}$ Coeficiente de variação

As dietas experimentais são muito diferentes das dietas normalmente fornecidas aos animais do Setor de Suinocultura da ESALQ/USP. Estas são produzidas à base de milho e farelo de soja, contendo apenas óxido de zinco como preventivo de diarréias. Já as dietas experimentais foram confeccionadas com milho, farelo de soja, plasma sanguíneo "spray dried”, lactose, soro de leite em pó e aminoácidos sintéticos. Não foi adicionado nenhum promotor do crescimento nas dietas do tratamento controle. No entanto, as dietas continham $4 \%$ e $2 \%$ de plasma sanguíneo "spray dried” nas fases pré-inicial e inicial, respectivamente. Este ingrediente possui imunoglobulinas que auxiliam o leitão recém-desmamado a manter o equilíbrio da microbiota, resultando em melhoras no desempenho e no estado de saúde (Kats et al., 1994; Gatnau et al., 1995; Cain \& Zimmerman, 1997). Assim, o plasma "spray dried”, aliado à qualidade de ingredientes lácteos, pode ter sido responsável por parte do controle da microbiota patogênica.

Pode-se sugerir, também, que os promotores do crescimento testados foram efetivos em controlar a contaminação pelos microrganismos analisados, uma vez que, apesar de não haver diferença estatística significativa, notou-se uma maior contaminação de E. coli no 
tratamento controle. Além disso, houve uma maior contaminação por Streptococcus spp. nos tratamentos probiótico, prebiótico e extrato vegetal.

Além da questão da procedência dos animais, da qualidade das dietas e da eficiência dos promotores no combate aos patógenos, deve-se considerar que problemas podem ter ocorrido durante a coleta e transporte das amostras, como por exemplo, a baixa sobrevivência das bactérias desde momento da coleta até a semeadura nos meios de cultivos. Segundo Apajalahti \& Bedford (1999), a coleta e o transporte das amostras são os pontos mais crítico na análise microbiológica em meios de cultura, pois, uma exposição ao ar, mesmo que em períodos mínimos até o momento da semeadura, pode levar a uma alteração drástica no perfil e na quantidade de microrganismos. Por este motivo, as técnicas de cultivo em meios de cultura são limitadas, podendo produzir dados muito pouco precisos ou equivocados (Apajalahti \& Bedford, 1999; Simpson et al., 1999). Segundo Apajalahti \& Bedford (1999), as técnicas moleculares de identificação e quantificação microbiana, que estão sendo desenvolvidas, são muito mais adequadas.

Um outro argumento, que pode acusar problemas nas análises microbiológicas, está ligado à ausência de efeito dos antimicrobianos sobre o perfil de microrganismos analisados. Quando há desafio, há melhora no desempenho dos animais alimentados com promotores do crescimento antimicrobianos. Este efeito está relacionado à ação dos antimicrobianos sobre a microbiota intestinal, pois, já foi demonstrado que animais "germ-free” não são beneficiados (Menten, 1995). No entanto, não foi observado nenhum efeito do tratamento antimicrobiano sobre a microbiota.

Portanto, os possíveis problemas no processo de coleta, transporte e análise das amostras podem ter influenciado as análises microbiológicas, que, por sua vez, demonstram não haver efeito dos promotores do crescimento sobre a microbiota. 


\section{4 .1.4 Digestibilidade dos nutrientes}

A Tabela 9 mostra as médias dos coeficientes de digestibilidade aparente da matéria seca, energia bruta e proteína bruta, em função dos tratamentos. Já a Tabela A1 (Apêndice) mostra os resultados das análises bromatológicas (matéria seca, energia bruta e proteína bruta) e das análises de cromo em base de matéria seca, para as amostras de fezes e dietas experimentais iniciais.

Tabela 9. Médias dos coeficientes de digestibilidade aparente para matéria seca, energia bruta e proteína bruta, em função dos tratamentos

\begin{tabular}{|c|c|c|c|}
\hline \multirow[b]{2}{*}{ Tratamentos } & \multicolumn{3}{|c|}{ Coeficientes de digestibilidade aparente (\%) } \\
\hline & Matéria seca ${ }^{1}$ & Energia bruta $^{1}$ & Proteína bruta $^{1}$ \\
\hline Controle & $73,20 \pm 1,99$ c & $72,58 \pm 2,66$ bc & $71,03 \pm 1,89 \mathrm{~b}$ \\
\hline Antimicrobiano & $80,61 \pm 1,55$ a & $80,51 \pm 1,27 \mathrm{a}$ & $78,57 \pm 3,50$ a \\
\hline Probiótico & $73,16 \pm 1,85$ c & $68,55 \pm 2,39$ c & $68,34 \pm 2,97 \mathrm{~b}$ \\
\hline Prebiótico & $75,70 \pm 1,58$ bc & $69,75 \pm 0,92$ bc & $67,73 \pm 2,43 \mathrm{~b}$ \\
\hline Extrato vegetal & $79,27 \pm 2,34 \mathrm{ab}$ & $74,64 \pm 3,19 \mathrm{~b}$ & $74,23 \pm 4,02 \mathrm{ab}$ \\
\hline Média & $76,39 \pm 3,57$ & $73,21 \pm 4,78$ & $71,98 \pm 4,94$ \\
\hline $\operatorname{Pr}>F$ & 0,0004 & $<0,0001$ & 0,0033 \\
\hline $\mathrm{CV}^{2}(\%)$ & 2,61 & 3,20 & 4,64 \\
\hline
\end{tabular}

${ }^{1}$ Letras diferentes, na coluna, diferem significativamente pelo teste de Tukey $(\mathrm{P}<0,05)$.

${ }^{2}$ Coeficiente de variação.

O tratamento com antimicrobianos promoveu um aumento $(\mathrm{P}<0,05)$ nos coeficientes de digestibilidade aparente de matéria seca (CDapMS), proteína bruta (CDapPB) e energia bruta (CDapEB) em relação ao tratamento controle. Todavia, o CDapMS e o CDapPB do tratamento antimicrobiano foram similares $(\mathrm{P}>0,05)$ àqueles do tratamento com extrato vegetal. Apenas o CDapEB do tratamento antimicrobiano foi significativamente superior $(\mathrm{P}<0,05)$ a todos os outros tratamentos.

O tratamento extrato vegetal, por sua vez, diferiu $(\mathrm{P}<0,05)$ do tratamento controle apenas no CDapMS e do tratamento probiótico (PO) para o CDapEB. Já os tratamentos prebiótico e probiótico não alteraram $(\mathrm{P}>0,05)$ a digestibilidade aparente em relação ao tratamento controle.

Parte da melhora da digestibilidade da energia, proporcionada pelo tratamento antimicrobiano, pode ter sido causada pela menor utilização da energia da dieta pela microbiota. Os microrganismos do intestino delgado e estômago competem pelos nutrientes com o 
hospedeiro e, em suínos, até 6\% da energia bruta da dieta pode ser perdida devido à fermentação microbiana (Jensen, 1998). Os antimicrobianos podem reduzir a população microbiana, diminuindo a fermentação de carboidratos e aumentar a disponibilidade para absorção (Anderson et al., 1999). Entretanto, as análises microbiológicas não acusaram a redução da contagem de microrganismos totais no jejuno/íleo dos leitões do tratamento antimicrobiano. De qualquer maneira, os antimicrobianos podem ter alterado a microbiota, pois também houve melhora nos coeficientes de digestibilidade aparente matéria seca, energia e proteína bruta. A alteração e/ou redução da microbiota pelos antimicrobianos além de disponibilizar mais carboidratos e aminoácidos para absorção, ainda reduz a adesão de bactérias e a produção de toxinas pelas mesmas, melhorando a integridade do epitélio intestinal (Butolo, 1999; Baynes \& Varley, 2001).

Os tratamentos probiótico e prebiótico não melhoraram $(\mathrm{P}>0,05)$ a digestibilidade aparente dos nutrientes estudados. Na verdade, houve uma ligeira queda nos coeficientes de digestibilidade aparente da energia bruta e proteína bruta, em relação ao tratamento controle. No entanto, essas diferenças não foram significativas $(\mathrm{P}>0,05)$.

Os Bacillus subtilis e os Bacillus licheniformis possuem atividade secretora de enzimas proteolíticas, aminolíticas e lipolíticas, auxiliando o hospedeiro a digerir certos tipos de substratos (Jensen \& Jensen, 1992). Vassalo (1995) demonstrou que, devido a este tipo de atividade, Bacillus toyoi podem melhorar a digestibilidade da energia, porém em condições de desafio muito baixo. Talvez, as condições de desafio, nas quais foi realizado o Experimento I, possam prejudicar ou anular as funções probióticas dos Bacillus, inclusive a função secretora de enzimas.

Ferket (2003) observou que a ação dos prebióticos sobre a microbiota e sobre a resposta do sistema imune pode trazer benefícios à estrutura do epitélio intestinal e melhorar a digestibilidade dos nutrientes. No entanto, pôde-se constatar no Experimento I que o mananoligossacarídeo proporcionou apenas melhoras discretas à estrutura do epitélio intestinal do duodeno e não melhorou a digestibilidade dos nutrientes.

Apesar de não haver diferença significativa $(\mathrm{P}>0,05)$, o tratamento extrato vegetal mostrou, em valores numéricos, que pode incrementar a digestibilidade de nutrientes. $\mathrm{O}$ efeito é menos intenso do que o causado pelo uso de antimicrobianos, mas pode ser notado ao se comparar com o tratamento controle. Os extratos vegetais aumentaram o peso relativo do pâncreas, o que pode ser um indicativo de uma maior secreção de enzimas. Na década de 80, não se aceitava que o aumento da secreção exócrina pancreática pudesse melhorar o desempenho e a 
digestibilidade, pois, leitões acima de 49 dias de idade seriam capazes de secretar 10 a 100 vezes mais enzimas pancreáticas do que o necessário (Zebrowska et al., 1983; Corring et al., 1989). No entanto, trabalhos mais recentes (Botermans \& Pierzynowisk, 1999; Botermans et al., 2001) vêm demonstrando que o aumento da secreção exócrina pode influenciar na digestibilidade e no desempenho de leitões, pois, além da função digestiva direta, a secreção exócrina pancreática tem um papel muito importante na regulação de metabólitos produzidos pela mucosa intestinal e relacionados à absorção de aminoácidos e peptídeos. Além disso, a capsaicina (principal princípio ativo da pimenta) pode aumentar a secreção de saliva e de suco gástrico, ativando o sistema nervoso pelo olfato e/ou paladar (Sreenivasamurthy \& Krishnamurthy, 1959). Platel \& Srinivasan (1996) verificaram que, em ratos, o principal princípio ativo do extrato vegetal de pimenta, a capsaicina, pode aumentar a atividade de enzimas produzidas na mucosa intestinal (sacarase e maltase) e no pâncreas ( $\alpha$-amilase e $\alpha$-lipase), melhorando a digestibilidade de carboidratos e gorduras. Além disso, pelos valores numéricos $(\mathrm{P}>0,10)$ das análises histológicas, pode-se observar que os extratos vegetais promoveram uma maior altura de vilosidade e uma maior relação altura de vilosidade/profundidade de cripta. Este fato pode ser um indicativo de que as vilosidades do epitélio intestinal dos leitões do tratamento extrato vegetal sejam constituídas de enterócitos mais maduros e funcionais (Tucci, 2003), havendo maior secreção de enzimas e melhor absorção de nutrientes. Portanto, o tratamento extrato vegetal pode ter aumentado a secreção pancreática exócrina e a atividade de enzimas e melhorado condição histológica do epitélio intestinal, melhorando a digestibilidade.

\subsection{Experimento II}

\subsubsection{Desempenho}

As médias das variáveis de desempenho são apresentadas nas Tabelas 10, 11 e 12, respectivamente, para os períodos de um a 14, 15 a 35 e um a 35 dias de experimentação. As Tabelas A6, A7, A8 e A9 (Apêndice) apresentam os dados por unidade experimental, referentes ao peso vivo, consumo diário de ração, ganho diário de peso e conversão alimentar, respectivamente. Já as Tabelas A13, A14 e A15 (Apêndice) apresentam as temperaturas diárias máximas e mínimas para as repetições 1,2 e 3. 
Aos 14 dias de experimentação, o peso vivo (PV 14) dos animais do tratamento prebiótico foi superior $(\mathrm{P}<0,05)$ ao dos animais do tratamento extrato vegetal. Pela observação dos dados, houve uma tendência numérica $(\mathrm{P}>0,10)$ de o tratamento prebiótico proporcionar maior PV 14, comparado aos tratamentos controle, antimicrobiano e probiótico. A mesma resposta foi observada para o ganho diário de peso no período de um a 14 dias de experimentação (GDP 1-14).

Tabela 10. Médias de peso vivo (PV 14) aos 14 dias de experimentação e consumo diário de ração (CDR 1-14), ganho diário de peso (GDP 1-14) e conversão alimentar (CA 1-14) para o período de um a 14 dias de experimentação

\begin{tabular}{lcccc}
\hline & \multicolumn{4}{c}{ Variáveis } \\
\cline { 2 - 5 } Tratamento & $\begin{array}{c}\text { PV 14 } \\
(\mathrm{kg})\end{array}$ & $\begin{array}{c}\text { CDR 1-14 } \\
(\mathrm{kg} / \mathrm{dia})\end{array}$ & $\begin{array}{c}\text { GDP 1-14 } \\
(\mathrm{kg} / \mathrm{dia})\end{array}$ & CA 1-14 \\
\hline Controle & $8,32 \pm 0,88 \mathrm{ab}$ & $0,278 \pm 0,04 \mathrm{ab}$ & $0,163 \pm 0,04 \mathrm{ab}$ & $1,79 \pm 0,48$ \\
Antimicrobiano & $8,77 \pm 1,14 \mathrm{ab}$ & $0,305 \pm 0,06 \mathrm{a}$ & $0,195 \pm 0,08 \mathrm{ab}$ & $1,72 \pm 0,49$ \\
Probiótico & $8,04 \pm 0,72 \mathrm{ab}$ & $0,260 \pm 0,06 \mathrm{ab}$ & $0,142 \pm 0,06 \mathrm{ab}$ & $2,06 \pm 0,75$ \\
Prebiótico & $8,91 \pm 1,08 \mathrm{a}$ & $0,305 \pm 0,05 \mathrm{a}$ & $0,205 \pm 0,05 \mathrm{a}$ & $1,55 \pm 0,29$ \\
Extrato vegetal & $7,88 \pm 0,98 \mathrm{~b}$ & $0,252 \pm 0,04 \mathrm{~b}$ & $0,131 \pm 0,06 \mathrm{~b}$ & $1,93 \pm 0,47$ \\
\multicolumn{1}{c}{ Média } & $8,38 \pm 1,02$ & $0,280 \pm 0,05$ & $0,167 \pm 0,06$ & $1,81 \pm 0,53$ \\
$\operatorname{Pr}>\mathrm{F}$ & 0,0193 & 0,0330 & 0,0188 & 0,2069 \\
$\mathrm{CV}^{3}(\%)$ & 10,21 & 17,97 & 36,75 & 29,98 \\
\hline
\end{tabular}

${ }^{1}$ Letras diferentes, na coluna, diferem significativamente pelo teste de Tukey $(\mathrm{P}<0,05)$.

${ }^{2}$ Letras diferentes, na coluna, diferem significativamente pelo teste de Tukey $(\mathrm{P}<0,10)$.

${ }^{3}$ Coeficiente de variação.

Tabela 11. Médias de peso vivo (PV 35) aos 35 dias de experimentação e consumo diário de ração (CDR 15-35), ganho diário de peso (GDP15-35) e conversão alimentar (CA 1535) para o período de 15 a 35 dias de experimentação

\begin{tabular}{|c|c|c|c|c|}
\hline \multirow[b]{2}{*}{ Tratamento } & \multicolumn{4}{|c|}{ Variáveis } \\
\hline & $\begin{array}{c}\text { PV } 35^{1} \\
(\mathrm{~kg})\end{array}$ & $\begin{array}{c}\text { CDR 15-35 } \\
\text { (kg/dia) }\end{array}$ & $\begin{array}{c}\text { GDP } 15-35^{1} \\
(\mathrm{~kg} / \mathrm{dia})\end{array}$ & CA $15-35$ \\
\hline Controle & $19,09 \pm 2,37 \mathrm{~b}$ & $0,817 \pm 0,16 \mathrm{ab}$ & $0,512 \pm 0,08 \mathrm{~b}$ & $1,59 \pm 0,15$ \\
\hline Antimicrobiano & $21,92 \pm 2,55 \mathrm{a}$ & $0,952 \pm 0,15$ a & $0,625 \pm 0,07$ a & $1,51 \pm 0,09$ \\
\hline Probiótico & $18,50 \pm 2,71 \mathrm{~b}$ & $0,741 \pm 0,16 \mathrm{~b}$ & $0,498 \pm 0,10 \mathrm{~b}$ & $1,55 \pm 0,16$ \\
\hline Prebiótico & $20,84 \pm 2,97 \mathrm{ab}$ & $0,883 \pm 0,16 \mathrm{ab}$ & $0,568 \pm 0,10 \mathrm{ab}$ & $1,55 \pm 0,12$ \\
\hline Extrato vegetal & $18,47 \pm 2,53 \mathrm{~b}$ & $0,747 \pm 0,13 b$ & $0,503 \pm 0,08 \mathrm{~b}$ & $1,48 \pm 0,08$ \\
\hline Média & $19,76 \pm 2,90$ & $0,828 \pm 0,17$ & $0,541 \pm 0,10$ & $1,53 \pm 0,13$ \\
\hline $\operatorname{Pr}>F$ & 0,0009 & 0,0004 & 0,0007 & 0,2336 \\
\hline $\mathrm{CV}^{2}(\%)$ & 11,34 & 14,99 & 14,47 & 7,70 \\
\hline
\end{tabular}

${ }^{1}$ Letras diferentes, na coluna, diferem significativamente pelo teste de Tukey $(\mathrm{P}<0,05)$.

${ }^{2}$ Coeficiente de variação. 
Tabela 12. Médias de consumo diário de ração (CDR 1-35), ganho diário de peso (GDP 1-35) e conversão alimentar (CA 1-35) para o período de um a 35 dias de experimentação

\begin{tabular}{lccc}
\hline Tratamento & $\begin{array}{c}\text { CDR 1-35 } \\
(\mathrm{kg} / \mathrm{dia})\end{array}$ & $\begin{array}{c}\text { Variáveis } \\
\text { GDP 1-35 } \\
(\mathrm{kg} / \mathrm{dia})\end{array}$ & CA 1-35 \\
\hline Controle & $0,602 \pm 0,11 \mathrm{abc}$ & $0,373 \pm 0,06 \mathrm{~b}$ & $1,61 \pm 0,12$ \\
Antimicrobiano & $0,693 \pm 0,10 \mathrm{a}$ & $0,453 \pm 0,06 \mathrm{a}$ & $1,53 \pm 0,11$ \\
Probiótico & $0,549 \pm 0,11 \mathrm{c}$ & $0,356 \pm 0,08 \mathrm{~b}$ & $1,59 \pm 0,09$ \\
Prebiótico & $0,652 \pm 0,11 \mathrm{ab}$ & $0,423 \pm 0,07 \mathrm{ab}$ & $1,54 \pm 0,09$ \\
Extrato vegetal & $0,549 \pm 0,09 \mathrm{bc}$ & $0,354 \pm 0,07 \mathrm{~b}$ & $1,56 \pm 0,12$ \\
\multicolumn{1}{c}{ Média } & $0,609 \pm 0,12$ & $0,392 \pm 0,08$ & $1,57 \pm 0,11$ \\
\multicolumn{1}{c}{ Pr $>$ F } & 0,0005 & 0,0009 & 0,2947 \\
\hline
\end{tabular}

${ }^{1}$ Letras diferentes, na coluna, diferem significativamente pelo teste de Tukey $(\mathrm{P}<0,05)$.

${ }^{2}$ Coeficiente de variação.

Nos primeiros 14 dias de experimentação, também, houve maior $(\mathrm{P}<0,10)$ consumo diário de ração (CDR 1-14) para os tratamentos antimicrobiano e prebiótico, em relação ao tratamento extrato vegetal. Já os tratamentos controle e probiótico não diferiram estatisticamente $(\mathrm{P}<0,10)$ de nenhum dos outros tratamentos, mas apresentaram CDR 1-14 intermediário. A conversão alimentar (CA 1-14) no período de um a 14 dias de experimentação não foi afetada $(\mathrm{P}>0,10)$ pelos tratamentos.

No período de 15 a 35 dias de experimentação (Experimento II), o consumo diário de ração (CDR 15-35) foi superior para o tratamento antimicrobiano $(\mathrm{P}<0,05)$ em relação aos tratamentos probiótico e extrato vegetal. Já os tratamentos prebiótico e controle não diferiram $(\mathrm{P}>0,05)$ de nenhum outro tratamento para o CDR 15-35. O peso vivo aos 35 dias de experimentação (PV 35) e ganho diário de peso no período de 15 a 35 dias de experimentação (GDP 15-35) do tratamento antimicrobiano foram superiores $(\mathrm{P}<0,05)$ aos tratamentos controle, probiótico e extrato vegetal, os quais não diferiram $(\mathrm{P}>0,05)$ entre si. $\mathrm{O}$ tratamento prebiótico não diferiu estatisticamente $(\mathrm{P}>0,05)$ de nenhum outro tratamento, apresentando valores de $\mathrm{PV}$ 35 e GDP 15-35 intermediários. A conversão alimentar (CA 15-35), no período de 15 a 35 dias de experimentação, não foi afetada pelos tratamentos ( $\mathrm{P}>0,05)$.

No período de um a 35 dias de experimentação, o consumo diário de ração (CDR 1-35) dos animais do tratamento antimicrobiano foi superior $(\mathrm{P}<0,05)$ aos dos tratamentos extrato vegetal e probiótico. O CDR 1-35 no tratamento prebiótico não diferiu estatisticamente 
$(\mathrm{P}>0,05)$ dos tratamentos controle e antimicrobiano. Já a conversão alimentar (CA 1-35), no período de um a 35 dias de experimentação, não foi afetada pelos tratamentos ( $\mathrm{P}>0,05)$.

O CDR dos leitões do tratamento antimicrobiano foi superior ao daqueles do tratamento controle, proporcionando um resultado superior no GDP, principalmente para o período de 1-35 dias de experimentação. Na verdade, os antimicrobianos melhoraram o ganho diário de peso (GDP 1-35) em 21,4\%, comparado ao tratamento controle. O aumento no GDP foi superior a média encontrada na literatura, que é de 16,4\%, segundo Hays (1979) e Zimmerman (1986), citados por Cromwell (1991), e de 11\%, calculada por Menten (1995), a partir de uma compilação de dados de experimentos realizados no Brasil. Este resultado é uma indicação de uma situação de elevado desafio aos leitões durante o período experimental, pois, quanto maior o desafio, maior o efeito dos antimicrobianos (Bellaver, 2000; Menten, 2001). Em condições experimentais, onde o ambiente é melhor controlado e higienizado (menor desafio), normalmente os efeitos benéficos dos agentes antimicrobianos no desempenho dos leitões são menores, do que em condições normais de campo (Menten, 2001). Trabalhos clássicos, citados por Menten (2001), demonstraram que animais “germ-free” não se beneficiam do efeito promotor do crescimento, pois a ação dos antimicrobianos seria sobre a microbiota. Apesar das análises microbiológicas não identificarem nenhuma alteração no perfil da microbiota de animais do tratamento antimicrobiano, é possível que tenha havido desafio microbiológico e que os antimicrobianos podem ter agido sobre a microbiota, melhorando o desempenho dos leitões.

Ao contrário do tratamento antimicrobiano, o CDR dos animais do tratamento extrato vegetal, para todos os períodos, foi relativamente baixo, sendo inclusive, numericamente, inferior ao tratamento controle. Os extratos vegetais adicionados às dietas possuíam diversos fatores pungentes que podem ter causado este efeito, pois o material encapsulante libera o conteúdo ao entrar em contato com a saliva. Assim, possivelmente, esta seja uma das causas do baixo GDP em todos os períodos.

Uma situação semelhante ocorreu com o CDR dos leitões do tratamento probiótico, proporcionando um GDP inferior em todos os períodos. A causa do baixo consumo não deve estar ligada à palatabilidade.

O resultado de desempenho para o tratamento probiótico não concorda com algumas referências encontradas na literatura científica. Apesar dos resultados das pesquisas com probióticos serem muito variáveis (Bellaver, 2000), Stewart \& Chesson (1993) reuniram trabalhos na literatura, utilizando diversos tipos de probióticos, e concluíram que, em média, há um aumento de 4,8\% no GDP de leitões na fase inicial. Roth \& Kirchgessener (1988), utilizando 
probiótico à base de Bacillus também conseguiram resultados positivos no GDP de leitões recém-desmamados.

A probabilidade dos esporos de Bacillus subtilis e Bacillus licheniformis não serem viáveis no momento da ingestão da ração pelos animais é muito pequena, pois são formas muito resistentes. Segundo Nicholson et al. (2001), os esporos de Bacillus spp. são resistentes ao calor e umidade, ao calor seco, à radiação ultra-violeta, à radiação gama, agentes oxidantes e pressão. Como o probiótico sempre foi utilizado num período inferior a 30 dias de sua fabricação e não houve nenhum tipo de processamento da ração (peletização, extrusão, etc.), não há motivos para suspeitar que havia uma baixa viabilidade do probiótico no momento da ingestão, levando ao baixo desempenho.

Considerando o probiótico ativo e funcional, vale lembrar que os Bacillus spp. não fazem parte da microbiota natural do suíno e não se fixam ao epitélio intestinal (Huyghebaert, 2003), o que pode prejudicar a sua atuação, direta e indireta, contra os microrganismos patógenos. Entretanto, Murata et al. (1996) provaram que, no intestino de pintos, o Bacillus subtilis aumenta o consumo de oxigênio e beneficiam o crescimento de bactérias benéficas, como os Lactobacillus, os quais produzem ácido lático e, como consequência, controlam patógenos (E. coli, Salmonella, Clostridium e Campylobacter). Como o desempenho dos animais não foi melhorado, pode-se sugerir que o probiótico utilizado (Bacillus subtilis e Bacillus licheniformis), possivelmente não tenha sido adequado à situação de desafio microbiano do Experimento II. Vassalo (1995) demonstrou que o uso de probióticos à base de Bacillus toyoi melhorou o GDP de leitões recém-desmamados, porém não havia desafio microbiológico nas instalações, já que não houve diferença entre o tratamento controle e antimicrobiano (bacitracina de zinco, 30 ppm). Kreuzer (1994) e Budiño (2004), fornecendo Bacillus subtilis e Bacillus licheniformis a leitões recém-desmamados encontraram resultados semelhantes a Vassalo (1995), porém, utilizando carbadox (50 ppm) e bacitracina de zinco (40ppm), respectivamente, como antimicrobiano. Portanto, talvez, em situações de nenhum, ou baixo desafio, os probióticos à base de Bacillus spp. podem proporcionar melhoras no desempenho de leitões. Contudo, em situações de alto desafio, o efeito deste probiótico pode ser nulo e até negativo. Na realidade, as técnicas de plaqueamento, até hoje utilizadas, limitam muito o estudo da flora microbiana, que é extremamente complexo (Leedle, 2000b). A partir do uso das técnicas moleculares, será possível aumentar sensivelmente o conhecimento sobre o ecossistema intestinal, adequando o uso dos probióticos para situações específicas de estresse, desequilíbrio e desafio (Leedle, 2000b). 
O desafio microbiano para o probiótico utilizado é muito importante. Entretanto, não se descarta o fato de que alguns microrganismos probióticos, quando em excesso na luz intestinal, podem causar efeitos colaterais e prejudicar o hospedeiro. Em humanos, já foi constatado que componentes da parede celular (peptideoglicanas) de bactérias gram positivas, como os Bacillus spp., podem causar efeitos colaterais como febre, artrite, cardioangites, lesões hepatobiliares e doenças auto-imunes (Schwabb, 1993). Além disso, os microrganismos probióticos em excesso também podem induzir diarréias e causar lesões intestinais, principalmente através da desconjugação e desidroxilação de sais biliares (Donohue \& Salminen, 1996). Assim, mesmo utilizando a dosagem do probiótico sugerida pelo fabricante, pode ser possível que o excesso do Bacillus subtilis e Bacillus licheniformis tenha afetado o desempenho dos animais.

O tratamento prebiótico mananoligossacarídeo, em termos de GDP e CDR, foi bastante eficiente, principalmente nos primeiros 14 dias de experimentação. O CDR 1-14 e o GDP 1-14 foram iguais $(\mathrm{P}>0,10)$ ao tratamento antimicrobiano que, por sua vez, foi 9,7\% superior ao controle no CDR 1-14 e 19,6\% no GDP 1-14. Numericamente, o GDP 1-14 do tratamento prebiótico foi, inclusive, 5,1\% superior ao tratamento antimicrobiano. Entretanto, os tratamentos prebiótico e antimicrobiano não foram estatisticamente superiores ao controle ( $\mathrm{P}>0,10)$. Nos demais períodos (15-35 e 1-35 dias de experimentação), o mananoligossacarídeo proporcionou um desempenho intermediário entre os tratamentos controle e antimicrobiano. Enquanto o tratamento antibiótico foi superior $(\mathrm{P}>0,05)$ ao tratamento controle nestes períodos, o tratamento prebiótico não diferiu estatisticamente de nenhum dos dois ( $\mathrm{P}>0,05)$. Entretanto, o maior GDP foi consequência de um maior CDR, uma vez que a CA não foi afetada pelo prebiótico mananoligossacarídeo. Spring (2000), relatou alguns trabalhos científicos, nos quais o uso de mananoligossacarídeo nas dietas de leitões recém-desmamados melhorou $(\mathrm{P}<0,05)$ o GDP e o CDR, mas não alterou a CA $(\mathrm{P}>0,05)$.

Este adequado desempenho dos animais pode estar ligado à ação do mananoligossacarídeo sobre a microbiota, a histologia e a resposta imune. No entanto, não há evidências de que a microbiota foi alterada beneficamente e os resultados das análises histológicas não acusaram nenhum efeito claro. Assim, há possibilidade de que o efeito do mananoligossacarídeo possa ter sido sobre o sistema imune dos animais. O mananoligossacarídeo tem demonstrado ser um eficiente agente promotor da imunidade humoral contra microrganismos patógenos específicos, evitando a colonização, permitindo a sua apresentação às células do sistema imune (Ferket, 2003) e aumentando a presença de IgG no 
sangue e IgA na bile e na mucosa intestinal (Savage et al., 1996). Este mecanismo é possível, pois, as estruturas moleculares das bactérias invasoras, como lipopolissacarídeos e peptideoglicanos e, possivelmente, as estruturas de manose das paredes celulares de leveduras são reconhecidas pelo sistema imunológico (Newman, 1994). Ativando a resposta humoral, haverá economia de energia, pois a resposta inflamatória ativa despenderia um esforço energético muito maior (Humprey et al., 2002, citados por Ferket, 2003). A resposta imunológica ativa provoca febre (que diminui o apetite), impede a concentração de reservas corporais (glicose, aminoácidos e minerais) no fígado, músculos e ossos, suprime a absorção de nutrientes nos intestinos e aumenta a perda de fluídos corporais na forma de diurese e diarréia (Ferket, 2003). A ativação crônica da resposta imunológica ativa, portanto, é prejudicial ao desempenho do animal (Ferket, 2002). Assim, apesar de não se ter realizada nenhuma análise comprobatória, o mananoligossacarídeo pode ter agido sobre o sistema imune, proporcionando boas condições para que o animal expressasse seu potencial genético. Deve ser lembrado, também, que a resposta do desempenho dos leitões foi expressa em termos de CDR e GDP, não havendo alterações sobre a digestibilidade e CA.

Pode-se observar que há uma grande diferença numérica nos valores da CA 1-14 entre os tratamentos prebiótico e probiótico, embora não significativa $(\mathrm{P}>0,10)$. $\mathrm{O}$ alto coeficiente de variação (29,98\%) da CA 1-14 foi, possivelmente, o responsável pela não detecção da diferença significativa. Nos outros dois períodos (15-35 e 1-35 dias), o coeficiente de variação para a CA foi bem inferior (7-8\%). Mesmo assim, não houve diferença entre os tratamentos $(\mathrm{P}>0,05)$. Numericamente, a CA 1-35 do tratamento antimicrobiano foi melhor do que o tratamento controle em 4,9\%. Em média, os antimicrobianos podem melhorar a CA em 6,9\% na fase de creche (Hays, 1979; Zimmerman, 1986; citados por Cromwell, 1991).

Os melhores índices de CA podem ser resultados de uma melhor absorção dos nutrientes aliada ao menor gasto de energia e proteína para a manutenção do trato gastrintestinal. A digestibilidade aparente da matéria seca, energia bruta e proteína bruta dos animais do tratamento antimicrobiano foi superior. Além disso, houve redução, em números absolutos ( $\mathrm{P}>0,10)$, nos pesos relativos vazios dos intestinos delgado e grosso (ceco e colo) vazios, no trato gastrintestinal total e no comprimento relativo do intestino delgado.

Um comportamento similar foi observado para a CA dos leitões submetidos ao tratamento extrato vegetal no período de 15-35 dias de experimentação. A CA 15-35 não diferiu estatisticamente $(\mathrm{P}>0,05)$, apesar de melhorar 6,9\%, em relação ao tratamento controle. Considerando que a CA alimentar foi melhorada, o aumento da digestibilidade talvez seja a 
melhor explicação. Houve uma melhora significativa $(\mathrm{P}<0,05)$ na digestibilidade da matéria seca da dieta $(8,3 \%)$ e não significativa $(\mathrm{P}>0,05)$ na digestibilidade da energia bruta $(2,8 \%)$ e da proteína bruta (4,5\%). Como discutido anteriormente, talvez os extratos vegetais podem ter causado um estímulo da atividade de enzimas (amilase, sacarase e lipase) e na secreção de saliva, suco gástrico, suco pancreático e sais biliares (Ganesh Baht et al., 1984; Sambaiah \& Srinivasan, 1991; Platel \& Srinivasan, 1996; Wang \& Bourne, 1998). Outra justificativa para as melhoras na digestibilidade e na CA pode ser fundamentada no baixo CDR. Nelssen et al. (1997) demonstraram que leitões cresceram 8,1\% mais rápido e melhoraram a CA em 5,2\% no período subsequente à moderada restrição de nutrientes. Biker (1994), citado por Nelssen et al. (1997), observou que grande parte deste efeito (ganho compensatório) é consequência do aumento de peso dos órgãos metabolicamente ativos, e não no crescimento em carne magra. Todavia, o CDR dos animais do tratamento extrato vegetal continuou baixo no período de 15-35 dias de experimentação. Portanto, a hipótese de ganho compensatório tem poucas chances de ser aceita, neste caso. Serão necessários maiores estudos a respeito do efeito dos extratos vegetais sobre as secreções digestivas, incluindo a quantificação da atividade catalítica das principais enzimáticas, para o esclarecimento da provável melhora na CA.

\subsubsection{Freqüência de diarréia}

As percentagens médias de ocorrência de diarréias, assim como as médias

transformadas pela função $y=\operatorname{arcsen} \sqrt{(p / 100)}$ estão apresentadas na Tabela 13, para os períodos de um a 14, 15 a 35 e um a 35 dias de experimentação. Já as Tabelas A10, A11 e A12 (Apêndice) apresentam os totais de escores fecais por baia, respectivamente, para períodos de um a 14, 15 a 35 e um a 35 dias de experimentação.

A freqüência de diarréia não foi alterada $(\mathrm{P}>0,10)$ em nenhum dos períodos analisados. Portanto, nenhum dos tratamentos se destacou no controle de diarréias.

As diarréias no período pós-desmame podem ser causadas pela colonização da superfície epitelial por patógenos, tais como a Escherichia coli enterotoxigênica, Salmonella typhimurium, e Clostridium spp. (Stewart \& Chesson, 1993). Para que haja fixação ao epitélio e colonização, as bactérias patógenas devem penetrar no muco glicoprotéico que reveste a superfície epitelial, o que é conseguido, quer por penetração quimiostática, ou movimento ao longo de lacunas no muco (Vassalo, 1995). Além disso, resíduos alimentares não digeridos e não 
absorvidos servem como substratos para fermentação pela microbiota intestinal, elevando a produção de ácido lático e ácidos graxos voláteis. Estes, juntamente com os resíduos alimentares, ainda restantes, e íons minerais (sódio, potássio e cloreto) aumentam a osmolaridade do conteúdo intestinal. Assim, o processo de reabsorção de água é dificultado e há um afluxo de água para a luz intestinal, desencadeando a diarréia (Etheridge et al., 1984; Nabuurs et al., 1993).

Tabela 13. Médias de frequência de diarréia (MFD, \%) e média transformada (MT) para os períodos de um a 14, 15 a 35 e um a 35 dias de experimentação

\begin{tabular}{lcccccc}
\hline & \multicolumn{2}{c}{ 1-14 dias } & \multicolumn{2}{c}{ Períodos } \\
\multicolumn{1}{c}{ Tratamento } & \multicolumn{2}{c}{ 155 dias } & \multicolumn{2}{c}{1 1-35 dias } \\
& MFD (\%) & MT & MFD (\%) & MT & MFD (\%) & MT \\
\hline Controle & 30,95 & 0,55 & 12,30 & 0,30 & 19,76 & 0,43 \\
Antimicrobiano & 29,17 & 0,53 & 8,93 & 0,24 & 17,02 & 0,39 \\
Probiótico & 31,25 & 0,57 & 12,90 & 0,32 & 20,24 & 0,45 \\
Prebiótico & 20,83 & 0,44 & 12,70 & 0,28 & 15,95 & 0,38 \\
Extrato vegetal & 27,38 & 0,51 & 14,09 & 0,31 & 19,40 & 0,42 \\
$\quad$ Média & 27,92 & 0,52 & 12,18 & 0,29 & 18,48 & 0,41 \\
\multicolumn{1}{c}{ Pr $>$ F } & --- & 0,6653 & --- & 0,9264 & --- & 0,8860 \\
\multicolumn{1}{c}{ CV ${ }^{1}$ (\%) } & --- & 42,33 & --- & 80,91 & --- & 45,62 \\
\hline${ }^{1}$ Coeficiente de variac̃ã
\end{tabular}

Como visto, existem muitas possibilidades que podem causar a diarréia pósdesmame. Acima, são colocadas apenas algumas delas, de forma resumida. Como não houve constatação de diferenças entre os tratamentos $(\mathrm{P}>0,10)$ no controle de diarréias, algum outro fator foi preponderante na causa de diarréias pós-desmame, durante o Experimento II, principalmente no período de um a 14 dias de experimentação. Segundo Kelly \& King (2001), o próprio estresse da separação da porca, o transporte e o novo ambiente podem provocar alterações morfohistológicas importantes, deixando o leitão mais exposto às perturbações intestinais. Os antimicrobianos, por exemplo, foram eficientes na promoção do crescimento, provavelmente, por meio da alteração da microbiota, mas não foram capazes de reduzir a frequência de diarréia, em relação ao tratamento controle. Portanto, pode-se sugerir que outros fatores, que fogem ao espectro de ação dos promotores do crescimento utilizados, foram determinantes na ocorrência de diarréias durante o Experimento II. 


\section{CONCLUSÕES}

Os agentes antimicrobianos são eficientes e promoveram o crescimento de leitões recém-desmamados, melhorando a digestibilidade aparente de nutrientes e o ganho diário de peso.

O probiótico, que não apresentou nenhum benefício aos animais, deve ser mais estudado, para que se possa adequar o microrganismo e a quantidade adicionada à dieta de acordo com o desafio encontrado em cada situação.

Dentre todas as alternativas aos antimicrobianos testadas, o prebiótico mananoligossacarídeo foi a mais eficiente, apresentando desempenho equivalente aos animais do tratamento antimicrobiano nos primeiros 14 dias pós-desmame, mas sem melhorar a conversão alimentar. Nos períodos 15 a 35 e um a 35 dias de experimentação, o desempenho dos animais do tratamento prebiótico foi intermediário entre o tratamento controle e antimicrobiano. Assim, o mananoligossacarídeo pode ser entendido como uma alternativa ao uso de antimicrobianos na dieta de suínos recém-desmamados, como promotor do crescimento.

Os extratos vegetais aumentaram o peso relativo do pâncreas dos animais e foram capazes de melhorar, em alguns aspectos, a integridade do epitélio intestinal do duodeno e jejuno. De maneira menos intensa que os antimicrobianos, também melhorou a digestibilidade aparente dos nutrientes. Já o desempenho dos leitões recém-desmamados foi prejudicado pelo baixo consumo de ração.

Os promotores do crescimento utilizados não alteram a microbiota intestinal e não reduziram a frequência de diarréia de leitões recém-desmamados. 


\section{REFERÊNCIAS BIBLIOGRÁFICAS}

ADER, P.; WESSMANN, A.; WOLFFRAM, S. Bioavailability and metabolism of the flavonol quercetin in the pig. Free Radical Biology \& Medicine, v.28, p.1056-1067, 2000.

AHMAD, I.; MEHMOOD, Z.; MOHAMMAD, F. Screening of some Indian medicinal plants for their antimicrobial properties. Journal of Ethnopharmacology, v.62, p.183-193, 1998.

AMAGASE, H.; PETESCH, B.L.; MATSUURA, H.; KASUGA, S.; ITAKURA, Y. Intake of garlic and its bioactive components. Journal of Nutrition, v.131, suppl. 3, p.955S-962S, 2001.

ANDERSON, D.B.; McCRACKEN, V.J.; AMINOV, R.I.; SIMPSON, J.M.; MACKIE, R.I.; VERSTEGEN, M.W.A.; GASKINS, H.R. Gut microbiology and growth-promoting antibiotics in swine. Pig News Information, v.20, p.115N-122N, 1999.

ANDREATTI FILHO, R.L.; SAMPAIO, H.M. Probioticos e prebióticos. Revista Educação Continuada do CRMV-SP, v.2, p.59-71, 1999.

APAJALAHTI, J.; BEDFORD, M.R. Improve bird performance by feeding its microlora. World Poultry, v.15, p.20-23, 1999.

ARAÚJO, C.A.C.; LEON, L.L. Biological activities of Curcuma longa L. Memorandos do Instituto Oswaldo Cruz, v.96, p.723-728, 2001.

ASSOCIATION OF OFFICIAL ANALYTICAL CHEMISTS. Official methods of analysis. 13.ed. Washington, 1980. 1025p.

BARBIN, D. Planejamento e análise estatística de experimentos agropecuários. Arapongas: Midas, 2003. 194p.

BAYNES, P.; VARLEY, M. Gut health: pratical considerations. In: VARLEY, M.A.; WISEMAN, J. (Ed). The weaner pig: nutrition and management. Nothingham: CABI Publishing, 2001. cap.12, p. 249-257. 
BELLAVER, C. O uso de microingredientes (aditivos) na formulação de dietas para suínos e suas implicações na produção e na segurança alimentar. In: CONGRESSO MERCOSUL DE PRODUÇÃO SUÍNA, Buenos Aires, 2000. Anais. Buenos Aires: FCV,UBA; FAV,UNRC; EMBRAPA, 2000. p.93108.

BERG, R.D. Probiotics, prebiotics or `conbiotics'? Trends in Microbiology, v.6, p.89-91, 1998.

BOMBA, A.; KRAVJANSKY, I.; KASTEL, R.; HERICH, R.; JUHÁSOVÁ, Z.; CIZEK, M; KAPITANCÍK, B. Inhibitory effects of Lactobacillus casei upon the adhesion of enterotoxigenic Escherichia coli K99 to the intestinal mucosa in gnobiotic lambs. Small Ruminant Research, v.23, p.199-206, 1996.

BOTERMANS, J.A.M.; PIERZYNOWSKI, S.G. Relations between body weight, feed intake, daily weight gain, and exocrine pancreatic secretion in chronically catherized growing pigs. Journal of Animal Science. v.77, p.450-456, 1999.

BOTERMANS, J.A.M.; KURIA, M.; SVEBDSEN, J.; LUNDH, T.; PIERZYNOWSKI, S.G. The role of the exocrine pancreas in pig performance and amino acid absorption. In: LINDBERG, J.E.; OGLE, B (Ed). Digestive physiology of pigs. Wallingford: CABI Publishing, 2001. cap.46, p. 178-180.

BRESSANI, M.A. Incidência de bactérias do grupo Bacteróides fragilis em crianças imunodeprimidas na cidade de São Paulo. São Paulo, 2001, 80p. Dissertação (Mestrado) - Instituto de Ciências Biomédicas, Universidade de São Paulo.

BRUGALLI, I. Alimentação alternativa: a utilização de fitoterápicos ou nutracêuticos como moduladores da imunidade e desempenho animal. In: SIMPÓSIO SOBRE MANEJO E NUTRIÇÃO DE AVES E SUÍNOS, Campinas, 2003. Anais. Campinas: CBNA, 2003. p.167-182.

BUDIÑO, F.E.L. Probiótico e/ou prebiótico na dieta de leitões recém-desmamados. Jaboticabal, 2004, 75p. Tese (Doutorado) - Faculdade de Ciências Agrárias e Veterinárias, Universidade Estadual Paulista "Júlio de Mesquita Filho".

BURRIN, D.G.; STOLL, B.; VAN GOUDOEVER, J.B.; REEDS, P.J. Nutrient requirements for intestinal growth and metabolism in the developing pig. In: LINDBERG, J.E.; OGLE, B (Ed). Digestive physiology of pigs. Wallingford: CABI Publishing, 2001. cap.19, p. 75-88. 
BUTOLO, J.E. Uso de aditivos na alimentação de aves: frangos de corte. In: SIMPÓSIO SOBRE AS IMPLICAÇÕES SÓCIO-ECONÔMICAS DO USO DE ADITIVOS NA PRODUÇÃO ANIMAL, Piracicaba, 1999. Anais. Piracicaba: CBNA, 1999. p.85-98.

CAIM, C.M.; ZIMMERMAN, D.R. Effect of spray dried plasma (SDP) on faecal shedding of hemolytic E. coli (HEC) and rotavirus by pigs in a segregated early-weaned (SEW) environment. Journal of Animal Science. v.75, suppl. 1, p.61, 1997.

CERA, K.R.; MAHAN, D.C.; CROSS, R.F. REINHART, G.A.; WHITMOYER, R.E. Effect of age, weaning and postweaning diet on small intestinal growth and jejunal morphology in young swine. Journal of Animal Science, v.66, p.574-584,1988.

CHANG, S.T.; CHEN, P.F.; CHANG, S.C. Antibacterial activity of leat essential oil and their constituents from Cynnamomun osmophlocum. Journal of Ethnopharmacology. v.77, p.123-127, 2001.

CHATEAU, N.; CASTELLANOS, I.; DESCHAMPS, A.M. Distribution of pathogen inhibitionin the Lactobacillus isolates of a commercial probiotic consortium. Journal of Applied Bacteriology, v.74, p.36-40, 1993.

CHEESON, A. Probiotics and other intestinal mediators. In: COLE, D.J.A.; WISEMAN, J.; VARLEY, M.A. (Ed.). Principles of pig science. Nothingham: University Press of Nothingham, 1994. cap.13, p. $197-214$.

CICHEWICZ, R. H.; THORPE, P. A. The antimicrobial properties of chile peppers (Capsicum species) and their uses in Mayan medicine. Journal of Ethnopharmacology. v.42, p.61-70, 1996.

COLLET, S. Nutrição, imunidade e produtividade. In: RONDA LATINOAMERICANA E DO CARIBE DA ALLTECH, 10., Campinas, 2000. Anais. Campinas: ALLTECH, 2000. p.20-30.

COLLINS, M.D.; GIBSON, G.R. Probiotics, prebiotics and synbiotics: approaches for modulating the microbial ecology of the gut. American Journal of Clinical Nutrition, v.69, suppl. 1, p.1052S, 1999.

COMPÊNDIO BRASILEIRO DE ALIMENTAÇÃO ANIMAL. Microingredientes: microingredientes de alimentação animal. Brasília: CARC,MA; CBNA; SINDIRAÇÕES,ANFAL. 1998. 45p.

CORPET, D.E. Mechanism of antimicrobial growth promoters used in animal feed. Review of Medicine Veterinary. v.151, p.99-104, 2000. 
CORRING, T.; JUSTE, C.; LHOSTE, E.F. Nutritional regulation of pancreatic and biliary secretions. Nutrition Research Reviews. v.2, p.161-180, 1989.

CROMWELL, G. L. Antimicrobial agents. In: MILLER, E.R., ULLREY, D.E., LEWIS, A.J. (Ed.). Swine nutrition. Stoneham: Butterworth-Heinemann, 1991. cap.17, p. 297-315.

CUMMINGS, J.H; MACFARLANE, G.T. The control and consequences of bacterial fermentation in the human colon. Journal of Applied Bacteriology. v.70, p.443-459, 1991.

DAWSON, K.A.; PIRVULESCU, M. Mananologossacarídeos derivados de leveduras como moduladores da resposta imunológica e alternativas aos promotores de crescimento antimicrobianos. In: RONDA LATINOAMERICANA E DO CARIBE DA ALLTECH, 8., Campinas, 1999. Anais. Campinas: ALLTECH, 1999. p.33-41.

DEVEGOWDA, G. Micotoxinas na ração: um problema unversal e inovadoras soluções biotecnológicas naturais. In: RONDA LATINOAMERICANA E DO CARIBE DA ALLTECH, 7., Campinas, 1997. SP. Anais. Campinas: ALLTECH, 1997. p.45-59.

DONOHUE, D.C.; SALMINEN, S. Safety assessment of probiotic bactéria. Asia Pacific Journal of Clinic Nutrition. v.5, p.25-28, 1996.

DORIA, R.F.A. Ação antioxidante de extratos etanólicos de alecrim (Rosmarinus officinalis L.) e orégano (Origanum vulgare L.) em óleo de soja submetido a termoxidação e fotoxidação. Piracicaba, 1999. 71p. Dissertação (Mestrado) - Escola Superior de Agronomia “Luiz de Queiroz”, Universidade de São Paulo.

DORMAN, H.J.D.; DEANS, S.G. Antimicrobial agents from plants: antibacterial activity of plant volatile oil. Journal of Applied Microbiology, v.83, p.308-316, 2000.

ESSAWI, T.; SROUR, M. Screening of some Palestinian medicinal plants for antibacterial activity. Journal of Ethno-pharmacology, v.70, p.343-349, 2000.

ETHERIDGE, R.D.; SEERLEY, R.W.; WYATT, R.D. The effect of the diet on performance, digestibility, blood composition and intestinal microflora of weaned pigs. Journal of Animal Science, v.58, p.1396-1402, 1984.

FAO. http://apps.fao.org/page/collections?subset=agriculture (16 fev. 2004a). 
FAO. http://apps.fao.org/lim500/wrap.pl?Population.LTI\&Domain=SUA\&Language $=$ english $(16 \mathrm{fev}$. 2004b).

FERKET, P.R. Use of oligosaccharides and gut modifiers as replacements for dietary antibiotics. In: MINNESOTA NUTRITION CONFERENCE, 63., Indianapolis, 2002. Proceedings. Indianapolis: UIL, 2002. p.169-182.

FERKET, P.R. Manutenção da saúde intestinal em um mundo sem antibióticos. In: RONDA LATINOAMERICANA DA ALLTECH, 13., Campinas, 2003. SP. Anais. Campinas: ALLTECH, 2003. p.26-39.

FUKUSHIMA, Y.; KAWATA, Y.; HARA, H.; TERADA, A.; MITSUOKA, T. Effect of a probiotic formula on intestinal immunoglobulin A production in healthy children. International Journal of Food and Microbiology, v.42, p.39-44, 1998.

FULLER, R. Probiotics in man and animals. Journal of Applied Bacteriology, v.66, p.356-378, 1989.

GANESH-BAHT, B.; SRINIVASAN, M.R.; CHANDRAEKHARA, N. Influence of curcumin and capsaicin on the composition and secretion of bile in rats. Journal of Food Science and Technology, v.21, p.225-227, 1984.

GATNAU, R.; CAIN, C.; DREW, M.; ZIMMERMAN, D.R. Mode of action of spray-dried porcine plasma in weanling pigs. Journal of Animal Science, v.73, suppl. 1, p.82, 1995.

GIBSON, G.R.; ROBERFROID, M.B. Dietary modulation of the human colonic microbiota: introducing the concept of prebiotcs. Journal of Nutrition, v.125, p.1401-1412, 1995.

GILLIAND, S.E. Probiotics: fact or fancy? In: INTERNATIONAL BIOTECHNOLOGY SYMPOSIUM, Paris, 1988. Anais. Paris: Societé Française de Microbiologis, 1988. v.2, p.923-933.

GRELA, E.R.; KRUSINSKA, R.; MATRAS, J. Efficacy of diets with antibiotic and herb mixture additives in feeding of growing-finishing pigs. Journal of Animal and Feed Science. v.7, suppl. 1, p.171-175, 1998.

GUARRERA, P.M. Tradicional antihelmintic, atiparasitic and repellent uses of plants in Central Italy. Journal of Ethnopharmacology, v.68, p.183-192, 1999.

GUILLOT, J.F. The pros and cons of probiotics - make probiotics work for poultry. Feed Mix, v.23, n.8, p.28-30, 2000. Número especial. 
GUO, F.C.; WILLIAMS, B.A.; KWAKKEL, R.P.; LI, H.S.; LI, X.P.; LUO, J.Y.; LI, W.K.; VERSTEGEN, M.W.A. Effects of mushroom and herb polysaccharides, as alternatives for an antibiotic, on the cecal microbial ecosystem in broiler chickens. Poultry Science, v.83, p.175-182, 2004.

GUPTA, A.; SANDHU, R.S. In vivo binding of mannose specific lectin from garlic to intestinal epithelium. Nutrition Research, v.17, p. 703-711, 1997.

GUPTA, A.; SANDHU, R.S. Effect of garlic agglutinin and garlic extracts on the rat jejunun. Nutrition Research, v.18, p.841-850, 1998.

GUSTAFSON, R.H.; BOWEN, R.E. Antibiotic use in animal agriculture. Journal of Applied Microbiology, v.83, p.531-541, 1997.

HAMPSON, D.J., KIDDER, D.E. Influence of creep feeding and weaning on brush border enzyme activities in the piglet small intestine. Research Veterinary Science. v.40, p.24-31, 1986.

HARDY, B. The issue of antibiotic use in the livestock industry: what have we learned????. In: CONFERENCE ON ANTIBIOTIC USE IN ANIMAL AGRICULTURE, 13., Fairmont, MN, 2002. Anais. Fairmont: UMN, 2002. p.129-147.

HARRIS, J.C.; COTTREL, S.L.; PLUMMER, S.; LLOYD, D. Antimicrobial properties of Allium sativum (garlic). Applied Microbiology Biotechnology, v.57, p.282-286, 2001.

HAYES, D.J.; JENSEN, H.H.;FABIOSA, J. Technology choice and the economic effects of a ban on the use of antimicrobial feed additives in swine rations. Food Control, v.13, p.97-101, 2002.

HEDEMANN, M.S.; JENSEN, S.K. The activity of lipolytic enzymes is low around the weaning measurements in pancreatic tissue and small intestine contents. In: LINDBERG, J.E.; OGLE, B (Ed.). Digestive physiology of pigs. Wallingford, UK: CABI Publishing, 2001. cap.6, p. 28-30.

HEDEMANN, M.S.; HOJSGAARD, S.; JENSEN, B.B. Small intestinal morphology and activity of intestinal peptidases in piglets around weaning. Journal of Animal Physiology and Animal Nutrition. v.87, p.32-41, 2003.

HENRIQUE, A.P.F. Efeito do antibiótico, probiótico e ácidos orgânicos e suas combinações sobre o desempenho e rendimento de carcaça de frangos de corte. Pirassununga, 1998. 88p. Dissertação (Mestrado) - Faculdade de Zootecnia e Engenharia de Alimentos, Universidade de São Paulo. 
HENRY, P., AMMERMAN, C.B., CAMPBELL, D.R., et al. Effect of antibiotics on tissue trace mineral concentration and intestinal tract weight of broiler chicks. Poultry Science, v.66, p.1014-1018, 1987.

HERNANDÉZ, F.; MADRID, J.; GARCÍA, V.; ORENGO, J.; MEGÍAS, M.D. Influence of two plant extracts on broilers performance, digestibility, and digestive organ size. Poultry Science. v.83, p.169174, 2004.

HOLZPAFEL, W.H.; HABERER, P.; SNEL, J.; SCHILINGER, U.; VELD, J.H.J.H. Overview of gut flora and probiotics. International Journal of Food Microbiology, v.41, p.85-101, 1998.

HOOGE, D.M. Antibiotic and their alternatives for poultry examined. Feedstuffs. v.71, p.59-61 e 75-76, 1999.

HOOGE, D.M. Bacillus spores may enhance broiler performance. Feedstuffs. v.75, p.28-32, 2003.

HORTON, G.M.J.; BLETHEN, D.B.; PRASAD, B.M. The effect of garlic (allium sativum) on feed palatability of horses and feed consumption, selected performance and blood parameters in sheep and swine. Canadian Journal of Animal Science. v.71, p.607-610, 1991.

HUYGHEBAERT, G. Replacement of antibiotics in poultry. In: EASTERN NUTRITION CONFERENCE, 2003, Quebec City. Anais. Quebec City: UON, 2003. p.1-23.

JENSEN, B.B. The impact of feed additives on the microbial ecology of the gut in young pigs. Journal of Animal and Feed Sciences. v.7, p.45-64, 1998.

JENSEN, J.F.; JENSEN, M.M. The effect of using growth promoting Bacillus strains in poultry. In: WORLD’S POULTRY CONGRESS, 13., 1992, Amsterdam. Anais. Amsterdam: WPSA, 1992. v.3, p.398-402.

JIN, L.Z.; HO, Y.W.; ZHAO, X. Probiotics in poultry: modes of action. World's Poutry Science Journal. v.53, p.351-368, 1997.

JIN, L.; REINOLDS, L.P.; REDNER, D.A.; CATON, J.S.; CRENSHAW, J.D. Effects of dietary fiber on intestinal growth, cell proliferation, and morphology in growing pigs. Journal of Animal Science. v.72, p.2270-2278, 1994.

JONG, E.U., LEBOUTE, E.M., CIOCCA, M.L., et al. Uso de avoparcina e virginiamicina como promotores de crescimento em rações de frangos de corte. 2. Efeito sobrea flora intestinal e estrutura física do intestino. Revista da Sociedade Brasileira de Zootecnia, v.14, p.536-542, 1985. 
JORGENSEN, M. Probiotics - a survey. An alternative to antibiotics in feed of furbearing animals? Scientifur. v.12, p.247-249, 1989.

KAILA, M.; ISOLAURI, E.; SOPPI, E.; VIRTANEN, E.; LAINE, S.; AVILOMMI, H. Enhancement of circulating antibody secreting cell response in humen dianhea by human Lactobacillus strain. Pediatric Research. v.32, p.141-144, 1992.

KAMEL, C. A novel look at a classic approach of plant extracts. Feed Mix, v.9, n.6, p.19-24, 2000. Número especial.

KARANIKA, M.S.; KOMAITIS, M.; AGGELIS, G. Effect of aqueous extract of some plants of Lamiaceae family on the growth of Yarrowia lipolytica. International Journal of Food Microbiology, v.64, p.175-181, 2001.

KATS, L.J., NELSSEN, J.L.; TOKACH, M.D.; GOODBAND, R.D.; HANSEN, J.A.; LAURIN, J.L. The effect of spray-dried porcine plasma on growth performance in the early-weaned pig. Journal of Animal Science, v.72, p.2075-2081, 1994.

KELLY, D.; KING, T.P. Digestive physiology and development in pigs. In: VARLEY, M.A.; WISEMAN, J. (Ed.). The weaner pig: nutrition and management. Nothingham, UK: CABI Publishing, 2001. cap.9, p. 179-206.

KOHLERT, C; VAN RENSEN, I.; MARZ, R.; SCHINDLER, G.; GRAEFE, E.U.; VEIT, M. Bioavailability and pharmokinetics of natural volatile terpenes in animal and humans. Planta Medica, v.66, p.495-505, 2000.

KREUZER, M. Probiotic-antibiotic interatctios in performance, intestinal fermentation and manure properties of piglets using a Bacillus (Bacillus subtilis e Bacillus licheniformis) preparation and carbadox. Agrobiological Research-zeitschrift fur Agrobiologie Agrikulturchemie Okologie. v.47, p.13-23, 1994. (abstract)

KRIEG, N.R.; HOLT, J.C. Bergey's manual of systematic bacteriology. 9 ed. Baltimore: Willians \& Wilkins, 1994. 215 p.

LAMBERT, R.J.W.; SKANDAMIS, P.N.; COOTE, P.J.; NYCHAS, G.J.E. A study of the minimum inhibitory concentration and mode of action of oregano essential oil, thymol and carvacrol. Journal of Applied Microbiology, v.91, p.453-462, 2001. 
LANCINI, J.B. Fatores exogenous na função gastrointestinal, aditivos. IN: FUNDAÇÃO APINCO DE CIÊNCIAS E TECNOLOGIA, Campinas, 2000. Anais. Campinas: APINCO, 1994. p.99-126.

LANGHOUT, P. New additives for broiler chickens. Feed Mix, v.18, n.6, p.24-27, 2000. Número especial.

LEEDLE, J. Intestinal microbiology - action mechanisms. In: SIMPÓSIO SOBRE ADITIVOS ALTERNATIVOS NA NUTRIÇÃO ANIMAL. Campinas, 2000. Anais. Campinas: CBNA, 2000a. p.1-14.

LEEDLE, J. Probiotics and DFM's - Mode of action in the gastrointestinal tract. In: SIMPÓSIO SOBRE ADITIVOS ALTERNATIVOS NA NUTRIÇÃO ANIMAL, Campinas, 2000. Anais. Campinas: CBNA, 2000b. p.25-40.

LENNETTE, J.K.; SPAUDING, L.H.; TRUANT, J.P. Manual of clinical microbiology. Washington: American Society for Microbiology, 1985. 314p.

LILLIE, R.D.; FULLMER, H. Histopatologic technic and pratical histochemistry. 4 ed. New York: McGraw-Hill, 1976. 942 p.

LIMA, G.J.M.M. Uso de aditivos na produção de suínos. In: SIMPÓSIO SOBRE AS IMPLICAÇÕES SÓCIO-ECONÔMICAS DO USO DE ADITIVOS NA PRODUÇÃO ANIMAL, Piracicaba, 1999. Anais. Piracicaba: CBNA, 1999. p.51-68.

LIMA, G.J.M.M.; RUTZ, F.; BORGES, S.A.; VIOLA, E.S.; Efeito da adição de um composto de ervas naturais como promotor de crescimento de dietas de suínos em crescimento e terminação. In: CONGRESSO BRASILEIRO DE VETERINÁRIOS ESPECIALISTAS EM SUÍNOS, 10., Foz do Iguaçu, 2001. Resumos. Foz do Iguaçu: ABRAVES, 2001. p. 323-324.

LIN, H.C.; VISEK, W.J. Colon mucosal cell damage by ammonia in rats. Journal of Nutrition, v.121, p.887-893, 1991.

LINDEMANN, M.D. Effect of age , weaning and diet on digestive enzyme levels in the piglet. Journal of Animal Science, v.62, p.1298-1307, 1986.

LOPEZ-BOTE, C.J.; GRAY, J.K.; GOMAA, E.A.; FLEGAL, C.J. Effect of dietary administration of oil extracts from rosemary and sage on lipid oxidation in broiler meat. British Poultry Science, v.39, p.235-240, 1998. 
MACARI, M.; MAIORKA, A. Função gastrintestinal e seu impacto no rendimento avícola. In: CONFERÊNCIA APINCO’2000 DE CIÊNCIA E TECNOLOGIA AVÍCOLAS, Campinas, 2000. Anais. Campinas: FACTA, 2000. p.1.61-174.

MADSEN, H.L.; BERTELSEN, G. Spices as antioxidants. Trends in Food Science and Technology, v.6, p.271-277, 1995.

MAHASNEH, A.M.; EL-OQLAH, A.A. Antimicrobial activity of extracts of herbal plants used in the traditional medicine of Jordan. Journal of Ethnopharmacology, v.64, p.271-276, 1999.

MAHMOUD, A.L.E. Antifungal action and antiaflatoxigenic properties of some essential oils constituents. Letters in Applied Microbiology, v.19, p.110-113, 1994.

MAHROUR, A.; LACROIX, M.; NKETSA-TABIRI, J.; CALDERON, N.; GAGNON, M. Antimicrobial properties of natural substances in irradiated fresh poultry. Radiation Physics Chemistry, v.52, p.8184, 1998.

MAISONNEUVE, S.; OURIET, M.F.; DUVAL-IFLASH, Y.S. Comparison of yogurt, heat-treated yogurt, milk and lactose effects on plasmid dissemination in gnotobiotic mice. Antonie Van Leeuwenhoek, v.79, p.199-207, 2001.

MARTINEZ, M.J.; BETANCOURT, J.; ALONSO-GONZÁLEZ, N.; JAUREGUI, A. Screening of some Cuban medicinal plants for antimicrobial activity. Journal of Ethnopharmacology, v.52, p.171-174, 1996.

MARTINS, E.R.; CASTRO, D.M.; CASTELLANI, D.C.; DIAS, J.E. Plantas Medicinais. Viçosa, MG: UFV, 2000. 220p.

MATHEW, A.G.; SUTTON, A.L.; SCHEIDT, A.B.; PATTERSON, J.A.; KELLY, D.T.; MEYERHOLTZ, K.A. Effect of galactan on seletcted microbial populations and $\mathrm{pH}$ and volatile fatty acids in the ileum of the weanling pig. Journal of Animal Science, v.71, p.1503-1509, 1993.

MATTERSON, L.D.; POTTER, S.N.; STUTZ, M.W. et al. The metabolizable energy of feed ingredients for chikens. Storrs, Connecticut: University of Connecticut, Agricultural Experiment Station. 11p. (Research Report, 7), 1965.

MELLOR, S. Alternatives to antibiotic. Pig Progress, v.16, p.18-21, 2000. 
MENTEN, J.F.M. Effects of high dietary copper on the utilization of nutrients and blood and intestinal variables of starter pigs. Michigan, 1988. 122p. Dissertation (PhD) - Michigan State University.

MENTEN, J.F.M. Eficácia, efeito sinérgico e modo de ação de agentes antimicrobianos como promotores do crescimento de suínos. Piracicaba, 1995. 106p. Tese (Livre Docência) - Escola Superior de Agricultura “Luiz de Queiroz”, Universidade de São Paulo.

MENTEN, J.F.M. Aditivos alternativos na produção de aves: probióticos e prebióticos. In: REUNIÃO ANUAL DA SOCIEDADE BRASILEIRA DE ZOOTECNIA, 38., Piracicaba, 2001. Anais. Piracicaba: FEALQ, 2001. p.141-157.

MILLER, B.G.; NEWBY, T.J.; STOKES, C.R. BOURNE, F.J. Influence of diet o postweaning malabsorption and diarrhea in the pig. Research Veterinary Science, v.36, p.187-193, 1984.

MOLLY, K. Formulating to solve the intestinal puzzle. Pig Progress, v.17, p.20-22, 2001.

MORES N.; SOBESTIANSKY, J.; WENTZ, I.; MORENO, A.M. Manejo do leitão desde o nascimento até o abate. In: SOBESTIANSKY, J.; WENTZ, I.; SILVEIRA, P.R.S.; SESTI, L.A.C. (Ed.). Suinocultura Intensiva. Concórdia: EMBRAPA, 1998. cap.7, p. 135-162.

MOREIRA, I. Valor nutritivo e utilização de milho e soja integral processados a calor na alimentação de leitões. Viçosa, 1993. 145p. Tese (Doutorado) - Universidade Federal de Viçosa.

MOTOHASHI, Y.; FUKUSHIMA, A.; KONDE, T.; SAKUMA, K. Lactose decline in weaning rats is regulated at transcriptional level and not caused by termination of milk ingestion. Journal of Nutrition, v.127, p.1737-1745, 1997.

MURAMATSU, T.; NAKAJIMA, S.; OKUMURA, J. Modification of the energy metabolism by preence of the gut microflora in the chiken. British Journal of Nutrition, v.71, p.709-717, 1994.

MURATA, K.; MIYAZAKI, H.; MASUDA, S.; TAKAHASHI, M.; MARUBASHI, T.; TADANO, Y.; TAKAHASHI, H. Exclusion of intestinal pathogens by continuous feeding with Bacillus subtilis C3102 and its influence on the intestinal microflora in broilers. Animal Science and Technology, v.67, p.273-280, 1996.

NABUURS, M.J.A. Microbilogical, structural and functional changes of the small intestine of pigs at weaning. Pig News Information, v.16, p.93-97, 1995. 
NABUURS, M.J.A; ZIJDERVELD, F.G.; DE LEEUW, P.W. Villus height and crypt depth in weaned and unweaned pigs, reared under various circumstances in the Netherlands. Research in Veterinary Science, v.55, p-78-84, 1993.

NASCIMENTO, G.G.F.; LOCATELLI, J.; FREITAS, P.C.; SILVA, G.L. Antibacterial activity of plant extracts and phytochemicals on antibiotic resistant bacteria. Brazilian Journal of Microbiology, v.31, p.247-256, 2000.

NASCIMENTO FILHO, V.F.; ABDALA, A.L.; KORNDORFER, C.M.; NAVARRO, A.A.; BUENO, I.C.S. Sensibilidades analíticas de diferentes modos de excitação em fluorescência de raios X para medida de traçadores em fezes de animais. In: ENCONTRO CIENTÍFICO DOS PÓS GRADUANDOS DO CENA/USP, Piracicaba, 1997. Resumos. Piracicaba: CENA, 1997. p.69.

NATIONAL RESEARCH COUNCIL. Subcommittee on Swine Nutrition. Committee on Animal Nutrition. Nutrient Requeriments of Swine. 10.ed. Washington: National Academy Press, 1998. 189p.

NAVARRO, V.; DELGADO, G. Two antimicrobial alkaloids from Bocconia arborea. Journal of Ethnopharmacology, v.65, p.223-226, 1999.

NELSSEN, J.L.; DRITZ, S.S.; TOKACH, M.D.; GOODBAND, R.D. Nutritional programs for earlyweaned pigs. In: CONGRESSO BRASILEIRO DE VETERINÁRIOS ESPECIALISTAS EM SUÍNOS, 8., Foz do Iguaçu, 1997. Anais. Foz do Iguaçu: ABRAVES, 1997. p.126-136.

NEWMAN, K. Mannan-oligosaccharides: natural polymers with significant impact on the gastrointestinal microflora and the immune system. In: ALLTECH'S ANNUAL SYMPOSIUM, 10., 1994, Nottingham, UK. Anais. Nottingham: ALLTECH, 1994. p.167-174.

NEWMAN, K. E., SPRING, P., SNITZER, L. S. Effect of thermal treatment on the ability of mannan oligosaccharide to absorb enteric bacteria. Journal of Animal Science, v.73, suppl. 1, p.310, 1995.

NICHOLSON, W.J.; FAJARDO-CAVAZOS, P.; REBEIL, R.; SLIEMAN, T.A.; RIESENMAN, P.J. Bacterial endospores and their significance in stress resistance. Antonie Van Leeuwenhoek, v.81, p.27-32, 2001.

OLIVEIRA, S.R. Ação antioxidante de extratos de alho (Allium sativum L.) e da cebola (Allium cepa L.) in vitro e em gordura de frango. Viçosa, 1991, 91p. Dissertação (Mestrado) - Universidade Federal de Viçosa. 
OUWEHAND, A.C.; KIRJAVAINEM, P.V.; GRÖNLUND, M.M.; ISOLAURI, E.; SALMINEN, S.J. Adhesion of probiotic micro-organisms to intestinal mucus. International Dairy Journal, v.9, p.623630, 1999.

PETTIGREW, J.E. Mannan oligosaccharides effects on performance reviewed. Feedstuffs, v.72, n. 53, p.12-14, 2000.

PIVA, A.; CERVELlATI, C.; BIAGI, G.; CASADEI, G. High dose of carvacrol, and not oregano, controls swine cecal fermentation. Journal of Animal Science. v.80, p.395, 2002a. Supplement, 1.

PIVA, A.; CERVELLATI, C.; CALL, J.E.; LUCHANSKY, J.B. Effect of carvacrol on indigenous Enterobacteriaceae levels and fermentation system. Journal of Animal Science, v.80, suppl. 1, p.395, 2002b.

POUWELS, P.H.; LEAR, R.J.; BOERSMA, W.J. The potencial of Lactobacillus as a carrier for oral immunization: development and preliminary characterization of vector systems for targeted delivery of antigens. Journal of Biotechnology, v.44, p.183-192, 1996.

POZO, L.A.P. Estudo "in vitro" do efeito de extratos aquosos de plantas medicinais sobre Clostridium difficile. Viçosa, 1997, 77p. Dissertação (Mestrado) - Universidade Federal de Viçosa.

PLATEL, K.; SRINIVASAN, K. Influence of dietary spices or their active principles on digestive enzymes of small intestinal mucosa in rats. International Journal of Food Sciences and Nutrition., v.47, p.55-59, 1996.

PLUSKE, J.R.; WILLIAMS, J.H.; AHERNC, F.X. Maintenance of villus height and crypt depth in pglets by providing continuous nutrition after weaning. Animal Science, v.62, p.131-144, 1996.

PLUSKE, J.R.; HAMPSON, D.J.; WILLIAMS, J.H. Factors influencing the structure and function of the small intestine in the weaned pig: a review. Livestock Production Science, v.51, p.215-236, 1997.

RADFORD, M.; JEAUROUND, E.; SCUMANN, B.; CLUNIES, M.; DE LANGE, C.F.M. Supplementation of diets with herbal extracts enhances growth performance in newly-weaned piglets. Journal of Animal Science, v.80, suppl. 1, p.394, 2002.

RAIDA, M.K.; LARSEN, J.L.; NIELSEN, M.E.; BUCHMANN, K. Enhanced rsistance of rainbow tout, Oncorhynchus mykiss (Walbaum), against Yersinia ruckeri challenge following oral administration of Bacillus subtilis and Bacillus licheniformis (Bio Plus 2B). Journal of Fish Diseases, v.26, p.495-498, 2003. 
REDDY, V.; ROTH, M.N.; EIGEL, S.; PEIRSON, K.L. Probiotics. Journal of Food Protection, v.51, p.71-72, 1988.

RODAS, B.Z.; MILLER, B.L.; WALKER, R.; NELSON, D.A.; MARIN-GUSMAN, J. Dietary botanical product improves performance of nursery pigs. Journal of Animal Science, v.80, suppl. 1, p.394, 2002.

ROSTAGNO, H.S.; ALBINO, L.F.T.; DONZELE, J.L.; GOMES, P.C.; FERREIRA, A.S.; OLIVEIRA, R.F.; LOPES, D.C. Tabelas brasileiras para aves e suínos: composição de alimentos e exigências nutricionais. Viçosa: Universidade de Viçosa, 2000. 141p.

ROTH, L. The battle of the bugs - the direct fed microbial concept. Pig Progress, v.16, p.12-15, 2000.

ROTH, F.X; KIRCHGESSNER, M. Nutritive affects of toyocerin. 1 Piglet feeding. Landwirtschafliche Forschung, v.41, p.58-62, 1988. (abstract).

ROTH, F.X.; KIRCHGESSNER, M. Influence of avilamycin and tylosin on retention and excretion of nitrogen in growing pigs. Journal of Animal Physiology and Animal Nutrition, v.69, p.175-185, 1993.

SALVAT, A.; ANTONNACCI, L.; FORTUNATO, R.H.; SUAREZ, E.Y.; GODOY, H.M. Screening of some plants from northern Argentina for their antimicrobial activity. Letters in Applied Microbiology, v.32, p.293-297, 2001.

SAMBAIAH, K.; SRINIVASAN, K. Secretion and composition of bile in rats fed diets containing spices. Journal of Food Science and Technology, v.28, p.35-38, 1991.

SANTOS, W.G.; FILGUEIRAS, E.P.; BERTECHINI, A.G.; SILVA, H.O; OLIVEIRA, R.F.M.; LOPES, D.C.; SILVA, M.C. Efeito da monose como prebiótico sobre a morfologia intestinal de leitões na fase de creche. In: REUNIÃO ANUAL DA SOCIEDADE BRASILEIRA DE ZOOTECNIA, 34., Recife, PE, 2002a. Anais. Recife: SBZ, 2002a. (compact disc).

SANTOS, W.G.; FILGUEIRAS, E.P.; SILVA, H.O; BERTECHINI, A.G.; FIALHO, E.T.; SILVA, M.C.; FARIA, W.G. Efeito da monose como prebiótico sobre a morfologia intestinal (relação vilosidade/cripta) de leitões na fase de creche. In: REUNIÃO ANUAL DA SOCIEDADE BRASILEIRA DE ZOOTECNIA, 34., Recife, PE, 2002b. Anais. Recife: SBZ, 2002b. (compact disc). 
SAVAGE, T.F.; COTTER, P.F.; ZAKREWSKA, E.I. The effect of feeding a mannan oligosaccharide on imunoglobulins, plasma IgG and bile IgA of Wrolstad MW male turkeys. Poultry Science, v.75, suppl. 1, p.129S, 1996. (Abstract)

SAVAGE, T.F.; ZAKREWSKA, E.I; ANDREASEN, J.R. The effects of feeding mannanoligosaccharide supplemented diets to poults on performance and the morphology of the small intestine. Poultry Science, v.76, suppl. 1, p.139S, 1997. (Abstract)

SCARCELLI, E.; GENOVEZ, M.E.; CARDOSO, M.V.; SOUZA, M.C.A.M.; GRASSO, L.M.P.S.; SOUZA, C.A.I.; TORRES, A.P. Avaliação do potencial de disseminação de Campylobacter spp por diferentes espécies animais. Arquivos do Instituto Biológico, v.65, p. 56-61, 1998.

SCHWABB, J.H. Phlogistic properties of peptido-glycan-polysaccharide polymers from cell walls of pathogenic and normal-flora bacteria wich colonise humans. Infect Immunology, v.61, p.4535-4539, 1993.

SILVA, E.N. Antibióticos intestinais naturais: bacteriocinas. In: SIMPÓSIO SOBRE ADITIVOS ALternAtivos NA NUTRIÇÃO ANIMAL, Campinas, 2000. Anais. Campinas: CBNA, 2000. p.15-24.

SIMPSON, J.M.; McCRAKEN, V.J.; WHITE, B.A.; GASKINS, H.R.; MACKIE, R.I. Application of denaturant gel electrophoresis for the analysis of the porcine gastrointestinal microbiota. Journal of Microbiology Methods, v.36, p.167-179, 1999.

SMINK, W. Oregano oil boost. Pig Progress, v.19, n.3, p. 24-26, 2003.

SONCINI, R.A. Restrições do uso de aditivos na alimentação animal: expectativa da agroindústria. In: SIMPÓSIO SOBRE AS IMPLICAÇÕES SÓCIO-ECONÔMICAS DO USO DE ADITIVOS NA PRODUÇÃO ANIMAL, Piracicaba, 1999. Anais. Piracicaba: CBNA, 1999. p.99-104.

SPRING, P. Yeast`s secret weapon aids animal production. In: SIMPÓSIO SOBRE ADITIVOS ALterANTIVOS NA NUTRIÇÃO ANIMAL. Campinas, 2000. Anais. Campinas: CBNA, 2000. p.41-50.

SREENIVASAMURTHY, V.; KRISHNAMURTHY, K. Place of spices and aromatics in Indian dietary. Food Science, v.8, p.284-288, 1959. 
SRINIVASAN, D.; NATHAN, S.; SURESH, T.; PERUMALSAMY, P.L. Antimicrobial activity of certain Indian medicinal plants used in folkloric medicine. Journal of Ethnopharmacology, v.74, p.217-220, 2001.

STATISTICAL ANALYSIS SYSTEM INSTITUTE. SAS user's guide: statistics. Carry, 2001. 155p.

STEWART, C.S.; CHESSON, A. Making sense of probiotics. Pig Veterinary Journal, v.31, p.11-33, 1993.

TABAK, M.; ARMONM R.; NEEMAN, I. Cinnamon extracts inhibitory effect on Helicobacter pylori. Journal of Ethnopharmacology, v.67, p.169-277, 1991.

TANNOCK, G.W. Influences of the normal microbiota on the host animal. In: MACKIE, R.I. (Ed.) Gastrointestinal Microbiology. London: Chapman and Hall, 1997. cap.18, p. 466-497.

TAVARES, W. Manual de antibióticos e quimioterápicos antiinfecciosos. Rio de Janeiro: Livraria Atheneu Editora, 1990. 515p.

TUCCI, F.M. Efeitos da adição de agentes tróficos na dieta de leitões desmamados sobre a renovação celular da mucosa intestinal, enzimas digestivas e desempenho. Jaboticabal, 2003, 84p. Tese (Doutorado) - Faculdade de Ciências Agrárias, Universidade Estadual Paulista "Júlio de Mesquita Filho".

TURNER, J.L; DRITZ, P.S.S.; MINTON, J.E. Review: Alternatives to conventional antimicrobials in swine diets. The Professional Animal Scientist, v.17, p.217-226, 2001.

URAO, M.; FUJIMOTO, T.; LANE, G.J.; SEO, G.; MIYANO, T. Does probiotics administration decrease serum endotoxin levels in infants. Journal of Pediatric Surgery, v.34, p.273-276, 1999.

VAN BEER-SCHUREURS, H.M.G; NABUURS, M.J.A.; VELLENGA, L.; VAN DER VALK, H.J.K.; WENSING, T.; BREUKINK, H.J. Weaning and the weaning diet influence the vilous height and crypt depth in the small intestine of pigs and alter the concentrations of short-chain fatty acids in the large intestine and blood. Journal of Nutrition, v.128, p.947-953, 1998.

VANBELLE, M.; TELLER, E.; FOCANT, M. Probiotics in animal nutrition: a review. Archives of Animal Nutrition, v.40, p.543-567, 1990.

VASSALO, M. Probióticos em rações para leitões dos 10 aos 30 kg de peso vivo. Lavras, 1995, 50p. Dissertação (Mestrado) - Universidade Federal de Lavras. 
VENTE-SPREEUWENBERG, M.A.M.; VERDONK, J.M.A.J.; BAKKER, G.C.M.; BEYNEN, A.C.; VERSTEGEN, M.W.A. Effect of dietary protein source on feed intake and small intestinal morphology in newly weaned piglets. v.58, 2004. (no prelo).

VIEIRA, R.H.S.F; RODRIGLES, D.P.; GONÇALVEZ, F.A; MENEZES, F.G.R.; ARAGÃO, J.S.; SOUSA, O.V. Microbicidal effect of medicinal plant extract (psidium guajava Linn and Carica papaya Lin) upon bactéria isolated from fish muscle and known to induce diarrhea in children. Revista do Instituto de Medicina Tropical de São Paulo, v.43, p.145-148, 2001.

VIOLA, E.S.; VIEIRA, S.L. Ácidos orgânicos e suas misturas em dietas de suínos. In: SIMPÓSIO SOBRE MANEJO E NUTRIÇÃO DE AVES E SUÍNOS. Campinas, 2003. Anais. Campinas: CBNA, 2003. p.255-284.

VISEK, W.J. The mode of growth promotion by antibiotics. Journal of Animal Science, v.46, p.14471469, 1978.

WANG, R.; LI, D.; BOURNE, S. Can 2000 years of herbal medicine history help us solve problems in year 2000?. In: ALLTECH'S ANNUAL SYMPOSIUM, 14., Nottingham, UK, 1998. Anais. Nottingham: ALLTECH, 1998. p.168-184.

WHITE, L. A.; NEWMAN, M. C.; CROMWELL, G. L.; LINDEMANN, M. D. Efficacy of brewers dried yeast as a source of mannanoligosaccharides, without and with organic acids, and of carbadox on performance and intestinal bacterial populations of weanling pigs. Journal of Animal Science, v.79, suppl. 1, p.305, 2001.

WILLIAMS, N.H.; STAHLY, T.S.; ZIMMERMAN, D.S. Effect of chronic immune system activation on the rate, efficiency, and composition of growth and lysine needs of pigs fed from 6-27 kg. Journal of Animal Sience, v.75, p.1463-2471, 1997a.

WILLIAMS, N.H. STAHLY, T.S.; ZIMMERMAN, D.R. Effect of level of chronic immune system activation on the growth and dietary lysine needs of pigs fed from 6 to $112 \mathrm{~kg}$. Journal of Animal Science, v.75, p.2481-2496, 1997b.

YOKOKURA, T.; YAJIMA, T.; HASHIMOTO, S. Effect of organic acid on gastrointestinal mobility pf rat in vitro. Life Sciences, v.21, p.59-62, 1977.

ZEBROWSKA, T.; LOW, A.G.; ZEBROWSKA, H. Studies on gastric digestion of protein and carbohydrate, gastric secretion and exocrine pancreatic secretion in the growing pig. British Journal of Nutrition, v.49, p.401-410, 1983. 
ZUCCHI, O.L.A.D.; NASCIMENTO FILHO, V.F. Caracterização qualitativa e quantitativa de elementos, pela técnica de fluorescência de raios X, em suplementos minerais para animais. I. Dispersão de comprimento de onda. Pesquisa Agropecuária Brasileira, v.30, p.1427-1439, 1995. 


\section{APÊNDICES}


APÊNDICE 1. Valores de matéria seca (\%), energia bruta (kcal/kg), proteína bruta (\%) e cromo (\%) das amostras de fezes e dietas

\begin{tabular}{|c|c|c|c|c|}
\hline Amostra & $\begin{array}{c}\text { Matéria seca } \\
\text { (\%) }\end{array}$ & $\begin{array}{l}\text { Energia bruta }{ }^{2} \\
\quad(\mathrm{kcal} / \mathrm{g})\end{array}$ & $\begin{array}{c}\text { Proteína bruta }{ }^{2} \\
\text { (\%) }\end{array}$ & $\begin{array}{c}\text { Cromo }^{2} \\
(\%)\end{array}$ \\
\hline Ração $^{1}$ C & 82,29 & 4053 & 29,97 & 0,107 \\
\hline Ração ${ }^{1}$ A & 82,05 & 3878 & 29,24 & 0,080 \\
\hline Ração $^{1}$ PO & 85,25 & 3714 & 27,33 & 0,106 \\
\hline Ração $^{1}$ PE & 88,29 & 3649 & 25,26 & 0,091 \\
\hline Raçãó E & 87,48 & 3663 & 25,49 & 0,091 \\
\hline Fezes C1 & 27,58 & 4902 & 31,77 & 0,432 \\
\hline Fezes C2 & 29,36 & 4443 & 29,34 & 0,460 \\
\hline Fezes C3 & 27,78 & 4533 & 30,31 & 0,410 \\
\hline Fezes C4 & 26,45 & 4513 & 32,75 & 0,483 \\
\hline Fezes A1 & 29,07 & 4485 & 26,80 & 0,487 \\
\hline Fezes A2 & 28,25 & 4299 & 39,62 & 0,485 \\
\hline Fezes A3 & 24,84 & 4423 & 31,96 & 0,467 \\
\hline Fezes A4 & 28,62 & 4338 & 31,09 & 0,421 \\
\hline Fezes PO1 & 25,11 & 4738 & 33,01 & 0,414 \\
\hline Fezes PO2 & 30,60 & 4583 & 30,95 & 0,471 \\
\hline Fezes PO3 & 27,35 & 4684 & 31,76 & 0,406 \\
\hline Fezes PO4 & 24,07 & 4581 & 33,06 & 0,410 \\
\hline Fezes PE1 & 26,04 & 4433 & 33,25 & 0,358 \\
\hline Fezes PE2 & 30,25 & 4701 & 34,41 & 0,385 \\
\hline Fezes PE3 & 25,66 & 4743 & 34,04 & 0,390 \\
\hline Fezes PE4 & 25,21 & 4746 & 32,40 & 0,412 \\
\hline Fezes E1 & 26,40 & 4479 & 29,18 & 0,544 \\
\hline Fezes E2 & 27,07 & 4692 & 34,29 & 0,435 \\
\hline Fezes E3 & 27,83 & 4631 & 30,66 & 0,426 \\
\hline Fezes E4 & 28,02 & 4577 & 32,22 & 0,427 \\
\hline
\end{tabular}

${ }^{1}$ Ração inicial com $0,1 \%$ de cromo.

${ }^{2}$ Valores expressos com base na matéria seca.

$\mathrm{C}=$ controle; $\mathrm{A}=$ antimicrobiano; $\mathrm{PO}=$ probiótico; $\mathrm{PE}=$ prebiótico; e $\mathrm{E}=$ extrato vegetal. 
APÊNDICE 2. Médias dos pesos absolutos (g) dos órgãos digestórios dos animais abatidos ao final do Experimento I

\begin{tabular}{ccccccccc}
\hline Tratamento & Repetição & $\begin{array}{c}\text { TGI } \\
\text { total } \\
\text { (g) }\end{array}$ & $\begin{array}{c}\text { Estômago } \\
\text { vazio } \\
\text { (g) }\end{array}$ & $\begin{array}{c}\text { Pâncreas } \\
\text { (g) }\end{array}$ & $\begin{array}{c}\text { Fígado } \\
\text { (g) }\end{array}$ & $\begin{array}{c}\text { Vesícula } \\
\text { biliar } \\
\text { (g) }\end{array}$ & $\begin{array}{c}\text { Intestino } \\
\text { delgado } \\
\text { vazio } \\
\text { (g) }\end{array}$ & $\begin{array}{c}\text { Intestino } \\
\text { grosso } \\
\text { vazio } \\
\text { (g) }\end{array}$ \\
\hline C & 1 & 4435 & 144 & 19 & 502 & 18 & 1003 & 386 \\
C & 2 & 4690 & 139 & 46 & 576 & 10 & 1025 & 563 \\
C & 3 & 4385 & 164 & 55 & 620 & 9 & 1020 & 458 \\
C & 4 & 3745 & 121 & 36 & 476 & 6 & 750 & 401 \\
A & 1 & 4150 & 149 & 34 & 594 & 17 & 820 & 401 \\
A & 2 & 4065 & 137 & 48 & 576 & 4 & 810 & 407 \\
A & 3 & 4740 & 177 & 61 & 715 & 11 & 1035 & 525 \\
A & 4 & 5305 & 151 & 45 & 740 & 9 & 1035 & 484 \\
PO & 1 & 4630 & 156 & 18 & 634 & 13 & 1118 & 506 \\
PO & 2 & 3550 & 113 & 33 & 523 & 13 & 895 & 441 \\
PO & 3 & 4010 & 136 & 24 & 565 & 18 & 820 & 407 \\
PO & 4 & 3870 & 120 & 38 & 520 & 18 & 830 & 328 \\
PE & 1 & 3925 & 129 & 24 & 550 & 12 & 1030 & 339 \\
PE & 2 & 3845 & 163 & 43 & 520 & 8 & 840 & 386 \\
PE & 3 & 4290 & 154 & 29 & 590 & 14 & 870 & 547 \\
PE & 4 & 3795 & 160 & 34 & 539 & 10 & 875 & 376 \\
E & 1 & 3420 & 140 & 40 & 430 & 16 & 710 & 320 \\
E & 2 & 4000 & 131 & 54 & 520 & 6 & 805 & 410 \\
E & 3 & 3900 & 111 & 36 & 542 & 4 & 820 & 443 \\
E & 4 & 4080 & 146 & 40 & 612 & 11 & 880 & 450 \\
\hline
\end{tabular}

${ }^{1}$ TGI $=$ Trato gastrintestinal.

$\mathrm{C}=$ controle; $\mathrm{A}=$ antimicrobiano; $\mathrm{PO}=$ probiótico; $\mathrm{PE}=$ prebiótico; e $\mathrm{E}=$ extrato vegetal. 
APÊNDICE 3. Médias dos pesos absolutos (g) dos órgãos digestórios e não digestórios, assim como do comprimento e da relação peso:comprimento do intestino delgado, dos animais abatidos ao final do Experimento I

\begin{tabular}{cccccccccc}
\hline Tratamento & Repetição & $\begin{array}{c}\text { Ceco } \\
\text { vazio } \\
\text { (g) }\end{array}$ & $\begin{array}{c}\text { Colo } \\
\text { vazio } \\
(\mathrm{g})\end{array}$ & $\begin{array}{c}\text { Pulmão } \\
(\mathrm{g})\end{array}$ & $\begin{array}{c}\text { Coração } \\
(\mathrm{g})\end{array}$ & $\begin{array}{c}\text { Rins } \\
(\mathrm{g})\end{array}$ & $\begin{array}{c}\text { Baço } \\
(\mathrm{g})\end{array}$ & $\begin{array}{c}\text { Comp } \\
(\mathrm{m})\end{array}$ & $\begin{array}{c}\text { Relação } \\
\text { peso/comp } \\
(\mathrm{g} / \mathrm{m})^{2}\end{array}$ \\
\hline C & 1 & 47 & 339 & 240 & 112 & 122 & 56 & 13,40 & 74,85 \\
C & 2 & 33 & 530 & 305 & 114 & 115 & 37 & 15,00 & 68,33 \\
C & 3 & 48 & 410 & 273 & 118 & 127 & 44 & 12,00 & 85,00 \\
C & 4 & 21 & 380 & 250 & 77 & 93 & 25 & 11,80 & 63,56 \\
A & 1 & 30 & 371 & 298 & 128 & 165 & 50 & 12,30 & 66,66 \\
A & 2 & 37 & 370 & 298 & 110 & 136 & 41 & 10,30 & 78,64 \\
A & 3 & 35 & 490 & 280 & 132 & 139 & 50 & 14,25 & 72,37 \\
A & 4 & 34 & 450 & 535 & 156 & 162 & 47 & 13,76 & 75,00 \\
PO & 1 & 43 & 463 & 284 & 121 & 155 & 40 & 14,00 & 79,85 \\
PO & 2 & 31 & 410 & 240 & 74 & 98 & 26 & 11,50 & 77,82 \\
PO & 3 & 32 & 375 & 340 & 90 & 101 & 33 & 12,20 & 67,21 \\
PO & 4 & 38 & 290 & 275 & 97 & 101 & 28 & 12,50 & 66,40 \\
PE & 1 & 25 & 314 & 235 & 100 & 99 & 42 & 13,70 & 75,18 \\
PE & 2 & 31 & 355 & 301 & 108 & 105 & 33 & 12,00 & 70,00 \\
PE & 3 & 27 & 520 & 208 & 90 & 105 & 29 & 13,10 & 66,41 \\
PE & 4 & 31 & 345 & 266 & 100 & 106 & 44 & 12,30 & 71,13 \\
E & 1 & 25 & 295 & 255 & 94 & 114 & 33 & 10,80 & 65,74 \\
E & 2 & 30 & 380 & 300 & 71 & 100 & 26 & 11,30 & 71,24 \\
E & 3 & 28 & 415 & 294 & 115 & 105 & 30 & 13,00 & 63,07 \\
E & 4 & 45 & 405 & 242 & 100 & 105 & 32 & 12,35 & 70,96 \\
\hline C & 3 & & & & & & &
\end{tabular}

${ }^{1}$ Comprimento do intestino delgado.

${ }^{2}$ Relação peso/comprimento do intestino delgado.

$\mathrm{C}=$ controle; $\mathrm{A}=$ antimicrobiano; $\mathrm{PO}=$ probiótico; $\mathrm{PE}=$ prebiótico; e $\mathrm{E}=$ extrato vegetal. 
APÊNDICE 4. Médias dos pesos relativos (percentagem do peso vivo) dos órgãos digestórios dos animais abatidos ao final do Experimento I

\begin{tabular}{|c|c|c|c|c|c|c|c|c|}
\hline Tratamento & Repetição & $\begin{array}{l}\text { TGI }^{1} \\
\text { total } \\
(\%)\end{array}$ & $\begin{array}{c}\text { Estômago } \\
\text { vazio } \\
\text { (\%) }\end{array}$ & $\begin{array}{c}\text { Pâncreas } \\
\text { (\%) }\end{array}$ & $\begin{array}{l}\text { Fígado } \\
(\%)\end{array}$ & $\begin{array}{c}\text { Vesícula } \\
\text { biliar } \\
\text { (\%) }\end{array}$ & $\begin{array}{c}\text { Intestino } \\
\text { delgado } \\
\text { vazio } \\
(\%)\end{array}$ & $\begin{array}{c}\text { Intestino } \\
\text { grosso } \\
\text { vazio } \\
(\%)\end{array}$ \\
\hline $\mathrm{C}$ & 1 & 22,628 & 0,735 & 0,097 & 2,561 & 0,092 & 5,117 & 1,969 \\
\hline $\mathrm{C}$ & 2 & 24,301 & 0,720 & 0,238 & 2,984 & 0,052 & 5,311 & 2,917 \\
\hline C & 3 & 20,301 & 0,759 & 0,255 & 2,870 & 0,042 & 4,722 & 2,120 \\
\hline C & 4 & 24,161 & 0,781 & 0,232 & 3,071 & 0,039 & 4,839 & 2,587 \\
\hline A & 1 & 19,762 & 0,710 & 0,162 & 2,829 & 0,081 & 3,905 & 1,910 \\
\hline A & 2 & 21,395 & 0,721 & 0,253 & 3,032 & 0,021 & 4,263 & 2,142 \\
\hline A & 3 & 20,519 & 0,766 & 0,264 & 3,095 & 0,048 & 4,481 & 2,273 \\
\hline A & 4 & 22,104 & 0,629 & 0,188 & 3,083 & 0,038 & 4,313 & 2,017 \\
\hline PO & 1 & 18,016 & 0,607 & 0,070 & 2,467 & 0,051 & 4,350 & 1,969 \\
\hline PO & 2 & 21,131 & 0,673 & 0,196 & 3,113 & 0,077 & 5,327 & 2,625 \\
\hline $\mathrm{PO}$ & 3 & 23,588 & 0,800 & 0,141 & 3,324 & 0,106 & 4,824 & 2,394 \\
\hline PO & 4 & 21,620 & 0,670 & 0,212 & 2,905 & 0,101 & 4,637 & 1,832 \\
\hline $\mathrm{PE}$ & 1 & 19,625 & 0,645 & 0,120 & 2,750 & 0,060 & 5,150 & 1,695 \\
\hline $\mathrm{PE}$ & 2 & 18,486 & 0,784 & 0,207 & 2,500 & 0,038 & 4,038 & 1,856 \\
\hline $\mathrm{PE}$ & 3 & 21,101 & 0,865 & 0,163 & 3,315 & 0,079 & 4,888 & 3,073 \\
\hline $\mathrm{PE}$ & 4 & 18,787 & 0,792 & 0,168 & 2,668 & 0,050 & 4,332 & 1,861 \\
\hline $\mathrm{E}$ & 1 & 19,000 & 0,778 & 0,222 & 2,389 & 0,089 & 3,944 & 1,778 \\
\hline E & 2 & 27,397 & 0,897 & 0,370 & 3,562 & 0,041 & 5,514 & 2,808 \\
\hline $\mathrm{E}$ & 3 & 21,311 & 0,607 & 0,197 & 2,962 & 0,022 & 4,481 & 2,421 \\
\hline E & 4 & 21,935 & 0,785 & 0,215 & 3,290 & 0,055 & 4,731 & 2,419 \\
\hline
\end{tabular}

${ }^{1}$ TGI= Trato gastrintestinal.

$\mathrm{C}=$ controle; $\mathrm{A}=$ antimicrobiano; $\mathrm{PO}=$ probiótico; $\mathrm{PE}=$ prebiótico; e $\mathrm{E}=$ =xtrato vegetal. 
APÊNDICE 5. Médias dos pesos relativos (percentagem do peso vivo) dos órgãos digestórios e não digestórios, assim como do comprimento relativo do intestino delgado, dos animais abatidos ao final do Experimento I

\begin{tabular}{ccccccccc}
\hline Tratamento & Repetição & $\begin{array}{c}\text { Ceco } \\
\text { vazio } \\
(\%)\end{array}$ & $\begin{array}{c}\text { Colo } \\
\text { vazio } \\
(\%)\end{array}$ & $\begin{array}{c}\text { Pulmão } \\
(\%)\end{array}$ & $\begin{array}{c}\text { Coração } \\
(\%)\end{array}$ & $\begin{array}{c}\text { Rins } \\
(\%)\end{array}$ & $\begin{array}{c}\text { Comprimento } \\
\text { relativo do ID } \\
\text { (m/kg de PV) }\end{array}$ & $\begin{array}{c}\text { Baço } \\
(\%)\end{array}$ \\
\hline C & 1 & 0,240 & 1,730 & 1,224 & 0,571 & 0,622 & 0,684 & 0,286 \\
C & 2 & 0,171 & 2,746 & 1,580 & 0,591 & 0,596 & 0,777 & 0,192 \\
C & 3 & 0,222 & 1,898 & 1,264 & 0,546 & 0,588 &, 556 & 0,204 \\
C & 4 & 0,135 & 2,452 & 1,613 & 0,497 & 0,600 & 0,761 & 0,161 \\
A & 1 & 0,143 & 1,767 & 1,419 & 0,610 & 0,786 & 0,586 & 0,238 \\
A & 2 & 0,195 & 1,947 & 1,568 & 0,579 & 0,716 & 0,542 & 0,216 \\
A & 3 & 0,152 & 2,121 & 1,212 & 0,571 & 0,602 & 0,619 & 0,216 \\
A & 4 & 0,142 & 1,875 & 2,229 & 0,650 & 0,675 & 0,575 & 0,196 \\
PO & 1 & 0,167 & 1,802 & 1,105 & 0,471 & 0,603 & 0,545 & 0,156 \\
PO & 2 & 0,185 & 2,440 & 1,429 & 0,440 & 0,583 & 0,685 & 0,155 \\
PO & 3 & 0,188 & 2,206 & 2,000 & 0,529 & 0,594 & 0,718 & 0,194 \\
PO & 4 & 0,212 & 1,620 & 1,536 & 0,542 & 0,564 & 0,698 & 0,156 \\
PE & 1 & 0,125 & 1,570 & 1,175 & 0,500 & 0,495 & 0,685 & 0,210 \\
PE & 2 & 0,149 & 1,707 & 1,447 & 0,519 & 0,505 & 0,577 & 0,159 \\
PE & 3 & 0,152 & 2,921 & 1,169 & 0,506 & 0,590 & 0,736 & 0,163 \\
PE & 4 & 0,153 & 1,708 & 1,317 & 0,495 & 0,525 & 0,609 & 0,218 \\
E & 1 & 0,139 & 1,639 & 1,417 & 0,522 & 0,633 & 0,600 & 0,183 \\
E & 2 & 0,205 & 2,603 & 2,055 & 0,486 & 0,685 & 0,774 & 0,178 \\
E & 3 & 0,153 & 2,268 & 1,607 & 0,628 & 0,574 & 0,710 & 0,164 \\
E & 4 & 0,242 & 2,177 & 1,301 & 0,538 & 0,565 & 0,667 & 0,172 \\
\hline Con
\end{tabular}

${ }^{1}$ Comprimento relativo do intestino delgado ( $\mathrm{m} / \mathrm{kg}$ de peso vivo).

$\mathrm{C}=$ controle; $\mathrm{A}=$ antimicrobiano; $\mathrm{PO}=$ probiótico; $\mathrm{PE}=$ prebiótico; e $\mathrm{E}=$ extrato vegetal. 
APÊNDICE 6. Peso vivo (kg) dos animais ao $1^{\circ}, 14^{\circ}$ e $35^{\circ}$ dia do Experimento II, considerando a média da unidade experimental

\begin{tabular}{|c|c|c|c|c|c|c|c|}
\hline \multirow{2}{*}{$\begin{array}{c}\text { Dias de } \\
\text { experimento }\end{array}$} & \multirow[b]{2}{*}{ Bloco } & \multicolumn{5}{|c|}{ Tratamento } & \multirow[b]{2}{*}{ Média } \\
\hline & & C & A & $\mathrm{PO}$ & $\mathrm{PE}$ & $\mathrm{E}$ & \\
\hline \multirow{13}{*}{$\begin{array}{l}1^{\mathrm{o}} \\
\text { dia }\end{array}$} & 1 & 6,488 & 6,615 & 6,670 & 6,440 & 6,505 & 6,544 \\
\hline & 2 & 5,968 & 5,923 & 6,000 & 5,980 & 5,968 & 5,968 \\
\hline & 3 & 5,630 & 5,640 & 5,695 & 5,660 & 5,695 & 5,664 \\
\hline & 4 & 5,270 & 5,343 & 5,310 & 5,343 & 5,308 & 5,315 \\
\hline & 5 & 6,830 & 6,820 & 6,910 & 6,820 & 6,880 & 6,852 \\
\hline & 6 & 6,380 & 6,360 & 6,310 & 6,340 & 6,360 & 6,350 \\
\hline & 7 & 5,990 & 6,020 & 6,010 & 5,980 & 5,990 & 5,998 \\
\hline & 8 & 5,690 & 5,660 & 5,670 & 5,670 & 5,750 & 5,688 \\
\hline & 9 & 6,610 & 6,580 & 6,580 & 6,640 & 6,640 & 6,610 \\
\hline & 10 & 6,190 & 6,210 & 6,140 & 6,190 & 6,160 & 6,178 \\
\hline & 11 & 5,870 & 5,880 & 5,860 & 5,930 & 5,890 & 5,886 \\
\hline & -12 & 5,480 & $5, \underline{4} 10$ & $-5,420$ & 5,480 & $-5,440$ & 5,446 \\
\hline & Média & 6,033 & 6,038 & 6,048 & 6,039 & 6,049 & 6,042 \\
\hline \multirow{13}{*}{$\begin{array}{l}14^{\circ} \\
\text { dia }\end{array}$} & 1 & 7,608 & 8,113 & 8,005 & 9,950 & 8,200 & 8,375 \\
\hline & 2 & 8,068 & 8,020 & 6,958 & 9,160 & 6,023 & 7,646 \\
\hline & 3 & 7,730 & 9,338 & 8,158 & 7,205 & 7,385 & 7,963 \\
\hline & 4 & 6,965 & 9,673 & 7,340 & 7,938 & 7,578 & 7,899 \\
\hline & 5 & 9,110 & 10,500 & 7,420 & 10,600 & 9,700 & 9,466 \\
\hline & 6 & 9,340 & 8,160 & 9,470 & 9,380 & 7,680 & 8,806 \\
\hline & 7 & 8,690 & 10,440 & 7,310 & 9,120 & 7,230 & 8,558 \\
\hline & 8 & 8,040 & 6,710 & 8,120 & 7,120 & 7,270 & 7,452 \\
\hline & 9 & 9,680 & 8,570 & 8,570 & 9,270 & 7,800 & 8,778 \\
\hline & 10 & 8,990 & 9,290 & 7,840 & 9,840 & 9,310 & 9,054 \\
\hline & 11 & 8,550 & 9,020 & 8,880 & 8,230 & 8,650 & 8,666 \\
\hline & - 12 & 7,080 & 7,500. & $8,4 \underline{0}$ & 9,200 & $\begin{array}{r}7,850 \\
-\end{array}$ & - \\
\hline & Média & 8,321 & 8,778 & 8,043 & 8,918 & 7,890 & 8,390 \\
\hline \multirow{13}{*}{$\begin{array}{l}35^{\circ} \\
\text { dia }\end{array}$} & 1 & 17,800 & 20,650 & 19,100 & 20,000 & 18,000 & 19,110 \\
\hline & 2 & 17,500 & 18,900 & 14,950 & 19,400 & 12,700 & 16,690 \\
\hline & 3 & 17,150 & 21,650 & 16,950 & 15,100 & 16,950 & 17,560 \\
\hline & 4 & 15,200 & 22,950 & 17,000 & 19,150 & 17,850 & 18,430 \\
\hline & 5 & 22,320 & 24,640 & 13,090 & 25,850 & 21,610 & 21,502 \\
\hline & 6 & 18,610 & 23,180 & 21,260 & 19,620 & 17,660 & 20,066 \\
\hline & 7 & 18,200 & 25,370 & 16,990 & 24,130 & 18,880 & 20,714 \\
\hline & 8 & 20,210 & 16,720 & 21,670 & 18,040 & 18,530 & 19,034 \\
\hline & 9 & 22,680 & 23,590 & 19,180 & 22,840 & 18,280 & 21,314 \\
\hline & 10 & 21,740 & 23,880 & 20,410 & 23,750 & 22,360 & 22,428 \\
\hline & 11 & 20,570 & 21,900 & 20,540 & 20,630 & 21,280 & 20,984 \\
\hline & -12 & 17,100 & $-19,610$. & 20,910 & -21,680 & 17,540 & - \\
\hline & Média & 19,090 & 21,920 & 18,504 & 20,849 & 18,470 & 19,767 \\
\hline
\end{tabular}

$\mathrm{C}=$ controle; $\mathrm{A}=$ antimicrobiano; $\mathrm{PO}=$ probiótico; $\mathrm{PE}=$ prebiótico; e $\mathrm{E}=$ extrato vegetal. 
APÊNDICE 7. Consumo diário de ração por leitão $(\mathrm{kg})$ nos períodos de um a 14, 15 a 35 e um a 35 dias do Experimento II, considerando a média da unidade experimental

\begin{tabular}{|c|c|c|c|c|c|c|c|}
\hline \multirow{2}{*}{$\begin{array}{c}\text { Dias de } \\
\text { experimento }\end{array}$} & \multirow[b]{2}{*}{ Bloco } & \multicolumn{5}{|c|}{ Tratamento } & \multirow[b]{2}{*}{ Média } \\
\hline & & C & A & $\mathrm{PO}$ & PE & E & \\
\hline \multirow{13}{*}{$\begin{array}{l}1-14 \\
\text { dias }\end{array}$} & 1 & 0,244 & 0,256 & 0,196 & 0,313 & 0,238 & 0,249 \\
\hline & 2 & 0,220 & 0,210 & 0,178 & 0,320 & 0,182 & 0,222 \\
\hline & 3 & 0,213 & 0,326 & 0,355 & 0,225 & 0,208 & 0,265 \\
\hline & 4 & 0,213 & 0,372 & 0,251 & 0,282 & 0,275 & 0,279 \\
\hline & 5 & 0,298 & 0,350 & 0,170 & 0,379 & 0,281 & 0,296 \\
\hline & 6 & 0,343 & 0,273 & 0,312 & 0,297 & 0,210 & 0,287 \\
\hline & 7 & 0,260 & 0,394 & 0,202 & 0,290 & 0,230 & 0,275 \\
\hline & 8 & 0,292 & 0,200 & 0,273 & 0,229 & 0,263 & 0,251 \\
\hline & 9 & 0,332 & 0,300 & 0,277 & 0,297 & 0,224 & 0,286 \\
\hline & 10 & 0,328 & 0,373 & 0,272 & 0,376 & 0,341 & 0,338 \\
\hline & 11 & 0,322 & 0,328 & 0,298 & 0,290 & 0,312 & 0,310 \\
\hline & $\ldots-12$ & 0,271 & $\underline{0}, \underline{2} \mathbf{7}$ & $\underline{0}, \underline{3} 44$ & 0,371 & 0,261 & $\underline{0}, \underline{3} 0{ }^{-}$ \\
\hline & Média & 0.278 & 0.305 & 0.261 & 0.306 & 0.252 & 0.280 \\
\hline \multirow{13}{*}{$\begin{array}{c}\text { 14-35 } \\
\text { dias }\end{array}$} & 1 & 0,735 & 0,871 & 0,740 & 0,798 & 0,645 & 0,758 \\
\hline & 2 & 0,690 & 0,730 & 0,532 & 0,839 & 0,468 & 0,652 \\
\hline & 3 & 0,573 & 0,851 & 0,660 & 0,553 & 0,630 & 0,653 \\
\hline & 4 & 0,711 & 0,832 & 0,753 & 0,709 & 0,744 & 0,750 \\
\hline & 5 & 0,976 & 1,066 & 0,388 & 1,139 & 0,846 & 0,883 \\
\hline & 6 & 0,701 & 1,090 & 0,877 & 0,826 & 0,711 & 0,841 \\
\hline & 7 & 0,783 & 1,104 & 0,694 & 1,027 & 0,748 & 0,871 \\
\hline & 8 & 0,871 & 0,713 & 0,939 & 0,731 & 0,783 & 0,807 \\
\hline & 9 & 1,130 & 1,153 & 0,822 & 0,974 & 0,827 & 0,981 \\
\hline & 10 & 1,005 & 1,098 & 0,883 & 1,030 & 0,927 & 0,989 \\
\hline & 11 & 0,943 & 0,970 & 0,696 & 1,007 & 0,934 & 0,910 \\
\hline & _ & $0,69 \underline{4}$ & $\underline{0}, \underline{9} 5 \underline{3}$ & $\underline{0}, \underline{9} \underline{12}$ & $0, \underline{9} 6 \underline{3}$ & 0,708 & $\underline{0}, \underline{8} \underline{B}_{-}$ \\
\hline & Média & 0.818 & 0.953 & 0.741 & 0.883 & 0.748 & 0.828 \\
\hline \multirow{13}{*}{$\begin{array}{l}1-35 \\
\text { dias }\end{array}$} & 1 & 0,539 & 0,625 & 0,522 & 0,604 & 0,482 & 0,554 \\
\hline & 2 & 0,502 & 0,522 & 0,390 & 0,631 & 0,354 & 0,480 \\
\hline & 3 & 0,429 & 0,641 & 0,538 & 0,422 & 0,461 & 0,498 \\
\hline & 4 & 0,512 & 0,648 & 0,552 & 0,538 & 0,556 & 0,561 \\
\hline & 5 & 0,705 & 0,779 & 0,301 & 0,835 & 0,620 & 0,648 \\
\hline & 6 & 0,558 & 0,763 & 0,651 & 0,615 & 0,511 & 0,620 \\
\hline & 7 & 0,574 & 0,820 & 0,498 & 0,733 & 0,541 & 0,633 \\
\hline & 8 & 0,640 & 0,508 & 0,672 & 0,530 & 0,575 & 0,585 \\
\hline & 9 & 0,811 & 0,812 & 0,604 & 0,703 & 0,586 & 0,703 \\
\hline & 10 & 0,734 & 0,808 & 0,638 & 0,768 & 0,692 & 0,728 \\
\hline & 11 & 0,695 & 0,713 & 0,537 & 0,720 & 0,586 & 0,650 \\
\hline & . $\ldots$ & $0, \underline{5} 2 \underline{5}$ & $\underline{0}, \underline{6} 83$ & $\underline{0}, \underline{6} \mathbf{8} 5$ & 0,726 & $-0,52 \underline{9}$ & - \\
\hline & Média & 0,602 & 0,694 & 0,549 & 0,652 & 0,541 & 0,608 \\
\hline
\end{tabular}

$\mathrm{C}=$ controle; $\mathrm{A}=$ antimicrobiano; $\mathrm{PO}=$ probiótico; $\mathrm{PE}=$ prebiótico; e $\mathrm{E}=\mathrm{O}$ extrato vegetal. 
APÊNDICE 8. Ganho diário de peso por leitão (kg) nos períodos de um a 14, 15 a 35 e um a 35 dias do Experimento II, considerando a média da unidade experimental

\begin{tabular}{|c|c|c|c|c|c|c|c|}
\hline \multirow{2}{*}{$\begin{array}{c}\text { Dias de } \\
\text { experimento }\end{array}$} & \multirow[b]{2}{*}{ Bloco } & \multicolumn{5}{|c|}{ Tratamento } & \multirow[b]{2}{*}{ Média } \\
\hline & & C & A & $\mathrm{PO}$ & $\mathrm{PE}$ & $\mathrm{E}$ & \\
\hline \multirow{13}{*}{$\begin{array}{l}1-14 \\
\text { dias }\end{array}$} & 1 & 0,080 & 0,107 & 0,095 & 0,251 & 0,121 & 0,131 \\
\hline & 2 & 0,150 & 0,150 & 0,068 & 0,227 & 0,004 & 0,120 \\
\hline & 3 & 0,150 & 0,264 & 0,176 & 0,110 & 0,121 & 0,164 \\
\hline & 4 & 0,121 & 0,309 & 0,145 & 0,185 & 0,162 & 0,184 \\
\hline & 5 & 0,163 & 0,263 & 0,036 & 0,270 & 0,201 & 0,187 \\
\hline & 6 & 0,211 & 0,129 & 0,226 & 0,217 & 0,094 & 0,175 \\
\hline & 7 & 0,193 & 0,316 & 0,093 & 0,224 & 0,089 & 0,183 \\
\hline & 8 & 0,168 & 0,075 & 0,175 & 0,104 & 0,109 & 0,126 \\
\hline & 9 & 0,219 & 0,142 & 0,142 & 0,188 & 0,083 & 0,155 \\
\hline & 10 & 0,200 & 0,220 & 0,121 & 0,261 & 0,225 & 0,205 \\
\hline & 11 & 0,191 & 0,224 & 0,216 & 0,164 & 0,197 & 0,198 \\
\hline & . . . & $\underline{0}, \underline{1} 14$ & 0,149 & 0,216 & $0,26 \underline{6}$ & 0,172 & $\underline{0}, \underline{1} \mathbf{1}_{3} \ldots$ \\
\hline & Média & 0,163 & 0,196 & 0,142 & 0,206 & 0,132 & 0,168 \\
\hline \multirow{13}{*}{$\begin{array}{c}\text { 14-35 } \\
\text { dias }\end{array}$} & 1 & 0,485 & 0,597 & 0,528 & 0,479 & 0,467 & 0,511 \\
\hline & 2 & 0,449 & 0,518 & 0,381 & 0,488 & 0,318 & 0,431 \\
\hline & 3 & 0,449 & 0,586 & 0,419 & 0,376 & 0,455 & 0,457 \\
\hline & 4 & 0,392 & 0,632 & 0,460 & 0,534 & 0,489 & 0,501 \\
\hline & 5 & 0,629 & 0,673 & 0,270 & 0,726 & 0,567 & 0,573 \\
\hline & 6 & 0,441 & 0,715 & 0,561 & 0,488 & 0,475 & 0,536 \\
\hline & 7 & 0,453 & 0,711 & 0,461 & 0,715 & 0,555 & 0,579 \\
\hline & 8 & 0,580 & 0,477 & 0,645 & 0,520 & 0,536 & 0,552 \\
\hline & 9 & 0,619 & 0,715 & 0,505 & 0,646 & 0,499 & 0,597 \\
\hline & 10 & 0,607 & 0,695 & 0,599 & 0,662 & 0,621 & 0,637 \\
\hline & 11 & 0,572 & 0,613 & 0,555 & 0,590 & 0,601 & 0,586 \\
\hline & _ _ _ & $\underline{0}, \underline{4} 7$ & $0,577$. & $0,59 \underline{3}$ & $-0,59 \underline{4}$ & 0,461 & $\underline{0}, \underline{5} 40$ \\
\hline & Média & 0,513 & 0,626 & 0,498 & 0,568 & 0,504 & 0,542 \\
\hline \multirow{13}{*}{$\begin{array}{l}1-35 \\
\text { dias }\end{array}$} & 1 & 0,323 & 0,401 & 0,355 & 0,387 & 0,328 & 0,359 \\
\hline & 2 & 0,330 & 0,371 & 0,256 & 0,383 & 0,192 & 0,306 \\
\hline & 3 & 0,329 & 0,457 & 0,322 & 0,270 & 0,322 & 0,340 \\
\hline & 4 & 0,284 & 0,503 & 0,334 & 0,395 & 0,358 & 0,375 \\
\hline & 5 & 0,443 & 0,509 & 0,177 & 0,544 & 0,421 & 0,419 \\
\hline & 6 & 0,349 & 0,481 & 0,427 & 0,379 & 0,323 & 0,392 \\
\hline & 7 & 0,349 & 0,553 & 0,314 & 0,519 & 0,368 & 0,421 \\
\hline & 8 & 0,415 & 0,316 & 0,457 & 0,353 & 0,365 & 0,381 \\
\hline & 9 & 0,459 & 0,486 & 0,360 & 0,463 & 0,333 & 0,420 \\
\hline & 10 & 0,444 & 0,505 & 0,408 & 0,502 & 0,463 & 0,464 \\
\hline & 11 & 0,420 & 0,458 & 0,419 & 0,420 & 0,440 & 0,431 \\
\hline & - 12 & 0,332. & $0, \underline{4} 06$ & $-0,443$ & $-0,463$ & 0,346 & - \\
\hline & Média & 0,373 & 0,454 & 0,356 & 0,423 & 0,355 & 0,392 \\
\hline
\end{tabular}


APÊNDICE 9. Conversão alimentar nos períodos de um a 14, 15 a 35 e um a 35 dias do Experimento II, considerando a média da unidade experimental

\begin{tabular}{|c|c|c|c|c|c|c|c|}
\hline \multirow{2}{*}{$\begin{array}{c}\text { Dias de } \\
\text { experimento }\end{array}$} & \multirow[b]{2}{*}{ Bloco } & \multicolumn{5}{|c|}{ Tratamento } & \multirow[b]{2}{*}{ Média } \\
\hline & & C & A & $\mathrm{PO}$ & $\mathrm{PE}$ & $\mathrm{E}$ & \\
\hline \multirow{13}{*}{$\begin{array}{l}1-14 \\
\text { dias }\end{array}$} & 1 & 3,049 & 2,396 & 2,052 & 1,248 & 1,962 & 2,141 \\
\hline & 2 & 1,464 & 1,404 & 2,598 & 1,407 & $46,318 *$ & 1,718 \\
\hline & 3 & 1,417 & 1,235 & 2,017 & 2,036 & 1,719 & 1,685 \\
\hline & 4 & 1,761 & 1,202 & 1,730 & 1,521 & 1,696 & 1,582 \\
\hline & 5 & 1,828 & 1,330 & 4,167 & 1,404 & 1,393 & 2,024 \\
\hline & 6 & 1,621 & 2,119 & 1,383 & 1,368 & 2,231 & 1,744 \\
\hline & 7 & 1,349 & 1,247 & 2,177 & 1,295 & 2,597 & 1,733 \\
\hline & 8 & 1,738 & 2,671 & 1,558 & 2,210 & 2,421 & 2,120 \\
\hline & 9 & 1,515 & 2,112 & 1,946 & 1,580 & 2,703 & 1,971 \\
\hline & 10 & 1,638 & 1,696 & 2,237 & 1,442 & 1,514 & 1,705 \\
\hline & 11 & 1,684 & 1,463 & 1,382 & 1,766 & 1,583 & 1,576 \\
\hline & _ _ _ & $\underline{2}, 470$ & 1,865 & 1,592 & _1,398 & 1,515 & $1, \underline{6} 6$ \\
\hline & Média & 1,795 & 1,728 & 2,070 & 1,556 & 1,939 & 1,818 \\
\hline \multirow{13}{*}{$\begin{array}{c}\text { 14-35 } \\
\text { dias }\end{array}$} & 1 & 1,515 & 1,458 & 1,401 & 1,667 & 1,382 & 1,485 \\
\hline & 2 & 1,536 & 1,409 & 1,397 & 1,720 & 1,472 & 1,507 \\
\hline & 3 & 1,278 & 1,451 & 1,577 & 1,472 & 1,382 & 1,432 \\
\hline & 4 & 1,812 & 1,316 & 1,638 & 1,328 & 1,521 & 1,523 \\
\hline & 5 & 1,551 & 1,583 & 1,439 & 1,568 & 1,492 & 1,527 \\
\hline & 6 & 1,589 & 1,524 & 1,561 & 1,695 & 1,496 & 1,573 \\
\hline & 7 & 1,730 & 1,553 & 1,506 & 1,437 & 1,348 & 1,515 \\
\hline & 8 & 1,503 & 1,497 & 1,455 & 1,405 & 1,460 & 1,464 \\
\hline & 9 & 1,826 & 1,612 & 1,626 & 1,507 & 1,657 & 1,646 \\
\hline & 10 & 1,656 & 1,581 & 1,475 & 1,555 & 1,491 & 1,552 \\
\hline & 11 & 1,647 & 1,582 & 2,001 & 1,705 & 1,553 & 1,698 \\
\hline & _ _ _ & 1,454 & 1,652 & $-1,532$ & $1,6 \underline{6} \underline{-1}$ & $1,53{ }^{\prime}$ & $1, \underline{1} 56$ \\
\hline & Média & 1,591 & 1,518 & 1,551 & 1,555 & 1,482 & 1,540 \\
\hline \multirow{12}{*}{$\begin{array}{l}1-35 \\
\text { dias }\end{array}$} & 1 & 1,667 & 1,558 & 1,471 & 1,558 & 1,468 & 1,544 \\
\hline & 2 & 1,523 & 1,408 & 1,525 & 1,646 & 1,839 & 1,588 \\
\hline & 3 & 1,303 & 1,401 & 1,673 & 1,564 & 1,433 & 1,475 \\
\hline & 4 & 1,804 & 1,288 & 1,654 & 1,364 & 1,553 & 1,533 \\
\hline & 5 & 1,592 & 1,531 & 1,688 & 1,535 & 1,473 & 1,564 \\
\hline & 6 & 1,596 & 1,588 & 1,524 & 1,620 & 1,582 & 1,582 \\
\hline & 7 & 1,646 & 1,483 & 1,586 & 1,413 & 1,468 & 1,519 \\
\hline & 8 & 1,541 & 1,608 & 1,471 & 1,500 & 1,574 & 1,539 \\
\hline & 9 & 1,767 & 1,671 & 1,677 & 1,519 & 1,762 & 1,679 \\
\hline & 10 & 1,653 & 1,601 & 1,566 & 1,531 & 1,496 & 1,569 \\
\hline & 11 & 1,654 & 1,558 & 1,787 & 1,714 & 1,558 & 1,654 \\
\hline & - - $\frac{12}{2}-$ & $\begin{array}{l}1,621 \\
1,614\end{array}$ & $\begin{array}{r}1,683 \\
1,532\end{array}$ & $\begin{array}{r}1,548 \\
1,598\end{array}$ & $\begin{array}{c}1,528 \\
1,541\end{array}$ & $\begin{array}{c}1,530 \\
-1,561\end{array}$ & $\begin{array}{l}1,582 \\
1,569\end{array}$ \\
\hline
\end{tabular}

(*) Valor desconsiderado no cálculo das médias.

$\mathrm{C}=$ controle; $\mathrm{A}=$ antimicrobiano; $\mathrm{PO}=$ probiótico; $\mathrm{PE}=$ prebiótico; e $\mathrm{E}=$ extrato vegetal. 
APÊNDICE 10. Totais de escores fecais por bloco, no período de um a 14 dias de experimentação(Experimento II)

\begin{tabular}{|c|c|c|c|c|c|c|c|c|c|c|c|c|}
\hline \multirow[b]{2}{*}{ Escore } & \multicolumn{12}{|c|}{ Tratamento controle } \\
\hline & Bloco1 & Bloco2 & Bloco3 & Bloco4 & Bloco5 & Bloco6 & Bloco7 & Bloco8 & Bloco9 & Bloco10 & Bloco11 & Bloco12 \\
\hline $\mathbf{0}$ & 14 & 23 & 28 & 21 & 11 & 12 & 11 & 7 & 8 & 7 & 16 & 10 \\
\hline 1 & 6 & 4 & 0 & 3 & 8 & 7 & 7 & 9 & 6 & 4 & 6 & 4 \\
\hline$(0+1)$ & 20 & 27 & 28 & 24 & 19 & 19 & 18 & 16 & 14 & 11 & 22 & 14 \\
\hline 2 & 4 & 1 & 0 & 3 & 5 & 6 & 2 & 5 & 10 & 13 & 3 & 4 \\
\hline 3 & 4 & 0 & 0 & 1 & 4 & 3 & 8 & 7 & 4 & 4 & 3 & 10 \\
\hline$(2+3)$ & 8 & 1 & 0 & 4 & 9 & 9 & 10 & 12 & 14 & 17 & 6 & 14 \\
\hline \multirow[t]{2}{*}{ Total } & 28 & 28 & 28 & 28 & 28 & 28 & 28 & 28 & 28 & 28 & 28 & 28 \\
\hline & \multicolumn{12}{|c|}{ Tratamento antimicrobiano } \\
\hline Escore & Bloco1 & Bloco2 & Bloco3 & Bloco4 & Bloco5 & Bloco6 & Bloco7 & Bloco8 & Bloco9 & Bloco10 & Bloco11 & Bloco12 \\
\hline $\mathbf{0}$ & 13 & 26 & 23 & 16 & 13 & 6 & 13 & 20 & 7 & 4 & 9 & 9 \\
\hline 1 & 5 & 2 & 3 & 6 & 11 & 7 & 13 & 2 & 8 & 5 & 12 & 5 \\
\hline$(0+1)$ & 18 & 28 & 26 & 22 & 24 & 13 & 26 & 22 & 15 & 9 & 21 & 14 \\
\hline 2 & 6 & 0 & 2 & 6 & 2 & 6 & 2 & 2 & 5 & 16 & 6 & 11 \\
\hline 3 & 4 & 0 & 0 & 0 & 2 & 9 & 0 & 4 & 8 & 3 & 1 & 3 \\
\hline$(2+3)$ & 10 & 0 & 2 & 6 & 4 & 15 & 2 & 6 & 13 & 19 & 7 & 14 \\
\hline \multirow[t]{2}{*}{ Total } & 28 & 28 & 28 & 28 & 28 & 28 & 28 & 28 & 28 & 28 & 28 & 28 \\
\hline & \multicolumn{12}{|c|}{ Tratamento probiótico } \\
\hline Escore & Bloco1 & Bloco2 & Bloco3 & Bloco4 & Bloco5 & Bloco6 & Bloco7 & Bloco8 & Bloco9 & Bloco10 & Bloco11 & Bloco12 \\
\hline $\mathbf{0}$ & 21 & 15 & 6 & 11 & 21 & 10 & 11 & 5 & 8 & 4 & 10 & 5 \\
\hline 1 & 5 & 7 & 7 & 6 & 4 & 11 & 7 & 11 & 6 & 10 & 14 & 16 \\
\hline$(0+1)$ & 26 & 22 & 13 & 17 & 25 & 21 & 18 & 16 & 14 & 14 & 24 & 21 \\
\hline 2 & 2 & 5 & 5 & 5 & 2 & 7 & 6 & 10 & 6 & 9 & 4 & 6 \\
\hline 3 & 0 & 1 & 10 & 6 & 1 & 0 & 4 & 2 & 8 & 5 & 0 & 1 \\
\hline$(2+3)$ & 2 & 6 & 15 & 11 & 3 & 7 & 10 & 12 & 14 & 14 & 4 & 7 \\
\hline \multirow[t]{2}{*}{ Total } & 28 & 28 & 28 & 28 & 28 & 28 & 28 & 28 & 28 & 28 & 28 & 28 \\
\hline & \multicolumn{12}{|c|}{ Tratamento prebiótico } \\
\hline Escore & Bloco1 & Bloco2 & Bloco3 & Bloco4 & Bloco5 & Bloco6 & Bloco7 & Bloco8 & Bloco9 & Bloco10 & Bloco11 & Bloco12 \\
\hline $\mathbf{0}$ & 13 & 17 & 20 & 10 & 13 & 12 & 18 & 21 & 8 & 7 & 7 & 14 \\
\hline 1 & 11 & 10 & 6 & 10 & 9 & 15 & 8 & 1 & 13 & 11 & 5 & 7 \\
\hline$(0+1)$ & 24 & 27 & 26 & 20 & 22 & 27 & 26 & 22 & 21 & 18 & 12 & 21 \\
\hline 2 & 2 & 1 & 1 & 1 & 3 & 1 & 2 & 2 & 5 & 6 & 12 & 4 \\
\hline 3 & 2 & 0 & 1 & 7 & 3 & 0 & 0 & 4 & 2 & 4 & 4 & 3 \\
\hline$(2+3)$ & 4 & 1 & 2 & 8 & 6 & 1 & 2 & 6 & 7 & 10 & 16 & 7 \\
\hline \multirow[t]{2}{*}{ Total } & 28 & 28 & 28 & 28 & 28 & 28 & 28 & 28 & 28 & 28 & 28 & 28 \\
\hline & \multicolumn{12}{|c|}{ Tratamento extrato vegetal } \\
\hline Escore & Bloco1 & Bloco2 & Bloco3 & Bloco4 & Bloco5 & Bloco6 & Bloco7 & Bloco8 & Bloco9 & Bloco10 & Bloco11 & Bloco12 \\
\hline $\mathbf{0}$ & 22 & 10 & 21 & 19 & 19 & 10 & 9 & 20 & 9 & 9 & 12 & 19 \\
\hline 1 & 6 & 1 & 3 & 3 & 7 & 3 & 4 & 5 & 10 & 12 & 6 & 5 \\
\hline$(0+1)$ & 28 & 11 & 24 & 22 & 26 & 13 & 13 & 25 & 19 & 21 & 18 & 24 \\
\hline 2 & 0 & 5 & 1 & 0 & 2 & 10 & 8 & 2 & 3 & 5 & 7 & 2 \\
\hline 3 & 0 & 12 & 3 & 6 & 0 & 5 & 7 & 1 & 6 & 2 & 3 & 2 \\
\hline$(2+3)$ & 0 & 17 & 4 & 6 & 2 & 15 & 15 & 3 & 9 & 7 & 10 & 4 \\
\hline Total & 28 & 28 & 28 & 28 & 28 & 28 & 28 & 28 & 28 & 28 & 28 & 28 \\
\hline
\end{tabular}

Escores 0 e 1 são considerados casos normais

Escores 2 e 3 são considerados diarréia 
APÊNDICE 11. Totais de escores fecais por bloco, no período de 15 a 35 dias de experimentação (Experimento II)

\begin{tabular}{|c|c|c|c|c|c|c|c|c|c|c|c|c|}
\hline \multirow[b]{2}{*}{ Escore } & \multicolumn{12}{|c|}{ Tratamento controle } \\
\hline & Bloco1 & Bloco2 & Bloco3 & Bloco4 & Bloco5 & Bloco6 & Bloco7 & Bloco8 & Bloco9 & Bloco10 & Bloco11 & Bloco12 \\
\hline $\mathbf{0}$ & 11 & 22 & 25 & 10 & 23 & 21 & 22 & 30 & 6 & 3 & 28 & 16 \\
\hline 1 & 19 & 19 & 16 & 29 & 19 & 16 & 18 & 8 & 29 & 33 & 14 & 5 \\
\hline$(0+1)$ & 30 & 41 & 41 & 39 & 42 & 37 & 40 & 38 & 35 & 36 & 42 & 21 \\
\hline 2 & 9 & 1 & 1 & 1 & 0 & 4 & 1 & 2 & 7 & 6 & 0 & 0 \\
\hline 3 & 3 & 0 & 0 & 2 & 0 & 1 & 1 & 2 & 0 & 0 & 0 & 21 \\
\hline$(2+3)$ & 12 & 1 & 1 & 3 & 0 & 5 & 2 & 4 & 7 & 6 & 0 & 21 \\
\hline \multirow[t]{2}{*}{ Total } & 42 & 42 & 42 & 42 & 42 & 42 & 42 & 42 & 42 & 42 & 42 & 42 \\
\hline & \multicolumn{12}{|c|}{ Tratamento antimicrobiano } \\
\hline Escore & Bloco1 & Bloco2 & Bloco3 & Bloco4 & Bloco5 & Bloco6 & Bloco7 & Bloco8 & Bloco9 & Bloco10 & Bloco11 & Bloco12 \\
\hline 0 & 8 & 29 & 11 & 6 & 14 & 26 & 28 & 39 & 6 & 10 & 16 & 10 \\
\hline 1 & 26 & 13 & 31 & 35 & 27 & 15 & 6 & 3 & 30 & 21 & 25 & 24 \\
\hline$(0+1)$ & 34 & 42 & 42 & 41 & 41 & 41 & 34 & 42 & 36 & 31 & 41 & 34 \\
\hline 2 & 5 & 0 & 0 & 1 & 0 & 1 & 8 & 0 & 4 & 11 & 1 & 7 \\
\hline 3 & 3 & 0 & 0 & 0 & 1 & 0 & 0 & 0 & 2 & 0 & 0 & 1 \\
\hline$(2+3)$ & 8 & 0 & 0 & 1 & 1 & 1 & 8 & 0 & 6 & 11 & 1 & 8 \\
\hline \multirow[t]{2}{*}{ Total } & 42 & 42 & 42 & 42 & 42 & 42 & 42 & 42 & 42 & 42 & 42 & 42 \\
\hline & \multicolumn{12}{|c|}{ Tratamento probiótico } \\
\hline Escore & Bloco1 & Bloco2 & Bloco3 & Bloco4 & Bloco5 & Bloco6 & Bloco7 & Bloco8 & Bloco9 & Bloco10 & Bloco11 & Bloco12 \\
\hline $\mathbf{0}$ & 12 & 18 & 19 & 6 & 37 & 25 & 38 & 23 & 15 & 5 & 26 & 8 \\
\hline 1 & 20 & 14 & 21 & 18 & 3 & 16 & 3 & 16 & 21 & 27 & 16 & 32 \\
\hline$(0+1)$ & 32 & 32 & 40 & 24 & 40 & 41 & 41 & 39 & 36 & 32 & 42 & 40 \\
\hline 2 & 7 & 5 & 2 & 18 & 0 & 1 & 1 & 3 & 4 & 9 & 0 & 1 \\
\hline 3 & 3 & 5 & 0 & 0 & 2 & 0 & 0 & 0 & 2 & 1 & 0 & 1 \\
\hline$(2+3)$ & 10 & 10 & 2 & 18 & 2 & 1 & 1 & 3 & 6 & 10 & 0 & 2 \\
\hline \multirow[t]{2}{*}{ Total } & 42 & 42 & 42 & 42 & 42 & 42 & 42 & 42 & 42 & 42 & 42 & 42 \\
\hline & \multicolumn{12}{|c|}{ Tratamento prebiótico } \\
\hline Escore & Bloco1 & Bloco2 & Bloco3 & Bloco4 & Bloco5 & Bloco6 & Bloco7 & Bloco8 & Bloco9 & Bloco10 & Bloco11 & Bloco12 \\
\hline $\mathbf{0}$ & 2 & 25 & 4 & 18 & 22 & 19 & 23 & 38 & 13 & 13 & 10 & 34 \\
\hline 1 & 5 & 13 & 31 & 23 & 18 & 23 & 17 & 4 & 25 & 27 & 25 & 8 \\
\hline$(0+1)$ & 7 & 38 & 35 & 41 & 40 & 42 & 40 & 42 & 38 & 40 & 35 & 42 \\
\hline 2 & 10 & 2 & 4 & 1 & 2 & 0 & 2 & 0 & 4 & 2 & 6 & 3 \\
\hline 3 & 25 & 2 & 3 & 0 & 0 & 0 & 0 & 0 & 0 & 0 & 1 & -3 \\
\hline$(2+3)$ & 35 & 4 & 7 & 1 & 2 & 0 & 2 & 0 & 4 & 2 & 7 & 0 \\
\hline \multirow[t]{2}{*}{ Total } & 42 & 42 & 42 & 42 & 42 & 42 & 42 & 42 & 42 & 42 & 42 & 42 \\
\hline & \multicolumn{12}{|c|}{ Tratamento extrato vegetal } \\
\hline Escore & Bloco1 & Bloco2 & Bloco3 & Bloco4 & Bloco5 & Bloco6 & Bloco7 & Bloco8 & Bloco9 & Bloco10 & Bloco11 & Bloco12 \\
\hline $\mathbf{0}$ & 17 & 7 & 11 & 24 & 37 & 31 & 34 & 30 & 4 & 14 & 20 & 3 \\
\hline 1 & 25 & 12 & 25 & 18 & 5 & 6 & 4 & 6 & 19 & 26 & 21 & 34 \\
\hline$(0+1)$ & 42 & 19 & 36 & 42 & 42 & 37 & 38 & 36 & 23 & 40 & 41 & 37 \\
\hline 2 & 0 & 5 & 4 & 0 & 0 & 2 & 1 & 4 & 16 & 2 & 1 & 5 \\
\hline 3 & 0 & 18 & 2 & 0 & 0 & 3 & 3 & 2 & 3 & 0 & 0 & 0 \\
\hline$(2+3)$ & 0 & 23 & 6 & 0 & 0 & 5 & 4 & 6 & 19 & 2 & 1 & 5 \\
\hline Total & 42 & 42 & 42 & 42 & 42 & 42 & 42 & 42 & 42 & 42 & 42 & 42 \\
\hline
\end{tabular}

Escores 0 e 1 são considerados casos normais

Escores 2 e 3 são considerados diarréia 
APÊNDICE 12. Totais de escores fecais por bloco, no período de um a 35 dias de experimentação (Experimento II)

\begin{tabular}{|c|c|c|c|c|c|c|c|c|c|c|c|c|}
\hline \multirow[b]{2}{*}{ Escore } & \multicolumn{12}{|c|}{ Tratamento controle } \\
\hline & Bloco1 & Bloco2 & Bloco3 & Bloco4 & Bloco5 & Bloco6 & Bloco7 & Bloco8 & Bloco9 & Bloco10 & Bloco11 & Bloco12 \\
\hline $\mathbf{0}$ & 25 & 45 & 53 & 31 & 34 & 33 & 33 & 37 & 14 & 10 & 44 & 26 \\
\hline 1 & 25 & 23 & 16 & 32 & 27 & 23 & 25 & 17 & 35 & 37 & 20 & 9 \\
\hline$(0+1)$ & 50 & 68 & 69 & 63 & 61 & 56 & 58 & 54 & 49 & 47 & 64 & 35 \\
\hline 2 & 13 & 2 & 1 & 4 & 5 & 10 & 3 & 7 & 17 & 19 & 3 & 4 \\
\hline 3 & 7 & 0 & 0 & 3 & 4 & 4 & 9 & 9 & 4 & 4 & 3 & 31 \\
\hline$(2+3)$ & 20 & 2 & 1 & 7 & 9 & 14 & 12 & 16 & 21 & 23 & 6 & 35 \\
\hline \multirow[t]{2}{*}{ Total } & 70 & 70 & 70 & 70 & 70 & 70 & 70 & 70 & 70 & 70 & 70 & 70 \\
\hline & \multicolumn{12}{|c|}{ Tratamento antimicrobiano } \\
\hline Escore & Bloco1 & Bloco2 & Bloco3 & Bloco4 & Bloco5 & Bloco6 & Bloco7 & Bloco8 & Bloco9 & Bloco10 & Bloco11 & Bloco12 \\
\hline 0 & 21 & 55 & 34 & 22 & 27 & 32 & 41 & 59 & 13 & 14 & 25 & 19 \\
\hline 1 & 31 & 15 & 34 & 41 & 38 & 22 & 19 & 5 & 38 & 26 & 37 & 29 \\
\hline$(0+1)$ & 52 & 70 & 68 & 63 & 65 & 54 & 60 & 64 & 51 & 40 & 62 & 48 \\
\hline 2 & 11 & 0 & 2 & 7 & 2 & 7 & 10 & 2 & 9 & 27 & 7 & 18 \\
\hline 3 & 7 & 0 & 0 & 0 & 3 & 9 & 0 & 4 & 10 & 3 & 1 & 4 \\
\hline$(2+3)$ & 18 & 0 & 2 & 7 & 5 & 16 & 10 & 6 & 19 & 30 & 8 & 22 \\
\hline \multirow[t]{2}{*}{ Total } & 70 & 70 & 70 & 70 & 70 & 70 & 70 & 70 & 70 & 70 & 70 & 70 \\
\hline & \multicolumn{12}{|c|}{ Tratamento probiótico } \\
\hline Escore & Bloco1 & Bloco2 & Bloco3 & Bloco4 & Bloco5 & Bloco6 & Bloco7 & Bloco8 & Bloco9 & Bloco10 & Bloco11 & Bloco12 \\
\hline $\mathbf{0}$ & 33 & 33 & 25 & 17 & 58 & 35 & 49 & 28 & 23 & 9 & 36 & 13 \\
\hline 1 & 25 & 21 & 28 & 24 & 7 & 27 & 10 & 27 & 27 & 37 & 30 & 48 \\
\hline$(0+1)$ & 58 & 54 & 53 & 41 & 65 & 62 & 59 & 55 & 50 & 46 & 66 & 61 \\
\hline 2 & 9 & 10 & 7 & 23 & 2 & 8 & 7 & 13 & 10 & 18 & 4 & 7 \\
\hline 3 & 3 & 6 & 10 & 6 & 3 & 0 & 4 & 2 & 10 & 6 & 0 & 2 \\
\hline$(2+3)$ & 12 & 16 & 17 & 29 & 5 & 8 & 11 & 15 & 20 & 24 & 4 & 9 \\
\hline \multirow[t]{2}{*}{ Total } & 70 & 70 & 70 & 70 & 70 & 70 & 70 & 70 & 70 & 70 & 70 & 70 \\
\hline & \multicolumn{12}{|c|}{ Tratamento prebiótico } \\
\hline Escore & Bloco1 & Bloco2 & Bloco3 & Bloco4 & Bloco5 & Bloco6 & Bloco7 & Bloco8 & Bloco9 & Bloco10 & Bloco11 & Bloco12 \\
\hline $\mathbf{0}$ & 15 & 42 & 24 & 28 & 35 & 31 & 41 & 59 & 21 & 20 & 17 & 48 \\
\hline 1 & 16 & 23 & 37 & 33 & 27 & 38 & 25 & 5 & 38 & 38 & 30 & 15 \\
\hline$(0+1)$ & 31 & 65 & 61 & 61 & 62 & 69 & 66 & 64 & 59 & 58 & 47 & 63 \\
\hline 2 & 12 & 3 & 5 & 2 & 5 & 1 & 4 & 2 & 9 & 8 & 18 & 7 \\
\hline 3 & 27 & 2 & 4 & 7 & 3 & 0 & 0 & 4 & 2 & 4 & 5 & 0 \\
\hline$(2+3)$ & 39 & 5 & 9 & 9 & 8 & 1 & 4 & 6 & 11 & 12 & 23 & 7 \\
\hline \multirow[t]{2}{*}{ Total } & 70 & 70 & 70 & 70 & 70 & 70 & 70 & 70 & 70 & 70 & 70 & 70 \\
\hline & \multicolumn{12}{|c|}{ Tratamento extrato vegetal } \\
\hline Escore & Bloco1 & Bloco2 & Bloco3 & Bloco4 & Bloco5 & Bloco6 & Bloco7 & Bloco8 & Bloco9 & Bloco10 & Bloco11 & Bloco12 \\
\hline $\mathbf{0}$ & 39 & 17 & 32 & 43 & 56 & 41 & 43 & 50 & 13 & 23 & 32 & 22 \\
\hline 1 & 31 & 13 & 28 & 21 & 12 & 9 & 8 & 11 & 29 & 38 & 27 & 39 \\
\hline$(0+1)$ & 70 & 30 & 60 & 64 & 68 & 50 & 51 & 61 & 42 & 61 & 59 & 61 \\
\hline 2 & 0 & 10 & 5 & 0 & 2 & 12 & 9 & 6 & 19 & 7 & 8 & 7 \\
\hline 3 & 0 & 30 & 5 & 6 & 0 & 8 & 10 & 3 & 9 & 2 & 3 & 2 \\
\hline$(2+3)$ & 0 & 40 & 10 & 6 & 2 & 20 & 19 & 9 & 28 & 9 & 11 & 9 \\
\hline Total & 70 & 70 & 70 & 70 & 70 & 70 & 70 & 70 & 70 & 70 & 70 & 70 \\
\hline
\end{tabular}

Escores 0 e 1 são considerados casos normais

Escores 2 e 3 são considerados diarréia 
APÊNDICE 13. Temperaturas máximas e mínimas registradas na primeira repetição, realizada no tempo, para o Experimento II

\begin{tabular}{|c|c|c|c|c|c|}
\hline Data & Mínima & Máxima & Data & Mínima & Máxima \\
\hline $10 / 10 / 02$ & --- & 31,5 & $28 / 10 / 02$ & 21,5 & 29,5 \\
\hline $11 / 10 / 02$ & 24,5 & 32,0 & $30 / 10 / 02$ & 21,5 & 33,5 \\
\hline $12 / 10 / 02$ & 25,0 & 31,0 & $31 / 10 / 02$ & 22,5 & 25,0 \\
\hline $13 / 10 / 02$ & 23,0 & 33,0 & $01 / 11 / 02$ & 22,5 & 26,0 \\
\hline $14 / 10 / 02$ & 23,0 & 33,5 & $02 / 11 / 02$ & 20,0 & 29,0 \\
\hline $15 / 10 / 02$ & 22,5 & 34,0 & $03 / 11 / 02$ & 19,5 & 30,0 \\
\hline $16 / 10 / 02$ & 19,0 & 34,0 & $04 / 11 / 02$ & 18,5 & 31,0 \\
\hline $17 / 10 / 02$ & 24,0 & 32,0 & $05 / 11 / 02$ & 21,0 & 27,0 \\
\hline $18 / 10 / 02$ & 23,0 & 30,0 & $06 / 11 / 02$ & 19,0 & 24,0 \\
\hline $19 / 10 / 02$ & 22,5 & 29,0 & $07 / 11 / 02$ & 18,0 & 19,0 \\
\hline $20 / 10 / 02$ & 22,5 & 33,0 & $08 / 11 / 02$ & 15,5 & 25,5 \\
\hline $21 / 10 / 02$ & 23,0 & 33,5 & $09 / 11 / 02$ & 16,0 & 27,5 \\
\hline $22 / 10 / 02$ & 22,0 & 28,0 & $10 / 11 / 02$ & 16,0 & 31,0 \\
\hline $23 / 10 / 02$ & 20,5 & 26,5 & $11 / 11 / 02$ & 17,0 & 31,0 \\
\hline $24 / 10 / 02$ & 19,5 & 30,0 & $12 / 11 / 02$ & 25,0 & 31,0 \\
\hline $25 / 10 / 02$ & 22,0 & 31,0 & $13 / 11 / 02$ & 21,0 & 32,0 \\
\hline $26 / 10 / 02$ & 22,0 & 30,0 & Média & 20,9 & 29,8 \\
\hline $27 / 10 / 02$ & 22,0 & 30,0 & D. Padrão & $\pm 2,5$ & $\pm 3,3$ \\
\hline
\end{tabular}


APÊNDICE 14. Temperaturas máximas e mínimas registradas na segunda repetição, realizada no tempo, para o Experimento II

\begin{tabular}{|c|c|c|c|c|c|}
\hline Data & Mínima & Máxima & Data & Mínima & Máxima \\
\hline $11 / 02 / 03$ & --- & 34,0 & $02 / 03 / 03$ & 21,0 & 33,0 \\
\hline $12 / 02 / 03$ & 22,5 & 34,0 & $03 / 03 / 03$ & 22,5 & 31,0 \\
\hline $13 / 02 / 03$ & 23,5 & 32,0 & $04 / 03 / 03$ & 24,0 & 32,0 \\
\hline $14 / 02 / 03$ & 23,0 & 27,0 & $05 / 03 / 03$ & 23,0 & 32,5 \\
\hline $15 / 02 / 03$ & 22,5 & 25,0 & $06 / 03 / 03$ & 22,0 & 31,0 \\
\hline $16 / 02 / 03$ & 23,0 & 29,0 & $07 / 03 / 03$ & 24,0 & 30,0 \\
\hline $17 / 02 / 03$ & 22,5 & 29,0 & $08 / 03 / 03$ & 22,5 & 25,0 \\
\hline $18 / 02 / 03$ & 22,5 & 26,5 & $09 / 03 / 03$ & 22,0 & 26,5 \\
\hline $19 / 02 / 03$ & 21,0 & 31,0 & $10 / 03 / 03$ & 23,0 & 26,0 \\
\hline $20 / 02 / 03$ & 23,5 & 31,0 & $11 / 03 / 03$ & 23,0 & 28,0 \\
\hline $21 / 02 / 03$ & 24,0 & 32,0 & $12 / 03 / 03$ & 24,0 & 28,5 \\
\hline $22 / 02 / 03$ & 24,0 & 32,0 & $13 / 03 / 03$ & 23,0 & 29,0 \\
\hline $23 / 02 / 03$ & 24,0 & 33,5 & $14 / 03 / 03$ & 21,5 & 30,0 \\
\hline $24 / 02 / 03$ & 22,0 & 32,5 & $15 / 03 / 03$ & 21,5 & 30,5 \\
\hline $25 / 02 / 03$ & 23,0 & 33,5 & $16 / 03 / 03$ & 22,5 & 32,0 \\
\hline $26 / 02 / 03$ & 24,0 & 33,5 & $17 / 03 / 03$ & 23,0 & 29,0 \\
\hline $27 / 02 / 03$ & 22,0 & 33,0 & $18 / 03 / 03$ & 23,0 & --- \\
\hline $28 / 02 / 03$ & 22,5 & 34,0 & Média & 22,73 & 30,57 \\
\hline $01 / 03 / 03$ & 21,0 & 33,5 & D. Padrão & 0,89 & 2,71 \\
\hline
\end{tabular}


APÊNDICE 15. Temperaturas máximas e mínimas registradas na terceira repetição, realizada no tempo, para o Experimento II

\begin{tabular}{|c|c|c|c|c|c|}
\hline Data & Mínima & Máxima & Data & Mínima & Máxima \\
\hline $25 / 03 / 03$ & 19,0 & 30,0 & $13 / 04 / 03$ & 21,0 & 28,5 \\
\hline $26 / 03 / 03$ & 22,5 & 27,5 & $14 / 04 / 03$ & 23,0 & 31,5 \\
\hline $27 / 03 / 03$ & 22,5 & 28,0 & $15 / 04 / 03$ & 19,5 & 31,0 \\
\hline $28 / 03 / 03$ & 21,0 & 28,0 & $16 / 04 / 03$ & 20,0 & 27,0 \\
\hline $29 / 03 / 03$ & 21,0 & 29,0 & $17 / 04 / 03$ & 18,5 & 29,0 \\
\hline $30 / 03 / 03$ & 21,5 & 29,5 & $18 / 04 / 03$ & 18,5 & 29,0 \\
\hline $31 / 03 / 03$ & 21,0 & 31,5 & $19 / 04 / 03$ & 18,5 & 29,0 \\
\hline $01 / 04 / 03$ & 24,0 & 31,0 & $20 / 04 / 03$ & 18,5 & 29,0 \\
\hline $02 / 04 / 03$ & 21,5 & 30,0 & $21 / 04 / 03$ & 18,5 & 32,5 \\
\hline $03 / 04 / 03$ & 20,0 & 30,0 & $22 / 04 / 03$ & 19,5 & 35,0 \\
\hline $04 / 04 / 03$ & 22,0 & 25,0 & $23 / 04 / 03$ & 21,5 & 36,0 \\
\hline $05 / 04 / 03$ & 21,0 & 25,5 & $24 / 04 / 03$ & 21,0 & 35,0 \\
\hline $06 / 04 / 03$ & 21,0 & 27,0 & $25 / 04 / 03$ & 20,0 & 34,5 \\
\hline $07 / 04 / 03$ & 21,0 & 26,5 & $26 / 04 / 03$ & 20,5 & 35,0 \\
\hline $08 / 04 / 03$ & 22,5 & 30,5 & $27 / 04 / 03$ & 21,0 & 36,0 \\
\hline $09 / 04 / 03$ & 19,5 & 28,5 & $28 / 04 / 03$ & 19,0 & 34,5 \\
\hline $10 / 04 / 03$ & 22,0 & 29,5 & $29 / 04 / 03$ & 20,0 & 33,0 \\
\hline $11 / 04 / 03$ & 21,5 & 27,5 & Média & 20,7 & 30,1 \\
\hline $12 / 04 / 03$ & 22,0 & 28,0 & $D$. Padrão & $\pm 1,42$ & $\pm 3,02$ \\
\hline
\end{tabular}

